\title{
"MOVIMENTO-IMAGEM-IDEIA":
}

\section{o percurso de uma prática}

\author{
(versão corrigida)
}

Dissertação apresentada à Escola de Comunicações e Artes da Universidade de São Paulo para obtenção do título de Mestre em Artes. Área de concentração: Teoria e Prática: Texto e Cena

Orientador: Prof. Dr. Antônio Carlos de Araújo Silva

\section{São Paulo}


Autorizo:

[ ] divulgação do texto completo em bases de dados especializadas.

[ ] reprodução total ou parcial, por processos fotocopiadores, exclusivamente para fins acadêmicos e científicos.

Assinatura:

Data:

Ficha Catalográfica

Vieira, Cristiane Paoli

"Movimento-imagem-ideia": o percurso de uma prática / Cristiane Paoli Vieira. - São Paulo : C. P. Vieira, 2016.

$103 \mathrm{p}$.

Dissertação (mestrado) - Escola de Comunicações e Artes/USP, 2016.

Bibliografia

O exemplar 1 não pode ser emprestado

Bibliotecas e sociedade

Memória e sociedade

Teses

$\mathrm{t}$ 
Nome do Autor: Cristiane Paoli Vieira

Título da Dissertação/Tese: "Movimento-imagem-ideia": o percurso de uma prática

Presidente da Banca: Prof. Dr. Antônio Carlos de Araújo Silva

Banca Examinadora:

Prof. Dr.

Instituição:

Prof. Dr.

Instituição:

Prof. Dr. Instituição:

Prof. Dr. Instituição:

Prof. Dr. Instituição:

Aprovada em:

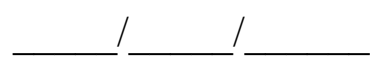


[VERSO EM BRANCO] 
Sou do empírico, sou intuitiva, sou das relações Estudo, trabalho, bebo do científico Retorno ao mundo o meu entendimento sobre as verdades recebidas Nos livros, dos pensadores, dos cientistas Vivo dos erros e dos acertos Adoro a antropofagia, pois de alguma forma ela me liberta Devolvo ao mundo a somatória de meus entendimentos Bebo da fonte e a devolvo diferente 
[VERSO EM BRANCO] 
À minha mãe e aos meus irmãos 
[VERSO EM BRANCO] 


\section{AGRADECIMENTOS}

Ao meu orientador, Professor Dr. Antônio Carlos de Araújo Silva, que me ofertou um caminho de escrita possível, me encorajando cada vez mais, sem deixar de me corrigir com delicadeza e liberdade.

À Professora Dra. Silvana Garcia e ao Professor Dr. Antônio Januzelli, pelos questionamentos inquietantes e profundos feitos na banca de qualificação e ao longo de minha trajetória.

A todos os intérpretes, colaboradores, da Cia. Nova Dança 4, da Troupe de Atmosfera Nômade e do espetáculo Ladies, da inocência à crueldade, que aqui representam outros intérpretes de outros espetáculos, os quais acreditaram em minhas proposições e me ajudaram a construir um percurso de pesquisa cênica.

Aos Professores da Escola de Arte Dramática - EAD-ECA-USP, por me incentivarem a realizar esse percurso de mestrado, pelo espaço investigativo e de criação.

Às minhas colegas de Pós-Graduação, Bel e Mônica, amigas atentas, sempre me ajudaram a seguir para a próxima etapa.

Às minhas sobrinhas, Bruna, Juliana, Flávia e Ana, amadas parceiras de vida, e às sobrinhas netas, Ana Lua e Maria Flor, que iluminam e enchem de amor e de alegria o meu viver. 
[VERSO EM BRANCO] 
VIEIRA, Cristiane Paoli. “Movimento-imagem-ideia”: o percurso de uma prática. São Paulo, 2016. 101 f. Dissertação (Mestrado em Ciências da Comunicação) - Escola de Comunicações e Artes, Universidade de São Paulo.

RESUMO: Esta dissertação tem como objeto de estudo a elaboração do conceito, "movimento-imagem-ideia", desenvolvido no percurso de uma prática de improvisação. Iniciada no teatro, por meio dos aprendizados do jogo teatral, do jogo das máscaras, como a commedia dell'arte e o palhaço, encontra a dança e as abordagens somáticas, ampliando-se e oferecendo estrutura à autonomia do intérprete improvisacional. As pesquisas cênicas que constituíram caminho e estabelecimento dessa conceituação, analisadas neste trabalho, têm por foco a improvisação e a máscara de A Troupe de Atmosfera Nômade; as improvisações em tempo real, diante do público, da Cia. Nova Dança 4; e a estrutura pré-fixada na dança, em Ladies, da inocência à crueldade, com possibilidades de rupturas improvisacionais.

Palavras-chave: "movimento-imagem-ideia", improvisação, dança teatro, máscaras, commedia dell'arte, palhaço, jogo de compêndio. 
[VERSO EM BRANCO] 
VIEIRA, Cristiane Paoli. "Movement-Image-Idea": the trajectory of a practice. São Paulo, 2016. 101 f. Dissertação (Mestrado em Ciências da Comunicação) - Escola de Comunicações e Artes, Universidade de São Paulo.

\begin{abstract}
ABSTRAC: This dissertation investigates the elaboration of a concept, "movementimage-idea", developed during an improvisation practice. When this improvisation which started in the theatre with the use of theatre games, mask games, such as commedia dell'arte and clowns - meets dance and somatic approaches, it is amplified, now offering structure to the autonomy of the improvisational actor. Previous research on performing arts that have paved a path to the establishment of the concept analyzed here focus on A Troupe de Atmosfera Nômade's use of improvisation and masks; Cia Nova Dança 4's real time improvisation in front of an audience; and the structure prefixed on dancing, in Ladies, from innocence to cruelty, with possible improvisational ruptures.
\end{abstract}

Key-words: "movement-image-idea", improvisation, dance-theatre, masks, commedia dell'arte, clown, compendium. 
[VERSO EM BRANCO] 


\section{SUMÁRIO}

Introdução

\section{Capítulo I}

Apreensão do vocabulário

\section{Capítulo II}

A Improvisação e a Máscara na Troupe de Atmosfera Nômade. .33

\section{Capítulo III}

Ponto de Mutação: O Encontro com a Dança 46

\section{Capítulo IV}

A Improvisação e a Dança na Cia. Nova Dança 4.

\section{Capítulo V}

Ponto de Suspensão: O Reencontro com a Estrutura Pré-Fixada 84

Considerações Finais. .97

Bibliografia 
[VERSO EM BRANCO] 


\title{
1. Introdução
}

\author{
QUEM SOU EU?
}

Quem sou eu, grita em mim

Essa pergunta não cessa

Por que estou aqui?

O que fiz, o que não fiz?

Os caminhos que escolhi, caminhos e pessoas que me escolheram

As nossas afinidades, pessoas variadas de mesmo pensamento e vontades

Mesmas energias ou energias que conversam entre si

Encontros, encontros com pessoas que confiaram em mim e vibraram comigo

A energia do fazer, do brincar, do descobrir, do falhar, do entregar

Do estar presente como uma dádiva

Como uma faísca de alegria, de juventude

Que delícia é nosso começo

Quanta confiança, quanta vontade e frustrações

Quantas ilusões, dificuldades e iluminações

Tudo quero colocar na dissertação

Mas o que é uma dissertação?

Produzir razões em favor da própria opinião

Oferecer um modo de pensar

Um saber

Pôr em discussão um discurso

Discurso que cada vez mais, a medida que tomo contato,

Me conduz a alguns mestres e a minha própria caminhada

Um discurso traduzido em corpos, em estética

Essas transmissões aconteceram também por outros mestres

Estes sim, encontros presenciais

Fui aluna de Antônio Januzelli, mestre de interpretação, de improvisação e de vida 
Meu primeiro professor

Comecei assim, improvisando

Se improvisar significa estar atento ao instante e dizer sim

Eu disse sim

Numa tarde na saída da Logos Escola de $2^{\circ}$ Grau

Eu já na rua

Uma colega de classe me perguntou:

- Você não vai fazer a aula de teatro?

Eu respondi:

- Como?

- Sim, teatro, vamos?

- Vamos!

Na sala, Janô ${ }^{1}$ nos convidou a falar

Era um exercício de exposição de chegada

Nos descolávamos das paredes e íamos ao centro contar por que estávamos ali

Disse uma verdade que nem eu sabia:

Como não cantava, não dançava

Não tocava nenhum instrumento, nem desenhava

Eu queria experimentar um modo de me expressar

O teatro

Sempre fui muito introspectiva e talvez essa forma de arte pudesse me ajudar

Ele nos deixou brincar, imaginar

Acredito que nos deixou jogar

Tenho até hoje muitas memórias em meu corpo dessas experiências vivenciadas

A memória do corpo é holística e permanece

Aprendi o poder da imaginação

O acender os olhos

O libertar o corpo

Ser eu mesma para poder imaginar ser outrem

De Janô recebi o chamado para ser íntegra ou para a integridade

\footnotetext{
${ }^{1}$ Professor Doutor Antônio Luiz Dias Januzelli, foi professor de improvisação da Escola de Arte Dramática/EAD/ECA/USP e do Departamento de Artes Cênicas/CAC/ECA/USP.
} 


\subsection{O Começo}

Com Janô, entendi que havia algo de muito vibrante em mim: a brincadeira, a alegria de fazer rir e rir de mim e dos outros. Percebi um pé na comicidade que nem de longe podia supor que fizesse parte do meu repertório pessoal (se bem que quando criança Os Três Patetas, Lucille de Ball, Chaplin, O Manda-Chuva, além de Arrelia e Piolin, fossem meus companheiros de universo infantil).

Minha alegria em fazer teatro era imensa. Os momentos dramáticos em laboratórios imaginativos eram prazerosos e intensos; eu sentia tudo, vivenciava com a inocência primordial de quem descobre a melhor das aventuras. Meu encontro com Janô e o teatro foi uma revolução pessoal. E sei que isso não aconteceu só comigo, aconteceu com outras pessoas que estavam naquele curso extracurricular de escola de segundo grau. Não era apenas deleite, era trabalho, era atrito, era investigação de nosso universo interno e externo. Janô nos falava de nossas liberações; nos provocava o pensamento, as ideias, a aceitação do corpo, (das vísceras aos líquidos), das relações; nos instigava à pesquisa desse SER/ATOR, jogando fora a falsa moral, mantendo o respeito ao outro, com escuta dos sins e nãos. Tudo isso, um aprendizado em estado puro, de curiosidade no olhar, de quem está começando a vida, descobrindo caminhos.

\subsection{Viver o Coletivo}

Depois do primeiro encontro no colegial, em 1977, tivemos um hiato. No início dos anos 1980, formamos um grupo de ex-alunos do Logos Escola de Segundo Grau e convidamos Janô para nos dirigir, nos orientar.

Um novo horizonte se abriu, reafirmando os princípios essenciais de sua pedagogia: o jogar, o brincar, o permitir-se, o arriscar, o estar presente, o relaxamento com vivacidade, os pés no chão; os eixos, os impulsos, as intenções, o foco, o centrarse; o dizer a verdade, o fazer de conta, a discussão sobre o ser humano e, acima de tudo, o princípio norteador de toda brincadeira saudável - a improvisação. Uso essas referências de forma consciente em meus processos pedagógicos ou de criação, mas às 
vezes elas aparecem como uma segunda natureza, por conta da apropriação de todas essas vivências.

A experiência em grupo orientada por ele, na qual o foco é o trabalho e não apenas o prazer das afinidades, traz a busca profunda do que comunicar juntos.

[...] encontro de um grupo só é selado quando há a descoberta de profundas raízes entre seus componentes e entre esses e as coisas que juntos vão expressar [...]. O crescimento grupal é resultado direto da confiança que um deposita no outro. Leva tempo para se desenvolver confiança [...]. (JANÔ, 1992, p. 38)

Durante o desenvolvimento da peça feita sob sua direção, eu tomava a frente por pura curiosidade e deleite; me arvorava em compreender as resoluções de luz e da espacialidade, produzia, ia atrás das burocracias e de outros detalhes, com a ajuda de meus parceiros. Queria me envolver ou aprender todos os meandros. Jamais imaginei ser diretora de teatro ou ter outra função nessa área.

O texto que nos inspirava era Seis Personagens a Procura de um Autor, de Pirandello. Aliás, esse texto foi inspiração para diversas criações coletivas ou processos colaborativos de espetáculos que realizei. Um texto que coloca em xeque muitas questões do nosso fazer teatral. A peça que fazíamos era Estilhaços, assinada como texto final de Jorge Miguel Marinho. A entrega cênica era farta, principalmente nos ensaios, nos jogos. O grupo era intenso, tentando resolver suas questões, disputas. E a maioria delas era resolvida pelo grupo, mediadas por Janô. Ele estimulava o grupo a ir em direção aos seus ajustes, sem medo das discussões ou dos confrontos. Éramos jovens, certamente imaturos, mas com muita energia e vontade de ir para a cena. As vaidades, às vezes, vinham à tona e o aprendizado era dar conta dessas verdades em nós e não as ignorá, jogando para debaixo do tapete. Esses embates se davam em roda, tanto para as resoluções de problemas, como para se falar dos caminhos a serem percorridos, ou mesmo festejar um bom ensaio.

O sentar em roda, o compartilhar sentimentos e ideias, as discussões, a resolução de atritos, a observação de cada indivíduo, o respeito à sua natureza, a busca por libertar a verdade de cada um, deixando o tempo de cada ser fluir, tudo isso é exatamente minha prática até hoje em sala de aula e nos grupos com que trabalho. Acredito que devemos conversar sobre tudo, não deixar nada para trás. Quando deixamos algo por dizer ou esclarecer, ou quando acontece o "silêncio barulhento" de brigas interiores, nossas relações podem se corroer e corroer o que há de melhor em nós. 
Vivemos em coletivo e aprender essa prática é, às vezes, a tarefa mais difícil.

Essas referências estão impregnadas na maneira como me relaciono ao orientar, dirigir alunos, atores, bailarinos, intérpretes, intérpretes-criadores; de explorar ideias, textos, signos, espaços; do meu olhar para o teatro, a dança, o circo, os bonecos, as artes cênicas. 


\section{Capítulo I - Apreensão do vocabulário}

\subsection{O Jogo e a Presença}

O jogo é um elemento presente em todas as fontes de desenvolvimento de minha criação, cuja convocação se dá por meio do estabelecimento de relações, sejam elas com o espaço, as pessoas, o texto, a música, os objetos ou a plateia. "Jogos são estruturas abertas, delimitadas por regras que definem o campo de atuação" (KOUDELA, 2010, p. 89). O gosto pela brincadeira, pelos jogos lúdicos ou mesmo os pelos jogos competitivos infantis ou esportivos sempre esteve presente em minhas salas de ensaios, treinamentos, aulas e espetáculos, com o objetivo de incitar o prazer de estar presente.

Sempre adorei jogar, brincar. Sou a caçula de três irmãos, que brincavam de esconde-esconde, jogar bola, andar a cavalo (férias no sítio de meus avós). Para fazer parte, deveria sempre me superar, então treinava muito, dava atenção aos detalhes, mesmo sendo no mínimo três anos mais nova. Perdia sempre, mas dava trabalho. Aprendi a me frustrar, a fracassar e às vezes a ganhar. Como era a única menina, também brincava muito sozinha; aprendi a ter a imaginação e o faz de conta como bons companheiros.

Carrego até os dias de hoje, valores intrínsecos que aprendi desde a primeira infância estudando em uma escola que aplicava a metodologia de Maria Montessori. Essa pedagogia, muito em moda nos anos 1960, procura observar a natureza da criança, deixando que, em seu tempo e ritmo, sua evolução aconteça, conforme sua necessidade de absorção do mundo à sua volta.

Quando chegávamos à escola, tínhamos o que chamavam de 'permanência', um período de mais ou menos uma hora para completarmos lição ou irmos à biblioteca, ou nos interessarmos por alguma outra atividade dentro da sala de aula. Muitas vezes, eu escolhia ficar contemplando pela janela uma árvore enorme e um jardim de verde bastante intenso. Talvez a minha atividade em boa parte dessa 'permanência' fosse dedicada à contemplação.

Sempre havia conversas em roda, com a classe sentada numa linha circular 
desenhada no chão, onde contávamos a vida e resolvíamos questões do dia a dia. Quando criança, tive muita liberdade para brincar e jogar. Levar essa vivência para o teatro, na vida adulta, foi um caminho natural, intuitivo. Sempre notei que a superação dos limites e das regras do jogo, por meio da diversão, favoreciam a prontidão, ampliando a disponibilidade e a potência ${ }^{2}$ de cada um. O jogador torna-se vivo, presente.

Philippe Gaulier, em seu livro O Atormentador: minhas ideias sobre teatro, declara:

\begin{abstract}
Quando palestrei sobre "o jogo", não me referia a uma tática que um burguesinho utiliza contra o outro, por exemplo, para extorquir-lhe dinheiro. Eu me referia ao movimento da natureza que explode para todos os lados, para além da Ilha de Páscoa. Você já viu os cavalos selvagens que brincam no campo perto de Brisbaine, na Austrália? Já viu como eles galopam até morrerem de sede, saltam uns sobre os outros, trepam, relincham de prazer? Eles brincam! Os gatos, os cães, os macacos, todos brincam para descobrir a vida, a natureza, o sexo, a luz. (GAULIER, 2016, p. 29)
\end{abstract}

A Presença faz-se pelo impulso de vida, é a natureza em nós. E conforme preconiza Gaulier em seus cursos de formação, a vivacidade e o brilho no olhar em cena possuem uma profunda importância. Por meio do jogo e da brincadeira, chega-se "a uma imensa pulsão de vida, um impulso vertiginoso, o primeiro sopro. Isso nos deixa descabelados" (GAULIER, 2016, p. 29).

A busca por esse impulso de vida é também proposta por Grotowski. Empregando outros caminhos e dispositivos, ele procura no ator "aquela linha de impulsos vivos, aqueles impulsos quase invisíveis, que tornam o ator irradiante" (GROTOWSKI, 2010, p. 169). A compreensão de que o corpo é memória, de que a espontaneidade é o fluxo de movimento e de que a precisão é a forma, tudo isso são conteúdos que servirão de trilha para muitas de minhas descobertas, marcadas igualmente por uma série de inspirações e de treinamentos, como a meditação, a ideia da coluna vertebral enquanto existência de vida, o impulso do gesto, da voz e das intensidades da vida no corpo.

As duas influências, Grotowski e Gaulier, entre outras, convergem de forma complementar em meu processo de apropriação dos procedimentos do teatro, da dança,

\footnotetext{
2 “Toda potência é ato, ativa, e em ato" (DELEUZE, 2002, p. 103).

"A potência do homem, enquanto se explica pela sua essência atual, é uma parte da potência infinita de Deus ou da Natureza (IV,4)” (DELEUZE, 2002, p. 104).
} 
da dança-teatro e da improvisação. Grotowski chegou até mim pelas mãos de Antônio Januzelli, durante a realização de um grupo de estudos a respeito do livro Em Busca de um Teatro Pobre, obra que muito nos contagiava pela proposta de primazia dos corpos dos atores. Representava a essência do fazer teatral, em que o treinamento intenso e a disciplina eram os caminhos efetivos para, por meio da corporeidade, chegar ao impulso puro e imaterial e, portanto, à instauração da presença cênica.

\subsection{A Commedia dell'arte, o Roteiro e Meierhold}

A commedia dell'arte atravessou meu caminho estruturando novas relações diante do jogo, da construção de personagens, do tipo de treinamento físico, da relação com o texto e do aprendizado de criação de um roteiro de ações, o chamado canovaccio. Afora a quebra da quarta parede, que transformou por completo meu entendimento do jogo com a plateia por meio da "triangulação".

No ano de 1985, fui convidada pelo diretor italiano Francesco Zigrino, que veio ao Brasil a convite da Escola de Arte Dramática, para participar da realização de uma montagem de commedia dell'arte. No elenco, éramos apenas mulheres fazendo todos os papéis, como uma referência e contraposição aos primórdios da commedia dell'arte, em que apenas homens podiam fazer parte. ${ }^{3} \mathrm{O}$ estudo do corpo com técnicas acrobáticas foi exaustivamente estimulado, pois as máscaras requerem corpos ágeis, bem desenhados e com posturas e movimentos exatos, conforme os relevos esculpidos nas próprias máscaras. As máscaras são tipos fixos ${ }^{4}$ que possuem comportamento, gestos, maneira de falar e atitudes pré-estabelecidas. Minha percepção e compreensão das experimentações que fazíamos de todas as máscaras me fizeram ver que elas nos oferecem uma lógica de construção das relações que permite que o jogo improvisacional aconteça com força imaginativa. A máscara, o tipo fixo, por exemplo, um Arlequim, não é dependente de um texto pré-articulado, e sim das relações que estabelece com as outras máscaras, situações e circunstâncias as quais está exposto para reagir.

\footnotetext{
${ }^{3}$ Os papéis eram, sumariamente: o velho, o criado, o namorado, segundo os esquemas da commedia clássica renascentista, mas também, e sobretudo, as atuações se davam com notável liberdade, especialmente no primeiro período do profissionalismo teatral, quando a presença da tradição bufonesca era mais marcada e as mulheres ainda não haviam entrado em cena (os homens seguiam representando os papéis femininos) (SCALA, 2003, p. 30).

${ }^{4}$ Arlecchino, Briguela, Pantalone, Doutore, Capitano, Fracesccina, Tartaglia, entre outros, e os Enamorados (estes não fazem uso da máscara para a construção do tipo).
} 
O jogo improvisacional na commedia dell'arte ocorria na medida em que nós, intérpretes, íamos nos apossando do repertório de cada máscara, ou do tipo fixo que nos cabia, somando a isso nossas características, trejeitos ou mesmo truques que cada uma pudesse acrescentar ao personagem, criando, assim, um vocabulário individual que oferecia à máscara originalidade, sem sair de suas características principais.

Muitos jogos foram propostos, e um deles, que se chamava "Cadema", nos preparou para uma escuta precisa no jogo das máscaras. Ele consiste em observar que, quando duas máscaras estão em cena, uma fala e a outra escuta. E quando uma se move, a outra entra em pausa. Outras variações também podiam acontecer, por exemplo: se uma máscara se mexer e não falar, a outra pode falar e não se mover. Ou seja, as duas máscaras não podem falar ou se mover ao mesmo tempo. Esse tipo de jogo oferece limpeza e consciência do tempo do outro no improvisar e faz transparecer a vivacidade da relação entre os jogadores/máscaras. A plateia é parte do jogo ao aplaudir e encorajar o jogador que estiver fluindo, concedendo-lhe, assim, o direito de continuar falando ou se movendo. Isso faz com que o intérprete, ao improvisar por meio do jogo de máscaras, comece a escutar a plateia e a perceber como ele está se desenvolvendo em cena, também em relação ao espectador.

A percepção da plateia no jogo das máscaras é bastante relevante. Tanto assim, que a máscara da commedia trabalha no frontal em relação à plateia, ou no máximo em três quartos em relação a ela. Jamais de costas ou de lado, pois se perde o desenho da máscara e sua magia. Há ainda o mecanismo da "triangulação", que prevê que a fala ou a atuação de uma máscara sejam feitas em posição frontal ao público e que todas as outras máscaras que estiverem em cena devem voltar seus olhares a ela. Ao terminar sua fala ou atuação, ela vira-se para outra máscara, transferindo-lhe o foco. A outra máscara, portanto, se posicionará frontalmente em relação ao espectador e todas as demais máscaras se voltarão para ela. Portanto, a "triangulação" é também um jogo, no qual reside o ritmo e a dinâmica das relações entre as personagens e a plateia, revelando comicidade e cumplicidade.

Depois do treinamento do corpo, das acrobacias, do estudo das máscaras, da apropriação dos tipos fixos, da criação de repertório próprio, do exercício dos jogos e das relações, veio o trabalho com o roteiro - o canovaccio. Zigrino apresentou-nos um canovaccio de Flaminio Scala, ${ }^{5}$ O Arranca Dentes. Tratava-se de um roteiro de ações

\footnotetext{
${ }^{5}$ Flaminio Scala (1547-1624): ator, dramaturgo, perfumista, diretor teatral (SCALA, 2003, p. 38).
} 
com uma estrutura de começo, meio e fim, em que havia as apresentações das personagens, os estabelecimentos das relações entre elas, o clímax, seu desenvolvimento e sua dissolução. Continha também outras interferências de encenação e dava espaço a muita invenção, não só pela própria natureza do canovaccio, como também pelo fato de que a cópia trazia alguns trechos com difícil leitura, muito provavelmente pela ação do tempo no original.

No livro de Faminio Scala, A Loucura de Isabella e outras Comédias da Commedia dell'arte, organizado e traduzido por Roberta Barni, que fez parte de nossa montagem como assistente de Zigrino, há referência de que os canovaccios de Scala não são simples roteiros de ações, pois são mais abertos na medida em que trazem outras indicações sobre o que deve ir à cena:

\begin{abstract}
Em seu Il Teatro delle Favole Rappresentative, Flamínio Scala não redige por extenso o texto das comédias, com falas e rubricas, como se costumava fazer: vale-se, ao contrário, da forma do "cenário", ou canovaccio. Abre cada fábula com um "argumento" que condensa a ação e o contexto anterior à ação cênica; enumera personagens e "coisas" necessárias à encenação, menciona o lugar geográfico da ação. Depois, passa a descrevê-la, inserindo, vez ou outra, no corpo do texto, elementos que são, claramente, "notas de direção" ou explicitações de "exibição de repertório". Raras vezes encontramos alguma fala (sumária) de um ou outro personagem. (apud SCALA, 2003, p. $41)^{6}$
\end{abstract}

Com essas indicações de cena, começamos a improvisar e a jogar com nossos repertórios. O roteiro, em geral, trazia cenas de duplas e trios, e raramente tinha cenas coletivas a não ser ao final, quando todas estavam em cena. Íamos assimilando as melhores falas e cenas para chegar ao fechamento e à estruturação da história a ser levada ao palco. Era nossa escrita cênica somada à da direção. A dramaturgia cênica é a escritura de uma peça de commedia dell'arte. E, apesar de fixar cenas e falas, coreografar cada cena com rigor, ritmo, tempo e dinâmica, e trabalhar a comunicação da triangulação, do gesto e da fala para obter um produto final fechado, o que percebíamos é que as personagens eram livres para brincar e jogar em diversas situações. Tinham vida própria e eram muito divertidas. Sabíamos muito bem quem era quem dentro do jogo e as linhas de raciocínio de cada máscara.

\footnotetext{
6 "Canovaccio é mais que um roteiro de ações. É reunião de ações, imagens, metáforas, intenções, conceitos, climas e intensidades que se pretende no espetáculo" (ABREU, 2004, p. 38).
} 
A commedia dell'arte influenciou muitos encenadores do século XX. "A formação de seus atores tornou-se modelo de um teatro, completo, baseado no ator e no coletivo, descobrindo o poder do gesto e da improvisação" (PAVIS, 1999, p. 62). Meierhold foi um deles, que, mesmo sendo inovador, dialogava com a tradição e com as convenções. Ele acredita que o espectador é tão importante quanto o ator no jogo teatral. E que o espectador deve resolver um enigma, ser arrebatado pela perfeição com que o ator domina sua arte, seu corpo e sua voz, que, para Meierhold, é a expressão da alma. Seu teatro é plástico, cheio de linhas, movimentos e cor. O humor se faz presente na relação, no jogo e nos desenhos dos corpos. Ele cria a biomecânica, que confere flexibilidade aos atores, assim como ritmo aos gestos, e fluidez ao espaço cênico, oferecendo dinâmicas ao coletivo, ao coro e articulando teatralidade.

Meierhold é polifônico, tem a interlocução como atitude artística e acredita que as artes devam se relacionar. É um encenador que valoriza o texto. Gérard Abensour,_no livro Vsévolod Meirhold ou a Invenção da Encenação (2011, p. 628), ao fazer a defesa de que a "arte da direção dos atores está subordinada ao valor literário do texto", citado em Meierhold, afirma: "Um axioma atravessa toda a sua vida: ' $O$ teatro nasce da literatura', mesmo durante seu período construtivista, que poderia tê-lo conduzido à rejeição do texto escrito, ele se impõe uma fidelidade absoluta a este último".

A música tem papel essencial e traduz tempo e ritmo na encenação de Meierhold, revelando-se parte integrante dela. Ele faz uso dos clássicos, assim como pede a músicos contemporâneos composições exclusivas; e as integra como personagem à encenação. Meierhold leva o jazz para a Rússia, o que acaba sendo para ele uma inspiração de estrutura de roteiro para improvisação. Ele navegava pelas interfaces das artes.

Meu primeiro contato com a obra de Meierhold foi nos anos 1990, por meio da diretora e prof. Dra. Maria Thais Santos Lima. Na época, ela pesquisava os movimentos da biomecânica e convidou a mim e aos atores da Troupe de Atmosfera Nômade, da qual eu fazia parte e era diretora, para participar de sua investigação prática. A experiência nos levou a utilizar, durante algum tempo, os movimentos da biomecânica como treinamento. A lógica dos movimentos, a sucessão de imagens, a relação rítmica e as contradições do corpo que a biomecânica oferece, trazendo presença e potência cênica, ficaram impregnadas em minha experiência. Assim como muitos aspectos de sua encenação, fazem eco até hoje em minha maneira de encenar. No ano de 2003, realizei montagem de $O$ Inspetor Geral, de Gógol, na Escola de Arte Dramática- 
EAD/ECA-USP, em que a inspiração e o objeto de estudo foi a histórica montagem de Meirehold sobre o mesmo texto. Sua herança é compartilhada por todos aqueles que compreendem que o teatro deve passar pelo domínio do corpo e pela sua evolução em face de outros corpos, como na dança (ABENSOUR, 2011, p. 11).

\subsection{O Palhaço}

O palhaço, ou clown, é também uma máscara. O nariz vermelho pode ou não estar no rosto daquele que joga, com as características do palhaço. Nas máscaras, em geral, a ponta do nariz é bastante importante, porque é ela que indica o olhar, para onde a máscara olha e para onde a plateia deve dirigir seu olhar, como se ela oferecesse o foco. O corpo do ator deve estar disponível para os traçados que a ponta do nariz risca no espaço, e, para isso, ele precisa das contradições do corpo.

Aprendi o clown pelas mãos de Philippe Gaulier, no ano de 1989, em Paris. Ele nos ensina que o clown é um ser livre, vulnerável, inadequado e idiota, que olha o mundo sempre como se fosse a primeira vez e que faz qualquer coisa para ser amado pela plateia. "Sua imbecilidade humana provoca riso" (GAULIER, 2016, p. 162). O palhaço critica o humano através de si mesmo, e não tem consciência da crítica que faz, ela apenas acontece. É um ser ingênuo, porém, Philippe Gaulier, em $O$ Atormentador: minhas ideias sobre teatro, adverte:

\footnotetext{
O público admira o prazer, a estratégia, a fantasia da qual o clown se serve para convencê-lo de alguma coisa. O público não está preocupado em saber se o negócio é verdadeiro ou falso. O que ele admira é a ingenuidade que é definida pelo dicionário como uma simplicidade, uma graça natural emprestada da confiança e da sinceridade. A ingenuidade da qual estou falando não tem nada a ver com aquela desprezível falsa ingenuidade de que se enfeitam os artistas de rua quando desfilam seus personagenzinhos, bonzinhos, assexuados, puros, bestinhas, que ficam pedindo um trocado. Essa ingenuidade é feia. Ela transforma o artista numa coisinha de nada. A ingenuidade é algo livre como o vento (GAULIER, 2016, p. 160).
}

O corpo do palhaço é um corpo vivo, que tem destreza, virtuose e, à sua maneira, graça. Tem seu próprio jeito de andar, de gesticular e de falar. Está pronto para tudo e sabe tudo, sem saber nada. O seu sucesso é o seu fracasso. Ele vive no erro, mas seu erro pode ser um acerto. O palhaço deve aceitar ser ridículo, divertir-se com isso e deleitar-se, fazendo com que, por meio de seu ridículo, ele possa trazer o riso, a 
gargalhada, a emoção e o encantamento à plateia. Quem joga com o palhaço deve ter o prazer de se desvencilhar de valores caros à sociedade, pois ele vai justamente na contramão de tais ideais.

O palhaço é um errante, que vem de lugar algum e vai para lugar nenhum. Não tem passado nem futuro, vive no aqui e agora. Federico Felini, em Felini por Felini, registra: "O clown representa uma situação de desnível, de inadequação do homem frente à vida. Através dele exorcizamos a nossa impotência, as nossas contradições e, principalmente, a luta ridícula e desproporcional contra os fantasmas de nosso egoísmo, de nossa vaidade e de nossa ilusão" (1986, p. 18).

Muitos palhaços são verdadeiros dançarinos, porém, como todo ator, seja ele trágico, melodramático, ou ator de commedia dell'arte, precisa das pausas. Ou, como diz Gaulier, precisa do "ponto fixo", um instante de silêncio do corpo para a escuta de seu entorno. O humor pode nascer de um ponto fixo, e a imobilidade não mata $\mathrm{o}$ impulso. Mas, para isso, é preciso a manutenção do prazer, do brilho do bem viver, diz Gaulier (2016, p. 40 e 43). As pausas fortalecem os desenhos do corpo, a corporeidade, e auxiliam na relação com o parceiro de cena - que é sempre o melhor parceiro, seja quem ele for - e no jogo com a plateia. A cumplicidade é essencial, e é preciso dizer sim (ao jogo) mesmo dizendo não (na cena). Há que se ter porosidade, abertura para guinadas da cena, pois seu mundo não é cartesiano, mas cheio de surpresas. Como aponta Renato Ferracini em $A$ arte de não interpretar como poesia corpórea do ator:

O clown improvisa porque deve estar aberto para a relação. Mesmo as esquetes e gags previamente construídas não são extremamente codificadas, fechadas; sempre existe um espaço para que o clown possa introduzir pequenas variações, de acordo com a relação do público. Ele improvisa com suas ações codificadas, seguindo seu estado orgânico e sua lógica. (2001, p. 220)

Como podemos perceber, o palhaço e a commedia dell'arte têm muitos pontos em comum: a corporeidade, seus desenhos corporais bem delineados, a relação com a máscara ou a ponta do nariz, a diversão, o cômico, o jogo e o estabelecimento das relações. Da mesma forma, a intensa relação com a plateia, a quebra da quarta parede, a comunicação direta e frontal com o espectador. Visto que são máscaras, triangulam e estabelecem cumplicidade. Porém, são universos distintos, que até convivem, mas não são da mesma família. São criações de lógicas diferentes. E mesmo que prescindam do texto para existir, realizam seu contexto de formas diversas. São improvisacionais, pois 
nascem antes do texto e se constroem no jogo relacional e, então, ficam disponíveis à realização da dramaturgia cênica.

O aprendizado e a vivência dessas experiências me conduziram ao entendimento e à apropriação dessas linguagens e técnicas; que, por sua vez, me fizeram seguir experimentando e pesquisando em sala de ensaio, e descobrindo modos próprios de criar a partir do que recebi.

\title{
2.4 Considerações e outros olhares sobre a Improvisação
}

Ao longo de minhas realizações, em alguns espetáculos, a improvisação tinha o papel de desencadear cenas a serem fixadas para uma peça de "resultado formalizado". Esse foi o caso, por exemplo, de Uma Rapsódia de Personagens Extravagantes, de 1991, peça que propunha o encontro entre as máscaras da commedia dell'arte e a do palhaço: duas modalidades de máscaras bastante afeitas à improvisação, que instituem regras e maneiras diferentes de construção da cena, de personagens, ações e texto, além de provocar um diálogo improvisacional muito rico. Além disso, é o resultado "fechado" desse processo que se apresenta para o público em forma de espetáculo.

Sandra Chacra, em seu livro Natureza e Sentido da Improvisação, nos revela:

\begin{abstract}
A natureza momentânea do teatro já prefigura, por si só, um caráter improvisacional na obra acabada. Por mais preparado, ensaiado e pronto, o teatro no seu grau máximo de cristalização - embora passível de reprodução - ainda assim ele não é capaz de se repetir exata e identicamente do mesmo jeito, por causa do seu fenômeno, cujo modo de ser é a comunicação momentânea, "quente", ao vivo, e cuja efemeridade leva a um efeito estético também transitório $(2005$, p. 15).
\end{abstract}

Em outros casos, a improvisação acontece no momento da apresentação ao público. Essas improvisações podem ser livres ou temáticas, com ou sem palavras, inspiradas em textos filosóficos ou dramaturgias clássicas, com ou sem música, apresentadas em teatros ou espaços alternativos. Essa tem sido a experiência com a Cia. Nova Dança 4, que tem como foco e objetivo principal a pesquisa da improvisação cênica em tempo real.

A necessidade de improvisar de modo mais radical, diante do público, acredito ter nascido da intenção de tornar mais autônoma a relação de criação do intérprete e de 
levar ao público o frescor dessas criações. Como diretora, sempre me senti privilegiada por vivenciar ensaios criativos e inusitados, sempre em busca da plenitude da primeira vez. O conviver com as máscaras de commedia dell'arte e do palhaço - elementos cuja existência prescinde de um texto ou de uma peça e que jogam com regras claras e construções de personagens com características fixas - me trouxe um entendimento pedagógico de suas composições, assim como compreensão da liberdade que esse universo tem na improvisação. Todos sabemos que a improvisação existe desde sempre, mas que ganha relevância no contexto da commedia dell'arte. Ainda em Sandra Chacra (2005, p. 30) a explicação: “Com a commedia dell'arte, aparece uma organização de atores especializados, graças a uma preparação técnica, mímica, vocal, coreográfica, acrobática, e também, com frequência, uma preparação cultural. Havia alguns que falavam diversas línguas e eram músicos consumados". Ou seja, eram intérpretes preparados, que possuíam excelência no ofício e, assim, a capacidade de, ao improvisar, criar ao mesmo tempo o espetáculo, diante do público, a cada apresentação. Essas características que os intérpretes deveriam ter, somadas ao canovaccio, foram informações valiosas que, articuladas a outras linguagens, me abriram caminhos dentro do improviso.

Existem alguns métodos improvisacionais que estão pautados na espontaneidade, na criatividade e nos processos criativos de teatro e de dança. Um deles, no campo do teatro, é a Impro. Trata-se de um trabalho desenvolvido por Keith Johnstone, centrado em jogos, e que, segundo Mariana Lima Muniz e Diogo Horta (2013, p. 3),

[...] é, em linhas gerais, uma técnica de desbloqueio da criatividade a partir da aceitação do erro e do fracasso como condições inerentes à criação. A Impro, nome dado aos espetáculos de improvisação e o sistema de treinamento de improvisadores, permite que os atores se coloquem diante do outro sem acordos prévios, no calor da ação, a fim de criar uma cena improvisada com narrativa, personagens, relação e etc., e que desperte e mantenha o interesse da plateia.

Johnstone criou o Teatro-Esporte, que tem por objetivo, como Vera Achaktin (2010) expõe, estabelecer uma partida de teatro em que dois times de atores se enfrentam no palco na arte de improvisar. Dessa forma, o Teatro-Esporte faz com que o público seja simultaneamente coautor e testemunha de um processo de criação, participando de todas as suas etapas, entre os acertos e erros e as dúvidas e certezas que a realização de todo desafio compreende (ACHAKTIN, 2010, p. 16). 
Diante desses aspectos gerais, os objetivos preparatórios (ou pré-espetáculo) propostos por Johnstone têm alguma semelhança com meus caminhos improvisacionais. Porém, o espetáculo que ele leva à cena pressupõe a disputa entre dois núcleos de jogadores estimulados pela plateia, sugerindo e participando ativamente da construção do espetáculo. Ao passo que os espetáculos improvisacionais que enceno fluem nas convenções teatrais ou de dança, aceitando os erros e os acertos factíveis do improvisar, mas ao mesmo tempo buscando que o espectador tenha a ilusão de ver algo acabado e preciso, com a emoção de ver o jogo sem que ele seja explícito. Sem dúvida alguma, a plateia também participa dessa construção, às vezes de maneira mais contemplativa e, em outros momentos, deixando fluir seu desejo de participar, principalmente nos trabalhos que são realizados em espaços não convencionais.

O Viewpoints, método desenvolvido pela diretora norte-americana Anne Bogart, tem o espaço e o tempo como temas de investigação. Esta é realizada por meio da improvisação e da composição corporal e vocal. Para tanto, Bogart trabalha com os elementos físicos da relação espacial, da resposta sinestésica, da forma, do gesto, da repetição, da arquitetura, do tempo, da duração e da topografia. No que diz respeito aos elementos vocais, ela focaliza o volume, a dinâmica, o andamento, a aceleração e a desaceleração, o timbre e o silêncio. Em sua metodologia, não existe hierarquia entre a voz e o corpo, assim como entre o texto e o movimento.

É muito impressionante a semelhança entre o trabalho que desenvolvi junto à Cia. Nova Dança 4 e as propostas de Anne Bogart, sem que eu tivesse conhecimento prévio sobre seu método. 


\title{
3. Capítulo II - A Improvisação e a Máscara na Troupe de Atmosfera Nômade
}

\author{
Penso na arte como busca do imaterial \\ Está além do corpo e das palavras \\ Pode estar nas emoções, nas sensações, nas intenções \\ No não dito, na penumbra, no silêncio \\ Nos mistérios da cena.
}

Tenho muitas experiências em grupo e companhias, aglutinadas a partir de um curso ou uma ideia. Mesmo que seja apenas a realização de um único trabalho, a dimensão do coletivo estruturado é dinâmica e as relações se intensificam. Raramente trabalho em produções de elenco formados para fazer uma peça ou realizo audições.

Em todos os grupos com que trabalhei, os altos e baixos sempre estiveram presentes. É quase uma natureza intrínseca dos processos, tanto na relação de arte como nas relações interpessoais. O convívio é sempre muito delicado e seu aprendizado valioso.

O elenco original da Troupe de Atmosfera Nômade era composto por dois núcleos de trajetórias distintas com quem eu havia trabalhado nos anos 1980. Alguns haviam estudado na Escola de Arte Dramática da Escola de Comunicações e Artes da Universidade de São Paulo (EAD/ECA-USP) ou passado por ela e outros faziam teatro independente. Éramos quatorze pessoas: André Pink, Attilio Cezar Prade ${ }^{7}$, Camila Bollafi, Débora Serretiello, Eduardo Marques, Regina França, Soraya Ocanha, Vânia Leite, Vera Abbud, Vera Figueiredo e Vitor Mendez ${ }^{8}$. Tiche Vianna ${ }^{9}$ também fazia parte de Uma Rapsódia de Personagens Extravagantes e dividiu a direção de pesquisa

\footnotetext{
${ }^{7}$ Hoje, Attilio Bellini Vaz.

${ }^{8}$ Juliano Zatti, Kleber Montanheiro, Pedro Pires, Rodrigo Matheus, Thais Ferrara e Walmir Santana também tiveram passagem pela Troupe de Atmosfera Nômade.

${ }^{9}$ Diretora e pesquisadora teatral - sócio-fundadora do Barracão Teatro, em Campinas. Especializou-se na linguagem das máscaras e na commedia dell'arte, na Itália, pela Università degli Studi di Bologna (1989/90) e pelo Firenze of Papier Machê (antigo Alice Atelier - 1988/89).
} 
de linguagens comigo, além de atuar com uma das máscaras. O foco de maior atenção do grupo eram os cômicos dell'arte, enquanto os palhaços e a direção geral encontravam-se sob meu olhar.

Quando iniciamos, eu acreditava no ideal ${ }^{10}$ da commedia dell'arte como improvisação, realizada frente ao público, com apenas um roteiro organizado antecipadamente, porém com suas construções de diálogos, gestos e deslocamentos espaciais integralmente feitas diante do público. Confiava ser possível realizar o jogo das relações das máscaras e suas características fixas, alinhavando a dramaturgia improvisada. Imaginava realizar essa empreitada com a Troupe de Atmosfera Nômade, se tivéssemos permanecido juntos, pois tínhamos uma exploração vertical com as máscaras de commedia dell'arte e dos palhaços. Durante muitos anos, investigamos a improvisação e formamos um grupo coeso improvisacional, de espetáculos pré-fixados, mas fazíamos experiências abertas e públicas eventuais, principalmente em espaços não convencionais. A pesquisa com a Troupe revelou possibilidades de caminhos de linguagem que permearam minha trajetória como um todo. Discorrerei sobre três trabalhos que hoje percebo se revela uma trilogia das máscaras com eixo no palhaço. $\mathrm{O}$ processo com maior detalhamento será $O$ Rei de Copas.

\subsection{Uma Rapsódia de Personagens Extravagantes}

Nossa primeira jornada, Uma Rapsódia de Personagens Extravagantes, encontro das máscaras de commedia dell'arte com a do palhaço, foi um sucesso inesperado. A peça propunha a discussão do próprio teatro, jogando com o lúdico e a comicidade dessas máscaras tradicionais do teatro mundial. Tomamos emprestado o princípio de Seis Personagens a Procura de Um Autor, de Luigi Pirandello, e, apoiados em canovaccio (roteiro de ações) e a partir de improvisações, criamos nosso texto, uma criação coletiva, com referências de Fellini a Shakespeare. Respeitando as tradições das linguagens abordadas, trazendo à cena a dinâmica das máscaras: ritmo, acrobacias, expressão vocal e desenhos corporais. Ao mesmo tempo, dávamos espaço para sua

\footnotetext{
10 "Os cômicos possuíam uma bagagem incalculável de situações, diálogos, gags, lengalengas, ladainhas, todas arquivadas na memória, as quais utilizavam no momento certo, com grande sentido de timing, dando a impressão de estar improvisando a cada instante". (FO, 1998, p. 19).
} 
atualização na contemporaneidade, dando abertura à reflexão sobre a fantasia, sobre o sonho, sobre o imaginário, sobre o teatro, levando em conta o prazer e a diversão.

A história era muito simples: cinco clowns desnorteados, sem rumo, invadem um velho teatro, que pertence a uma decadente companhia teatral chefiada pelo avarento Pantalone, com seus escudeiros Arlecchino, Briguella, Capitano, Doutore e Ragonda. Em busca de uma saída, a troupe de clowns e os personagens da commedia dell'arte viviam situações inadequadas, divertidas e lúdicas. A precisão do tempo das piadas cênicas, o ritmo, as dinâmicas das máscaras e o inusitado de sua utilização para a época surpreendiam, aparentavam ter vida própria.

\subsection{Mitos e Paixões}

Éramos jovens, achávamos que deveríamos realizar nosso segundo trabalho o mais rápido possível. Ainda estávamos gozando do fazer de Rapsódia quando iniciamos uma nova pesquisa, agora o encontro da tragédia grega com o palhaço. O jogo do clown era nosso eixo.

O palhaço esteve e está em meu universo de forma quase natural, integrada. E essa linguagem me instigou a novas perguntas, por exemplo, como se daria o encontro entre o palhaço e a tragédia. Cheguei à tragédia Oresteia ou A Trilogia de Orestes, de Ésquilo. Optamos por investigar quais os pontos comuns das falhas humanas do homem trágico e do homem ridículo. Trabalho riquíssimo, na investigação das intersecções de linguagens: a tragédia, o palhaço e o circo (com a utilização da perna de pau e os tecidos acrobáticos). O resultado, quando encenado, instigava o público, porém sua comunicação era fugidia, irregular. A entrada do palhaço na tragédia, suponho hoje, não recebeu a força esperada, pois nós não queríamos a paródia e nem o histriônico; desejávamos o absurdo, o patético da situação: a tragédia de Orestes, em que o pai, Agamenon, oferece a filha Ifigênia em sacrifício em troca dos ventos, para que sua frota pudesse ir ao mar resgatar Helena, em Troia. Ao regressar vitorioso da guerra, é recebido por Clitemnestra, sua mulher, que o assassina com a ajuda de seu amante, Egisto. Orestes, filho de Agamenon e Clitemnestra, vinga a morte do pai, matando a mãe, mas com remorsos, enlouquece. Optamos por colocar e retirar a máscara, o nariz vermelho, frente ao público, fazer o palhaço aparecer em momentos decisivos, às vezes no ápice dos conflitos. Eram transições, rupturas muito fortes, do estado trágico para o clownesco, o patético. Não era um exercício simples, em alguns dias tocávamos o 
patético, em outros não o atingíamos, não tínhamos regularidade, dependíamos de dias inspirados. Acredito que a envergadura do projeto era maior que nossa maturidade, mas como processo havia sido extremamente valioso, com infinitas descobertas, que não estavam necessariamente no resultado final. Sofremos muito, nos acusamos, nos reinventamos, tivemos longas e intermináveis conversas tentando entender nossos erros, nossas falhas. Aliás, Mitos e Paixões, o nome do segundo espetáculo da Troupe, era sobre falhas humanas, a tragédia humana. A pesquisa revelada entre tragédia e o palhaço é de fundamental importância no desenrolar de minha trajetória, pois a confluência dessas linguagens passou a ter força e fundamento em muitas de minhas experimentações.

A montagem de Mitos e Paixões constituiu um dos maiores aprendizados de minha vida. Mergulhamos nas tragédias gregas, lemos, estudamos pelo menos doze tragédias e as encenamos em nossos ensaios improvisacionais. Eram estudos, montagens relâmpagos, de nossas primeiras impressões sobre os textos, ou ao contrário, alguém se propunha estudar mais profundamente uma das peças, convidava parceiros dentro do grupo e direcionava o aprofundamento de investigação da tragédia que o interessava, trazendo seus pontos de vista, colocando seus desejos como ator e explorando modos de encenar. Às vezes, ocupávamos vários espaços: corredores, escadas, salas, lugares dos mais variados. Experimentávamos.

Esses estudos se deram em um prédio enorme de uma instituição ${ }^{11}$ que trabalha com a educação de surdos. Fizemos um ensaio aberto para eles, foi um momento único, pois eles capturavam a peça pela visualização e vibração produzida pelos atores no palco. Demos liberdade àqueles que quisessem tocar suas mãos ou o corpo no tablado cênico, enquanto os atores faziam a cena, pois assim sentiam melhor os acontecimentos. Apesar de uma dispersão pelos deslocamentos até o palco, ouvir os ruídos e as emissões sonoras que eles emitiam de euforia pelas sensações de recepção, para nós, foi um privilégio, uma oportunidade de retribuição.

O processo de Mitos e Paixões foi muito rico. O momento de suas apresentações foi muito irregular, vivemos um fracasso de crítica e de público. Mas ninguém negava a vitalidade da pesquisa, da proposta.

\footnotetext{
${ }^{11}$ Derdic - é uma unidade mantida da Fundação São Paulo e vinculada academicamente à PUC-SP que atua na educação de surdos e no atendimento clínico a pessoas com alterações de audição, voz e linguagem.
} 
Não é suave vivenciar um fracasso. Nós nos acusávamos na tentativa de descobrir de quem era a culpa, ao mesmo tempo olhávamos para o processo e tínhamos tantos elementos, tanto material excluído, para ir em direção a uma encenação. O projeto era ambicioso, talvez tivéssemos caminhos mais simples e essenciais. Eu certamente errei, fiz escolhas equivocadas e foi difícil atravessar essa situação. Demos tanta importância em descobrir e ir em sentido ao trágico que relegamos o aspecto mais próprio em nós, o palhaço. Hoje percebo nossa imaturidade, naquele momento, para processar uma trilogia como a de Orestes. No entanto, o cerne da pesquisa germinou, as polaridades entre a tragédia e o palhaço tornaram-se uma constante em minhas obras, a própria Troupe bebeu dessa fonte no projeto seguinte.

\subsection{O Rei de Copas - Estudo de Caso}

Quem sabe nos desafiando a fazer um terceiro movimento conseguiríamos de fato transformar toda aquela circunstância vivenciada em Mitos e Paixões? Decidimos, então, após longo processo de reflexão, recriar um filme francês, Este Mundo é dos Loucos, de Philippe Broca, considerado a comédia inicial do movimento Nouvelle Vague, sobre a I Guerra Mundial. Nossa versão se chamaria O Rei de Copas e seria assinada por Rubens Rewald.

A loucura era o nosso tema, não a loucura doentia e escura, mas sim a loucura libertária, fantasiosa e viva. A loucura que perturba a ordem estabelecida, com sua sabedoria, alienação e lucidez lúdica. Com isso, a proposta era trabalhar a loucura com humor cortante, porém sutil e delicado. Em paralelo, criávamos um fio de tensão entre as relações dos personagens e o ambiente em que viviam, enfatizando a situação limite entre a vida e a morte numa cidade condenada pela presença de uma bomba prestes a explodir.

O Rei de Copas conta a história de um soldado raso que recebe a missão suicida de salvar uma cidade da explosão de uma bomba. A população alarmada foge, esquecendo os loucos confinados no hospício. O soldado inadvertidamente liberta os loucos, que o consagram "O Rei de Copas”. Situações inadequadas, cômicas e lúdicas são criadas por sete loucos que tomam a cidade com suas fantasias e envolvem o soldado/rei, que tenta, em vão, alertá-los para o perigo de morte que a bomba representa. A trama se completa quando o soldado/rei descobre casualmente a bomba e, 
com ajuda de uma louca, por quem se apaixona, a desarma. A população retoma a cidade e o consagra herói, mas os loucos, num momento de lucidez, abandonam suas fantasias e espontaneamente voltam para o manicômio. Perturbado com o retorno súbito à realidade de herói, o soldado opta por viver junto aos loucos, confinado.

Para esse movimento, partimos para a descoberta do que denominamos louco, foco central de nossa pesquisa em $O$ Rei de Copas. A máscara, em geral, pressupõe uma transposição ou exposição. Ao cobrir o rosto, revelamos o corpo e muito do que está velado em nós. É um elemento exterior norteador de comportamentos externos e internos. Um instrumento modificador, que ao invés de esconder, como poderia ser a primeira impressão, inverte o sentido e expõe: corpo, alma e expressão do intérprete.

Nessa correlação, intuímos que a venda seria o recurso ideal, pois como máscara - faixa negra que cobre os olhos -, cega, desequilibra, retira referenciais externos e críticos, amplia ou devolve sentidos, sentimentos e sensações não muito explorados, ou simplesmente esquecidos. Dessa forma, a venda tem o potencial de fazer aflorar e colocar em foco elementos psíquicos escondidos em nós. Abre-se, assim, a possibilidade de entrarmos em contato com nossas pequenas faltas, falhas, liberdades, medos, fantasias, raivas, alegrias, uma gama de emoções inatas e emoções sociais, como culpa, vergonha, compaixão e espanto, entre outras.

Algumas ideias contidas no livro Jung e o Tarô: Uma Jornada Arquetípica, de Sallie Nichols, conduziram nossos estudos e percepções. Permitíamo-nos a liberdade de dar espaço à intuição e Jung era um bom caminho para isso, mesmo porque o desejo era trabalhar com a fantasia em nós. O louco no tarô se confunde com os palhaços, os bufões e faz contraponto com os reis. Vem de lugar algum e vai pelo caminho para lugar nenhum, mas cumpre a jornada e a repete sem fim. Suas roupas são feitas de farrapos coloridos como as de arlequim. A autora do livro aponta:

[...] A roupa colorida do Louco é o símbolo por excelência da união de muitas espécies de opostos. Suas cores variegadas e o seu desenho fortuito parecem indicar um espírito discordante: no entanto, dentro daquele caos aparente, discerne-se um modelo. Dessa maneira, o Louco se apresenta como ponte entre o mundo caótico do inconsciente e o mundo ordenado da consciência. (2007, p. 44)

A proposta era a busca do louco dentro de cada um de nós, tendo como premissas: o louco interior empurrado para vida, combinando sabedoria, sandice e desatino; o louco encerrado em polos opostos da energia, como dor e alegria; abarcando 
todas as possibilidades. Sem a energia do louco seríamos mornos, sem criatividade, previsivelmente coordenados, sem surpresas. A experimentação nos levaria, potencialmente, a estados emocionais do "louco" e era para nós a criação de uma persona que denominaríamos - o louco.

A construção das personagens se dava a partir da bagagem de cada ator, através do "jogo da venda" e de livres associações, todos os acontecimentos, fossem eles internos ou externos, poderiam ser apropriados pelo ator criador. Para que isso ocorresse de maneira autêntica, o louco era retratado nesse processo como se estivesse com os olhos vendados, o que enfatizava ainda mais a capacidade de agir antes por introversão $^{12}$ do que pela visão, utilizando a sabedoria intuitiva em lugar da lógica convencional, para dar origem a outra lógica, que perturbasse a ordem estabelecida. Eram oferecidos estímulos e induções externas que iam desde o relaxamento extremo, o silêncio absoluto, à profusão dos movimentos, fala contínua e outras variações de dinâmicas. $\mathrm{O}$ ator deveria estar atento às reações corpóreas, aos pensamentos e viceversa, onde a ação física pudesse suscitar imagens, assim como essa suscita ações. $\mathrm{O}$ foco das ações, palavras e pensamentos vinha de um estímulo interno reativo, quase como se o ator criasse uma realidade virtual baseada em si mesmo. A busca de liberdade era imensa, não recusando nada do que surgisse nos pensamentos e nas ações, liberando os desejos e permitindo as livres associações. Assim, engajávamos o universo do louco em dois mundos: o mundo real de todos os dias, onde quase todos nós vivemos a maior parte do tempo, e a terra da imaginação.

Trabalhamos muitas horas durante meses, todos os dias, sempre de olhos vendados para atingir o mais profundo de cada um. Ensaiamos em uma casa com escadaria, vários quartos e salas. Cada um dos atores ficava num quarto, sendo cuidado por um parceiro, explorando suas características. Quem estava vendado ficava separado de quem estava nas mesmas condições. Escutavam uns aos outros ao longe, percebiam os movimentos e as angústias alheias, mas não tinham acesso a elas. Às vezes, ao contrário, ao se ouvirem, criavam dispositivos para se comunicarem à revelia de quem cuidava e orientava. A rebeldia vinha à tona e jogos não pensados ou articulados previamente surgiam nos surpreendendo e enriquecendo nossas experimentações. Aos poucos, íamos "libertando" essas pessoas dos quartos, ainda vendadas, deixando que se

\footnotetext{
${ }^{12}$ Introversão (Jung): orientação predominante da energia psíquica para interior do próprio sujeito. (Dicionário da Língua Portuguesa Porto; dicionário móbile).
} 
relacionassem com o todo da casa: sua arquitetura, e com as outras personagens, aflorando os sentidos, sempre observadas e cuidadas por todos. Toda essa aventura contava com a consultoria de um psicólogo e nosso viés era a teoria junguiana. Muitos sonhos vinham à tona, histórias e fantasias.

O "louco" viria da experiência e da observação de suas reações com os olhos vendados, aos estímulos e induções apresentados, tais como: a proibição de falar ou de sair do espaço que se encontrava; ter que buscar alguém ou algo especial; guardar um segredo; às vezes, pequenas perturbações sensoriais, como, de quando em quando, tocálo e desaparecer ou jogar gotas d'águas em seu rosto e corpo, ou levá-lo para passear e deixá-lo ter a impressão de que ficou só, perdido na casa ou no quintal. Aconteceram situações inusitadas: um ator foi andar no telhado nu; uma atriz, por horas, entrava e saia da banheira cheia d'água em ato repetitivo dos mesmos gestos e da mesma frase, obcecada em colocar tudo em ordem, ao mesmo tempo que tudo ficava em desordem, pois estava encharcada. Os riscos estavam presentes, mas sempre havia outros atores, a direção, o dramaturgo por perto, às vezes, nosso consultor de psicologia, tanto para observar, como para cuidar. Muitas vezes, os estímulos vinham das imagens do filme, que nos inspiravam, ou de palavras e ações as quais os atores haviam proferido no dia anterior e provocávamos a repetição. A partir das observações sobre seus estados reativos, o ator deveria adicionar adjetivos para trabalhar como características a serem atribuídas de maneira enfática a esse "louco". Inicialmente, o intérprete-criador escolhia cinco adjetivos relacionados com sua pesquisa pessoal. Esses adjetivos indicavam atributos ao "louco" e podiam ou não estar vinculados aos personagens arquetípicos do filme de Philippe Broca. Aliás, alguns adjetivos propostos eram bastante inspirados naqueles referenciais, mas outros divergiam e tomavam outros delineamentos como construção de personagens. Os atributos pessoais descobertos na liberdade de investigação de suas emoções, sentimentos e pensamentos ocultos estavam presentes na iminência de ações compulsivas, repetitivas ou catatônicas, ou na ameaça de rupturas e violência, ou de extrema fragilidade. Por exemplo: o estado fantasioso, frágil, romântico, silencioso, quase catatônico de Vera Abbud na construção de sua colombina; a relação sistemática de Débora Serretiello na conduta de repetição obsessiva em rezar, defumar o espaço e, ao mesmo tempo, convidar ao erótico de forma seca, contraditória, frágil e perigosa de sua monja; a volúpia em ir, desmedidamente, de peito à frente, em plena alegria, inocência e cheia de ameaça de Juliano Zatti e seu arquiteto; e a doçura 
explosiva de Regina França em sua prostituta pudica. Todos tinham um lado luminoso e outro em sombra, que ofereciam um estado de alerta constante.

A "venda" foi retirada dos olhos, paulatinamente, para que o ator-criador pudesse expressar através dos olhos a vibração e a pulsação interior do louco e fosse investigando o acesso àquela força interna, pela apreensão da prática vivenciada pelo saber empírico do processo de pesquisa. Essa persona possuía vivência ativa e liberta, tinha vida própria, com dor, humor, divertimento e inocência de sua condição de angústia. Nascia da correlação e fusão das pesquisas anteriores com a commedia dell'arte e o palhaço em Uma Rapsódia de Personagens Extravagantes, e do palhaço e a tragédia em Mitos e Paixões. A exploração de todas essas linguagens anteriores, articuladas pelo jogo teatral, estruturou como verdadeiros veículos a construção desse novo personagem e o próprio espetáculo, O Rei de Copas.

Durante todo o processo tivemos vários contatos e palestras com psicólogos e psiquiatras, assim como fizemos uma visita a uma instituição psiquiátrica, uma clínica de repouso, ${ }^{13}$ perto de São Paulo, que foi extremamente reveladora. Era dia de visita, chegamos cedo e nos deparamos com um espaço aberto, um jardim, com os pacientes de variados graus de loucura. Podíamos conversar com eles livremente desde que houvesse o aceite de cada um, sem nenhum tipo de obrigação ou pressão. Nós, da Troupe, nos separamos e fomos viver esse dia junto aos internos e seus visitantes. Vimos e ouvimos pessoas muito interessantes e intrigantes, às vezes figuras quase caricaturais desse universo e outras vezes nos perguntávamos o porquê daquela pessoa estar ali. Particularmente, em alguns momentos, como havia internos e visitantes, houve instantes em que essa borda entre loucura e sanidade se desfez, e já não sabíamos quem era quem. Ao voltar para São Paulo e conversar sobre a visita, tínhamos relatos de histórias, comportamentos e situações desconcertantes que envolviam a todos, incluindo o fato de um de nós ser confundido com um paciente. Em seu livro O que é Loucura, João Frayse Pereira, articulando sobre a História da Loucura, de Michel Foucault, nos aponta:

[...] pode-se dizer que até o final do século XVI não havia fundamento para a certeza de não estar sonhando, de não ser louco. Sabedoria e loucura estavam muito próximas. E a grande via de expressão dessa proximidade era a linguagem das artes: a pintura, a literatura, sobretudo o teatro que, no final do século, vai desenvolver a sua verdade, isto, é, a de ser ilusão: "algo que a loucura é, em sentido estrito". (1984, p. 59)

\footnotetext{
${ }^{13}$ Clínica de Repouso Santa Fé (Comunidade Terapêutica Psiquiátrica) - Itapira, 17 de junho de 1994.
} 


\subsubsection{A dramaturgia em $O$ Rei de Copas}

A construção do texto se deu de forma gradual, com Rubens Rewald como dramaturgo, arquitetando a dramaturgia ao longo do processo em diálogo constante com a direção e os atores-criadores, em nossa primeira parceria. Rubens, em Caos/Dramaturgia, ao desenvolver a ideia do "autor-espectador", afirma:

O dramaturgo, mais do que exercer a função de autor da obra, constitui-se como o intérprete textual das experiências vividas durante o processo. Os ruídos ou flutuações podem surgir a qualquer momento e cabe ao dramaturgo assimilá-los ou não no corpo dramático da peça. Para tanto, é fundamental um exercício de escuta incessante praticado pelo dramaturgo [...]. (2005, p. 23)

O ator participava ativamente de todo o processo de criação, o que não era tão comum naquela época. A aceitação da reescrita dos diálogos criados em sala de ensaio tinha acomodações processuais dinâmicas e polêmicas. A capacidade de ser flexível exigida no processo colaborativo ${ }^{14}$ é intensa, pois requer muita escuta de todos os lados envolvidos. Embates aconteceram. Escrever ou reescrever o que foi dito, no fogo do jogo e das improvisações pelas personagens criadas pelos atores, com suas lógicas próprias, é tarefa delicada. Assim como é missão transpor e receber um novo texto e conseguir assimilá-lo, tanto para atores como para a direção. Estabelecer um diálogo honesto com todos os parceiros envolvidos no processo criativo é fundamental. Certamente este não é um trabalho estático, é necessária muita generosidade no caminho e abertura para um verdadeiro trilhar processual. Ao final, a estrutura do roteiro lembrava em muito o filme, que nos inspirava, mas as variantes tanto de ensaio como de escrita foram transformando o caminho do texto e da montagem.

No filme, os loucos são sábios, doces e divertidos. Em nossa peça, essas características estão presentes, porém, os loucos manifestavam uma dose de perigo, o que não aparece no roteiro que nos inspirou.

\footnotetext{
${ }^{14} \mathrm{O}$ processo colaborativo é dialógico por definição. Isso significa que a confrontação e o surgimento de novas ideias, sugestões e críticas não só fazem parte de seu modus operandi, como também são os motores de seu desenvolvimento. Isso faz do processo colaborativo uma relação criativa baseada em múltiplas interferências (ABREU, 2004).
} 
Este Mundo é dos Loucos ou Le Roi de Coeur foi realizado em 1966, momento de eclosão do movimento hippie, em que o antimilitarismo e o não à guerra eram tratados de forma emblemática, alegórica, utópica, o que revelava uma crença esperançosa nos seres humanos, na paz e no amor. Estávamos em 1995, e apesar da queda do Muro de Berlim, do fim da Guerra Fria e de algum sonho de paz serem o contexto, tivemos ainda a Guerra da Bósnia, a Guerra do Golfo (a primeira), ao vivo e em cores, televisionada em tempo real; além disso, as questões com a AIDS ainda eram muito difíceis e não havia no ar um movimento de esperança e inocência como nos anos 1960. Apesar de nossa utopia, em $O$ Rei de Copas havia ameaça e dúvida em alguns momentos em que nossos loucos, por sua imprevisibilidade característica, colocavam em risco a integridade daquele que os vinha salvar, o soldado/rei. Um bom exemplo disso é o cozinheiro real, criado por André Pink, que levava nas mãos um grande facão, que tinha tendências canibais e, por motivo torpe, leva a julgamento "O Rei de Copas", Plantik, soldado perplexo e de boas intenções, tocador de clarinete, construído por Eduardo Marques. O dramaturgo queria acentuar a instabilidade dos loucos fortalecendo o perigo, ainda que de forma satírica. Criou o julgamento do soldado/rei, em que sua defensora era uma atriz decadente, que fazia "o ponto" e assumia a culpa dizendo ser Madame X, numa citação da famosa assassina do cinema. ${ }^{15}$

Aliás, a linguagem cinematográfica, além de inspirar a peça, tem no cineasta Rubens Rewald, ${ }^{16}$ ali como dramaturgo, presença constante na concepção de direção, de espacialidade e na trilha sonora criada exclusivamente para a montagem, induzindo emoções. O Rei de Copas possui forte tonalidade do melodrama com acento cômico. A trilha sonora original, composta por Pedro Paulo Bogossian, foi composta a partir de instrumentos de corda (violino, violoncelo e guitarra), para climatizar a guerra, enquanto os personagens do manicômio foram representados por instrumentos de sopro e sintetizador. A música tinha presença marcante em toda a peça. Tanto assim que em muitos ensaios, próximo à estreia ou mesmo como exercício de aquecimento para o espetáculo, a trilha era usada como trajetória de toda a peça. O exercício se caracterizava pela retirada da palavra, e as personagens deveriam fazer todo o percurso guiadas por seus impulsos internos, deixando a pulsação do corpo dirigir o movimento, em deslocamento aos momentos de relações com as outras personagens objetos e suas marcas, comunicando-se pelos gestos e pelo olhar. Todos começavam juntos o

\footnotetext{
${ }^{15}$ Madame X, clássico melodramático que tem Lana Turner como protagonista.

${ }^{16}$ Corpo, (2007); SuperNada, (2012).
} 
exercício, mas o tempo de cada um variava para a realização de cada etapa. Nós trabalhamos o corpo com a técnica Klauss Vianna ${ }^{17}$, oferecida por nossa preparadora corporal Neide Neves ${ }^{18}$, que estruturou os corpos para a vivência dos estados emocionais da loucura desde o princípio do processo. Os intérpretes se moviam de forma consciente pelo espaço, cada um com suas características e dinâmicas corporais, atribuídas às suas personagens.

Para a criação do espaço cênico tínhamos o porão do Centro Cultural São Paulo, até então pouco usado para encenações: um lugar largado, descuidado, sujo, com estruturas de concreto entulhadas. Entramos com intuito de ocupação, de tirar o melhor proveito da amplitude daquele espaço de concreto, perfeito para a sensação de uma cidade abandonada. Queríamos dar ao ambiente o aconchego lúdico do circo, estabelecendo a dualidade entre a tensão e a diversão. O espaço amplo, longitudinal, reproduzia a situação desoladora da cidade, com esculturas de ferro: uma gaiola enorme $^{19}$, sete espelhos, tambores de óleo; sofás, sacos de estopa, roupas espalhadas, bicicletas, elementos do cotidiano se misturando aos elementos da guerra. A serragem recobria o chão, como em um picadeiro e um arame usado pela equilibrista/colombina nos remetia à fantasia. $\mathrm{O}$ cenário, criado por Atílio Belline Vaz, em cena com seu doce e hesitante general, era também responsável por fortalecer através de cores fortes a ludicidade da montagem por meio dos figurinos. Juliano Zatti desenhou a luz do espetáculo, além de estar em cena. Os integrantes da Troupe eram muito ativos na elaboração e execução das etapas de criação e de produção - uma experiência coletiva. Nesse intuito, construímos um teatro, toda a estrutura de logística de luz, de som, todo cabeamento das fontes de energia, no porão do Centro Cultural, com a ajuda de alguns parceiros. Nosso lema era colocar a mão na massa em todas as instâncias da feitura do processo, como aprendizado e como solução financeira.

O Rei de Copas, inspirado na utopia da paz, do amor e do não à guerra, formulava a discussão central proposta no filme, estrelado por Alan Bates ${ }^{20}$, ao questionar: Em quem está a loucura? Nos asilos dos alienados? Nas guerras? Nas

\footnotetext{
${ }^{17}$ Klauss Vianna era bailarino, coreógrafo, escreveu o livro A Dança e criou a Técnica Klaus Vianna, sistematizada por seu filho Rainer Vianna e Neide Neves.

${ }^{18}$ Neide Neves é pesquisadora, preparadora e dramaturga corporal. Leciona no Curso de Comunicações das Artes do Corpo, na PUC-SP, onde coordena o Curso de Especializacão na Técnica Klauss Vianna.

${ }^{19}$ No filme, o soldado/rei é o responsável pela comunicação e carrega dois pombos-correios em pequena gaiola. Em nossa montagem, era o lugar onde ficavam os loucos no início da peça, o asilo dos insanos - a gaiola.

${ }^{20}$ Ator Inglês de filmes como Zorba, o Grego (1964), O Homem de Kiev (1968), A Rosa (1979), entre outros. Em Este Mundo é dos Loucos fazia o soldado, identificado pelos loucos, como o rei de copas.
} 
instituições da ordem social? Assim, Rubens, ao brincar com uma das senhas, as quais o soldado recebeu para a descoberta e desarme da bomba, traz uma metáfora muito bemvinda, tornar visível o invisível. ${ }^{21}$ Essa frase, para ele, teve indicações sobre o trabalho da venda nos olhos na construção dos loucos em nossa pesquisa da loucura, pois, teoricamente, os loucos seriam aqueles que não conseguem ver, mas na verdade veem mais do que todo mundo. A loucura dá a eles permissão para ver; porque não estão cegos pela cultura, pelo dia a dia, pela economia, pelos problemas, pelo consumo; já ultrapassaram todas as barreiras; lembram os bufões que têm liberdade de enxergar e dizer a verdade. Na peça, o soldado é coroado com uma coroa feita de restos de ferro e fios e, a todo momento, sai em busca da bomba, desesperado com a finitude do tempo, sem saber que carrega em sua cabeça o objeto de sua procura, um verdadeiro homem bomba. "Por ter muito para ver, nossos olhos, com frequência, não conseguem ver coisa alguma", nos diz Jean Claude Carrière (2006, p. 24), sabiamente, ao abrir nossos olhos e revelar a metáfora do mestre do teatro:

Peter Brook costuma dizer que dirigir uma peça é tornar visível o invisível. A imagem do encontro decisivo com a plateia existe desde que o trabalho começa, na própria escolha da peça. Mas existe como uma forma imprecisa, imersa numa névoa. Todo o trabalho subsequente precisa se concentrar na elucidação dessa forma, tornando-a vívida e palpável. Ao longo do percurso, inevitavelmente, a névoa irá se dissipando e revelando contornos precisos [...]. (CARRIÈRE, 2006, p. 32)

Fizemos uma peça romântica, com humor e emocionalmente tocante - fomos felizes. Dessa vez, tivemos o reconhecimento do público e da crítica, tendo nossa pesquisa de linguagem sido reconhecida com o prêmio da Associação Paulista dos Críticos de Arte (APCA). Entretanto, o grupo se desfez; apesar de toda admiração e afeto, nos separamos. A pesquisa se mostrou vital em todos os sentidos: os corpos foram afetados em sua energia, no seu modo de andar, de se relacionar, de falar e de olhar, sustentados pelo trabalho de consciência corporal e pelo universo solitário da loucura. Tanto assim que na temporada de 1995, o público se emocionava, às vezes de forma desbragada. Quando da oportunidade de realizar, no ano 2000, uma retrospectiva de meu trabalho, ${ }^{22}$ nós revisitamos $O$ Rei de Copas, mas não a pesquisa de imersão na persona do louco, o que fez com que sua essência não ficasse tão aflorada.

\footnotetext{
${ }^{21}$ Pensamento de Jean Claude Carrière, contido no livro A Linguagem secreta do cinema (2006, p. 32).

${ }^{22}$ Perspectiva, Cristiane Paoli Quito: Um Olhar em Movimento. Realizei junto com meus parceiros de cena uma retrospectiva de dez anos de trabalho, a convite de Sebastião Milaré, crítico de teatro, escritor e
} 


\section{Capítulo III - Ponto de Mutação: O Encontro com a Dança}

\subsection{Pina - Peletier - Sabático}

O desejo de entrar no mundo da dança nunca foi algo planejado. Nasceu de forma contundente depois que assisti ao espetáculo de Pina Bausch, Cravos, no Festival de Edimburgo de 1995. Talvez toda a experiência acumulada até chegar ali tenha permitido que eu recebesse de fato o trabalho de Pina Bausch, sua delicadeza e força na construção da dança permeada pelo teatro. Havia recém-concluído no Sesc Consolação um curso intensivo de uma semana, oito horas por dia, com Pol Peletier, atriz e pedagoga canadense. Seu curso continha elementos de relaxamento, como massagens, e também trazia a meditação ativa de $\mathrm{Osho}^{23}$, na qual o primeiro movimento é respirar sempre pelo nariz, de maneira caótica, quebrando qualquer ritmo; depois, em um segundo movimento, trabalhar socando almofadas e trazendo uma língua ininteligível, gibberish, toda raiva, descontentamento, frustrações, xingamentos, no intento de colocar para fora o que está engasgado, quase como a realização de uma catarse. No terceiro movimento, com os braços levantados, as mãos abertas e os pés paralelos, saltar seguidamente emitindo de forma intensa o mantra $\mathrm{HOO}, \mathrm{HOO}(\mathrm{Ru}, \mathrm{Ru})$. Quando os pés tocam o chão, sente-se o martelar do mantra no assoalho pélvico. Essas três etapas duram dez minutos cada. Depois, num quarto movimento de quinze minutos, deve-se parar, na posição que estiver, de forma estática. Mesmo que se tenha parado com braços e mãos erguidas, ficar sem se mover. Aqui o importante é ser uma testemunha, um observador do fluxo de energia do corpo e das questões da mente que irão gritar,

curador de teatro do Centro Cultural São Paulo naquele momento. A mostra apresentou oito de meus espetáculos e aconteceu no Porão do CCSP, de dezembro de 2000 a março de 2001.

${ }^{23}$ Quando vivo, era chamado Bagwan Shree Rajneesh, depois de sua morte Osho. Indiano, foi professor de filosofia na Universidade de Jabalpur, Índia, nos anos 1950. Criador de um movimento espiritual centrado nas meditações ativas, criadas por ele, fundamentadas nas tradições zen-budistas, tântricas e sufista nos anos 1960 . 
certamente, em absoluto silêncio. Por fim, vem o quinto e último movimento, em que se celebra a vida através da dança.

Quando fiz o curso de Pol Peletier notei que havia trabalhado essa meditação nos anos 1980 e fiquei encantada ao ver alguém utilizando essa mesma técnica para o teatro. A energia se modifica, se transmuta. Muitas pessoas, atrizes e atores, deixaram o curso no primeiro dia, pois as meditações causavam secreções, ficávamos expostos à nossa fragilidade e rigidez. O trabalho pressupunha uma disponibilidade de entrega, que talvez nem todos estivessem preparados ou no momento de viver um processo de ruptura de padrões que esse tipo de meditação provoca, mas quem ficou até o fim, se deliciou com os exercícios diferentes e reveladores. Ela trabalhava com os chacras e as glândulas, e as relacionava com as articulações. Ao fazer essas relações, propunha modelos de atuações teatrais. Trabalhava fundamentalmente com o abrir de nossos sentidos e com a percepção aguçada de nós mesmos e dos outros. Dizia que estar em cena era estar em um supraestado e que deveríamos saber ligar e desligar essa energia, para entrar e sair de cena. Ao terminar o curso, preferi me manter ligada. A despeito de ser um exercício cênico, tentei permanecer nesse supraestado, experimentar em outras situações. Assim, no dia seguinte ao termino da oficina, trabalhei com meu grupo nesse estado e foi muito positivo. Porém, depois de três dias, meu corpo sofreu um revertério, tive febre, vômitos, suores, aprendi o porquê e a importância de desligar.

Peletier nos convidou para um curso de longa duração em Montreal, no Canadá. Muitos de nós resolvemos ir, inclusive eu. Porém, dois ou três dias antes da partida, ao chegar em casa à noite, ouvi na secretária eletrônica um recado em que ela dizia que o curso estava cancelado. Decidi ir mesmo assim. Tinha a passagem, o dinheiro do curso, iria aproveitar e passar ao menos três meses fora. Mas fazendo o quê? Assistindo aos festivais de verão no Canadá e na Europa. Cheguei a procurar Peletier ao chegar a Montreal, mas me disseram que ela havia ido passar um tempo com os índios e seus xamãs.

Resolvi aproveitar e conhecer a cidade. Fui a um desses guichês de turismo, perguntei o que havia de bom para se fazer naquele momento, me disseram que estava acontecendo o Festival Internacional de Jazz de Montreal, um grande evento de música e artes, onde as apresentações aconteciam na rua, em vários quarteirões, dia e noite, e também nos palcos dentro dos teatros.

Naquele ano de 1995, além de B.B. King, Buddy Guy e outros grandes músicos, aos quais assisti, havia uma homenagem ao Cirque du Soleil, que tinha, na ocasião, por 
volta de dez anos de existência, era proeminente e um orgulho nacional. Tanto assim que o Festival tomou para si o tema circense como inspiração. Perguntei à guia turística se havia algo para ver de teatro, ela me disse: "Há o ensaio do Cirque du Soleil acontecendo na rua e nos prédios, mas é ensaio". Corri lá para ver. Não tinha toda a projeção internacional que tem hoje, mas estava prestes a viver esse momento de transformação. Era tudo grandioso, as paredes dos prédios estavam tomadas de assalto por bicicletas, escaladores, palhaços; um show feito para o festival com um coral formado por numerosas pessoas, africanos em sua maioria, cantando para as virtuoses de palhaços, funâmbulos, exímios malabaristas em ensaio, errando e acertando, repetindo, sem aparatos de roupas e luzes, tudo muito interessante, para mim, principalmente porque eu também trabalhava com circo, por meio de uma parceria forte com Rodrigo Matheus. ${ }^{24}$ Vi e ouvi muita coisa. Estava só, numa atitude de observação das artes e da cultura de uma cidade em festa de verão. Passei cerca de vinte dias conhecendo, vibrando, me disponibilizando para os acontecimentos.

Na cidade de Québec também começava seu festival de rua. Seguindo minha aventura, me dirigi para lá, afinal viajei para fazer um curso que não aconteceu, e Pol Peletier, sem saber, estava me dando outro curso, um curso de vida. Continuava sozinha e bastante introspectiva; falava apenas o essencial com pessoas que indicavam direções ou com vendedores dos lugares. Estava me sentindo bem assim. Minha pousada ficava à beira do rio São Lourenço, que margeia a cidade. Sentava na praça principal com o folder do festival de rua nas mãos, buscava o que me interessava, me deleitando com a paisagem de cidade histórica, tão diferente das nossas no Brasil. O inverno no Canadá é intenso e por isso o verão torna-se uma benção.

Estive também em Toronto, cidade de grandes dimensões, onde o deslocamento era diferente de Québec: exigia transporte e um cuidado maior na busca do que ver.

A experiência de estar só durante um mês, assistindo a tantas manifestações artísticas, sem ter com quem compartilhar, aflorou o meu eu-observador. A não obrigação do fazer, o ócio, me trouxeram a sensação de alimento.

Do Canadá parti para Londres, cidade em que havia morado entre 1988 e 1989. Dessa vez, me hospedei na casa de uma prima, mais jovem do que eu, artista também, hoje cineasta, Tuca Paoli. O lugar estava sempre em festa: muita gente o tempo todo,

\footnotetext{
${ }^{24}$ Rodrigo Matheus é circense, uns dos introdutores do Novo Circo no Brasil. Criamos juntos dois espetáculos: Prometeu Acorrentado, de Ésquilo, em 1993 e Moby Dick, de Herman Melville, em 2004 Duas adaptações para teatro, na qual fazíamos uma releitura da utilização do trapézio.
} 
jovens procurando seus caminhos. Ali fiz amigos, ouvi histórias, compartilhei sonhos, ideias e invenções.

Nessa época, revi Philippe Gaulier, que acabava de se mudar para Londres e me convidou para assistir alguns dias do seu curso de clown. Depois das aulas, íamos ao $p u b$ tomar cerveja e conversar. Ver seu trabalho, sem ter a responsabilidade de estar em cena, foi um aprendizado diferente; trocar ideias e ouvi-lo falar era bastante enriquecedor.

Ir ao Royal Festival Hall, ao lado do Rio Tamisa, assistir a peças, a eventos no roof, a céu aberto, em horário de verão, era uma oportunidade única de ver espetáculos diferenciados, que me faziam refletir sobre o fazer teatral na rua e seu aproveitamento como lugar de exploração de arquitetura.

O mesmo aconteceu em Aurillac, cidade feudal francesa. De Londres fui a Paris encontrar dois integrantes da Troupe de Atmosfera Nômade, Camila Bolaffi ${ }^{25}$ e Pedro Pires, ${ }^{26}$ ambos alunos de Jaques Lecoq e que estavam de partida para se apresentarem no Festival de Rua de Aurillac ${ }^{27}$. Acompanhei-os numa viagem de carro em direção ao centro leste da França. Novamente, assisti a incontáveis espetáculos de rua. Bastava sentar em uma esquina e a maioria dos espetáculos vinha até você. Havia também eventos espetaculares, como os da Companhia Royal de Luxe ${ }^{28}$, que eu havia visto em São Paulo, em 1992. No festival de Aurillac, a companhia mostrava Le Peplum, sobre os dois mil anos da história do Egito; tudo em grandes proporções cenográficas e com muito humor. Deixei-me levar pelos trabalhos e pelas ruas do festival, observava os detalhes, as feituras, as finalizações e as preparações das apresentações. Toda essa experiência se dava no centro histórico de Aurillac, com aspectos feudais, ruas estreitas, edificações de pedra, musgo, um pequeno rio e sua ponte. Uma sensação de volta ao passado, tomado por uma festa do teatro de rua. Começava às dez da manhã e seguia madrugada adentro, numa espécie de carnaval de intensidades.

$\mathrm{Na}$ minha percepção, as atrações mais provocantes nem sempre eram aquelas mais espetaculares, mas sim as que deveriam ser descobertas em seus detalhes diferenciados. Em geral, eu gostava de apreciar as performances sem palavras, em silêncio, talvez pelo contraste com a tônica dos espetáculos de rua, onde tudo parece

\footnotetext{
${ }^{25}$ Cuca Bolaffi é atriz e professora, leciona na Escola Livre de teatro de Santo André.

${ }^{26}$ Pedro Pires é diretor de teatro e dirige a Companhia do Feijão em São Paulo

${ }^{27} 10^{\mathrm{a}}$ edição do Festival Internacional de Aurillac - de 23 a 26 de agosto de 1995. Criado em 1986, é o primeiro festival exclusivamente de rua europeu.

${ }^{28}$ Companhia Royal de Luxe, criada em 1979 por Jean-Luc Courcoult. Esteve no Brasil em uma turnê pela América do Sul, em 1992 num navio Cargo92.
} 
mais externo, há exuberância de cores e sons, até para que sejam vistos, e há força na voz quase gritada.

Depois de algum tempo nessa viagem aos teatros de rua, comecei a procurar o não óbvio nessa linguagem. Assim, vi outros espetáculos com potenciais delicados e simples. Havia um grupo de seis personagens que se caracterizavam como $O s$ Burgueses de Calais, escultura de bronze de Auguste Rodin sobre a Guerra dos Cem Anos. Infelizes, sofridas, as roupas em trapos, descalços, uma corda no pescoço em cada um deles, nas mãos as chaves da cidade e do castelo. Poderia ser mais uma escultura viva, mas iam além disso, pois trabalhavam a composição entre eles e as direções no espaço, provocando tridimensionalidade. As localizações escolhidas para se colocarem em posições inusitadas provocavam releituras de um mesmo objeto. Durante os dias de festival me divertia procurando onde estariam aquelas figuras, e as encontrava dentro do rio ou em cima de uma edificação de pedra esverdeada pelo tempo, ou na entrada da igreja, fazendo desviar os visitantes. Surgiam em longas pausas com mudanças sutis por toda cidade, contavam a dramaticidade de um evento importante para a história da França e da própria obra ${ }^{29}$, porém, as pessoas passavam por eles e nem os percebiam. Aliás, comecei a prestar atenção aos transeuntes e seus comportamentos.

Em uma das intervenções de rua, elfos em pernas de pau misturavam-se às heras, trepadeiras, que tomavam as paredes das casas de pedra de dois, três andares. Ali se amalgamavam e desapareciam, ficavam escondidos por bom tempo. Aos poucos, sem alarde, despregavam-se das paredes. $\mathrm{O}$ que acontecia às pessoas que por lá passavam era muito melhor que muitas performances. O susto, o assombro, a raiva, a diversão, quando se davam conta do que acontecia, definiam a alteração de foco, sem que muito fosse feito. Os artistas não colocavam intenção alguma, apenas saiam das paredes e das heras, pertenciam àquela natureza; depois, apenas retornavam às paredes, à latência e às trepadeiras. Naquelas ruelas, passei horas observando o tempo das entradas desses performers. Nem todas as entradas eram iguais, pois ritmo, tempo e volume variava. Às vezes, aparecia um só, em outras, todos, o que modificava as reações do público e de minhas percepções de observadora. Essa apreensão trouxe questões: quem performa?

\footnotetext{
${ }^{29}$ A escultura original fica diante da prefeitura de Calais e há onze edições dessa obra pelo mundo feitas pelo atelier de Rodin.
} 
Onde está o foco? Qual o começo e o fim? Mais tarde essas questões reverberaram em meus projetos, principalmente em espaços abertos e não convencionais. ${ }^{30}$

Ao final do Festival de Aurillac, tendo assistido a numerosos espetáculos de artes cênicas de rua, decidi voltar para Paris. Estava satisfeita, preenchida, mas ainda tinha um último compromisso de aprendizado informal. Havia comprado por telefone um ingresso para assistir a Cravos $^{31}$, de Pina Baush, no Festival de Edimburgo. Uma oportunidade de voltar à Escócia e ao festival em que havia estado em 1989 como participante do Fringe Festival e também como espectadora desse que é considerado o maior festival de artes do mundo.

Depois de vivenciar dos espetáculos de rua em Aurillac, em que se está sujeito às intempéries, a todo tipo de interferência, assim como às dificuldades de escolhas do que ver, entrei saudosamente em uma sala de teatro, das mais tradicionais da Escócia. ${ }^{32}$ Estava na quinta ou quarta fileira próxima ao palco e com visibilidade do todo. O palco, coberto de milhares de cravos em pé; os figurinos de delicados panos, vestidos de seda; uma bailarina de calcinha e salto alto segura o acordeom, sua veste; um bailarino recita em libras, suas mãos em dança, ao mesmo tempo em que sussurra a letra de The Man I Love, de Ira Gershwin, enquanto ouve-se a voz de Sophie Tucker ${ }^{33}$ cantando a canção. Movimentos soltos, leves, densos, cadeiras e mais cadeiras, brincadeiras, risos, choros, palavras, repetições, cotidiano, histórias pessoais, pequenas canções, relações e sentimentos, braços, muitos movimentos de braços, correrias, pausas, cães - sim!, cães, quatro, enormes. Repressão, homens de terno preto perguntam incessantemente: "Seus passaportes?" Sempre uma pergunta dolorida para quem está e viveu como estrangeira em tantos lugares, mesmo que esteja tudo certo. Ver os bailarinos de muito perto, sentir a exuberância, a paixão de suas entregas e a força da dança e do teatro ao mesmo tempo. O primoroso cuidado e a delicadeza da montagem faziam tudo vibrar numa sinestesia antológica.

\footnotetext{
${ }^{30}$ Águas de Março para Lina Bo Bardi, de 1999, trabalho de ocupação da área interna de convivência do Sesc Pompeia realizado pela Cia. Nova Dança 4 e convidados do Estúdio Nova Dança. Esse projeto se transformou em uma série que denominamos Passeios.

- Poetas ao Pé d'Ouvido, invenção de 1998/99, que se fazia como apresentações minimalistas em rua. Um performer para um espectador, buscando o máximo de delicadeza e aceite do público (se esse não se abrir, a performance não se efetiva - sem imposições). Realizados com poesias, dança, canto e contação de histórias.

${ }^{31}$ Tanztheater Wuppertal, a primeira versão foi apresentada em dezembro de 1982 e versão final estreou em maio de 1983.

${ }^{32}$ Edinburgh Playhouse Theatre, em 2 de setembro de 1995.

${ }^{33}$ Sophie Tucker 1887-1966, cantora, comediante, atriz e personalidade do rádio americano, ucraniana de nascimento.
} 
Ao término do espetáculo, meus pensamentos diziam que depois de vinte anos de teatro talvez fosse tarde para me aproximar da dança. Ainda assim, desejei a dança. Ao sair do teatro, vivi uma verdadeira epifania com Cravos, de Pina Bausch, com direito a fogos de artifício e música clássica tomando os meus ouvidos e a cidade. Era o último dia do festival e, como tradição, o Castelo de Edimburgo finaliza a festa com um concerto de orquestra e uma queima de fogos. Estava impactada. Já havia visto outros trabalhos de Pina Bausch no Brasil, em São Paulo no Teatro Municipal, mas algo me tocou de forma tão diversa daquela vez. Ao voltar para o Brasil, em menos de um mês, conheci a bailarina Tica Lemos e o Estúdio Nova Dança. Uma reviravolta se deu. Fui viver, aprender e pesquisar a dança. Em troca, levei o teatro para dentro do Estúdio Nova Dança.

\subsection{Estúdio Nova Dança, Tica Lemos e o Pensamento Corporal}

Quando conheci Tica Lemos, em 1995, ela havia recém-inaugurado o Estúdio Nova Dança com outras três sócias, Adriana Grechi, Lu Favoreto e Thelma Bonavita ${ }^{34}$. O Estúdio viria a ser uma referência de dança e de elaboração da dança teatro no cenário paulista. Tica havia se formado ${ }^{35}$ na School for New Dance Development (SNDO), em Amsterdã, na Holanda, tendo como foco principal, a dança de contato improvisação que ela viria introduzir no Brasil.

As quatro empreendedoras eram figuras com larga experiência. Mesmo jovens, traziam técnicas e pensamento de dança contemporânea e estavam naquele momento investindo no diálogo entre as correntes contemporâneas de dança. Ao assistir aos ensaios dos espetáculos ${ }^{36}$, produzidos por elas, vi muita proximidade com o que eu desejava fazer. Era tudo muito vivo, havia jogo naquelas danças, precisão, virtuose, estratégia, mas a coreografia não era completamente imposta pelas coreógrafas, ela se constituía junto aos bailarinos. Julguei que esse processo se assemelhava aos procedimentos engendrados em minhas pesquisas e espetáculos em teatro. Construir

\footnotetext{
${ }^{34}$ As quarto sócias-fundadoras do Estúdio Nova Dança são diretoras, coreógrafas, bailarinas e professoras de dança.

${ }^{35}$ Formou-se em 1987.

${ }^{36}$ Quasi Fuga, dueto dirigido por Thelma Bonavita, tendo Cristian Duarte como intérprete-criador e parceiro de cena.

Lembranças na Queda, com direção de Adriana Grechi, em que Lu Favoreto, Geogia Lengos, Gil Grossi e Tica Lemos eram intérpretes-criadores. Os dois espetáculos foram criados em 1995.
} 
junto aos meus parceiros de cena, um imaginário que através dos corpos deslocamentos, relações, tempo, ritmo e fluxo - comunica. Porém, meu universo até então era permeado pelos textos, pelo corpo e pela emissão das palavras. O convívio no Estúdio Nova Dança era intenso, cheio de trocas, fossem nas salas de aulas, no saguão, terraço - nosso roof, onde se localizava a pequena cantina, nosso ponto de encontro, de outras danças e muitas festas, com a vista de São Paulo ao redor.

A dança improvisacional era uma realidade para Tica Lemos, que realizava pequenos solos de improviso e trabalhava com a dança de contato improvisação. Nosso encontro revelou uma oportunidade de troca de interesses nas linguagens que cada uma trazia, a dança e o teatro, somados à improvisação. O teatro para ela não era novidade, pois trabalhara como atriz em Brasília, sua cidade natal, e em São Paulo realizava preparações corporais para espetáculos e grupos de teatro. Meu momento era de recomeço. Apesar de estar no teatro há dezoito anos, sentia necessidade de viver e conhecer a dança, de travar novos conhecimentos.

O pensamento de criação e pedagogia que se desenvolvia de maneira informal no Estúdio Nova Dança era propulsor de ideias e terreno fértil às experimentações. As quatro sócias criaram um espaço dinâmico onde a proposta "nova dança" 37 podia fluir e ampliar as discussões sobre o universo do movimento. O estúdio praticava e pesquisava a dança contemporânea, o contato improvisação, a nova dança e a criação de espetáculos. A educação somática ${ }^{38}$ veio se estabelecendo como base do pensamento nas salas de aulas e nas companhias.

Ao frequentar, como aluna, as aulas oferecidas por Tica, percebi uma dilatação diferenciada do tempo e do ritmo cotidianos. Deitar no chão, relaxar profundamente, ganhar espaço interno para alinhar corpo e mente, na observação do todo ${ }^{39}$, tudo isso propiciava um estado de consciência corporal, em um processo próximo à meditação. Observar o peso do corpo no chão, a gravidade agindo na massa corpórea, na experiência imaginativa de ir ao centro da terra, com tempo e respiração, me tornava receptiva à experimentação e entrega à dança.

Estudávamos o esqueleto humano - observando e tocando parte de um esqueleto

\footnotetext{
${ }^{37}$ No contexto da New Dance, ou Nova Dança, não há mais o biotipo ideal para quem dança: todo corpo tem potencial de dança em si, independentemente da idade, do tamanho, do peso e das limitações físicas.

38 A educação somática surge no século XX, a partir de estudos empíricos de pesquisadores, em seus próprios corpos, como a Técnica Alexander, a Eutonia, o Rolfing, o Método Feldenkrais, a Técnica Klaus Vianna e o BMC- Body-Mind Centering.

39 “[...] a mente é tão estritamente moldada pelo corpo e destinada a servi-lo que somente uma mente poderia surgir desse corpo. Não há mente que não tenha um corpo" (DAMÁSIO, 2000, p. 187).
} 
de resina ou por meio de imagens ósseas de livro de anatomia - para que posteriormente fizéssemos massagens - toques nos nossos próprios ossos ou nos ossos de nossos parceiros de aulas. Deveríamos relaxar e ao mesmo tempo ficar atentos aos toques no osso que recebíamos, deixando a imaginação viva identificar relevos, texturas, e a sensação "do acordar o osso que é tocado". Eram oferecidas palavras e sugestões para as percepções de movimento, peso, resistência, formato do osso, assim como as possibilidades de direções que o osso tomaria internamente, no corpo, e externamente, no espaço. A porosidade do osso, o deslizar dos ossos nos músculos, a sensação do sangue dentro do osso e em seu entorno. Essas, além de outras percepções e sensações, deveriam estar conectadas com nossas imagens mentais, corpo e pensamento. Depois que estávamos impregnados dessas sensações internas, começávamos a imaginar o movimento do osso para, posteriormente, lançá-lo ao espaço.

Essas experimentações abrem campos impensados de movimentos e estabelecem novas percepções sensoriais e motoras. Ampliam a relação de equilíbrio e domínio do espaço. A abordagem somática dessa experiência é a Ideokinésis. ${ }^{40}$

Em 1996, Tica Lemos e eu fundamos a Cia. Nova Dança 4, um núcleo de pesquisa improvisacional. Assim, começamos estudando a composição cênica, o contato improvisação e o que chamei de "movimento-imagem-ideia",41, um fundamento para que o intérprete reconheça a imagem desenhada por ele no espaço. Nem sempre quem se movimenta reconhece o desenho da imagem projetada no espaço e sua leitura para quem vê. Vivenciar as sensações das imagens é fundamental. Para isso, as pausas são necessárias, sobretudo para reconhecer cada instante de movimento, suas imagens e sensações. A somatória desses "movimentos-imagens-sensações”, permeadas de pausas, oferece ideias, às quais podemos nos agarrar e por elas seguir, ou simplesmente descartá-las, para que outros e infinitos movimentos-imagens-ideias surjam. "Movimento-imagem-ideia" é o conceito como um todo, porém, ele é articulado em partes, por isso movimento-imagem-sensação. Para quem vê de fora (espectador), muito provavelmente consegue perceber o potencial da ideia. Porém, quem está na criação, na

\footnotetext{
${ }^{40} \mathrm{O}$ termo Ideokinesis surgiu no começo dos anos 1970, mas abordagem nasce muito antes com Mabel Todd (1880-1956) e foi desenvolvida ao longo do tempo por Barbara Clark (1889-1982) e Lulu Sweigard (1895-1974) e outros pesquisadores. É uma abordagem em que o córtex cerebral (parte consciente do cérebro), por meio de visualizações da estrutura óssea e seus deslocamentos, inicia novos padrões de atividade neuromuscular, a fim de organizar e equalizar o sistema muscular e esquelético para o movimento. Ideo (ideia) e Kinesis (movimento). http://www.ideokinesis.com/dancegen/dowd/dowd.htmh

${ }_{41}$ Pesquisadoras que foram minhas alunas, realizaram trabalhos acadêmicos de teses de mestrado e doutorado, que tratam do tema (MACHADO, 2000; 2005; MACARI , 2011).
} 
investigação interna, ainda não está na imagem. Isso em sentido pedagógico, pois, depois de muito treinar, esses elementos se integram.

Partimos da premissa de que em todo movimento há uma imagem, "movimentopausa-imagem”, subjetiva ou concreta, cotidiana ou estética. Resta, portanto, ao intérprete reconhecer e preenchê-la através da respiração, dando espaço à sensação. “Movimento-pausa-imagem-respiração-sensação-imagem-movimento..." em fluxos até chegarmos a uma ideia, ou apenas observar os potenciais de possíveis ideias. As pausas podem ser longas ou micropausas como o "fotograma de cinema", em que a imagem se completa sem vermos cada fotografia que constrói uma ideia. Esse aspecto deve ser treinado até que se torne orgânico, obtendo, assim, a comunicação de sua dança e gestos.

Percebo que essa proposição tem sido muito eficaz para o trabalho do improvisador, seja ele um intérprete da dança, do teatro, do universo do palhaço ou da narração. Identifico nela a influência da biomecânica de Meierhold, a precisão do desenho do corpo, as pausas, a necessidade de compreender cada instante de movimento, para ter a ação total. Em Meierhold, as ideias veem primeiro, como lançar a pedra ou a flecha, por exemplo, tendo, assim, toda a mecânica dessas ações por meio da lógica de movimentos e da sucessão de imagens previamente por ele determinada. No conceito que proponho, a ideia vem ao fim, como conclusão da trajetória do movimento, que é livre em sua criação, tendo presentes os elementos acima citados, entre outros. Philippe Gaulier, seu ponto fixo e os desenhos da commedia dell'arte também estimularam a criação do "movimento-imagem-ideia". Sua estruturação se deu ao longo do tempo, na somatória desses materiais aos estados meditativos, aos conhecimentos de consciência corporal, trazidos da técnica Klaus Vianna, por Neide Neves, e fortalecidos agora pela Ideokinésis e por estudos de movimentos, aprendidos com Tica Lemos.

No "movimento-imagem-ideia", um movimento leva a outro movimento naturalmente. A percepção do movimento criando imagens no espaço será observada tanto por quem produz o movimento como por quem o vê. A intenção é o reconhecimento da imagem interna que o intérprete produz, para o reconhecimento externo de quem o assiste, o espectador, ou seu parceiro, ou parceiros de cena, para que façam a leitura das imagens produzidas e, ao intuí-las, possam jogar. O ser humano se movimenta e entra em pausa inúmeras vezes na vida, por minutos, horas, dias e assim por diante. Esta é uma das chaves: pausar e sentir a respiração. A pausa é viva, o 
coração continua a bater, o sangue a correr, os órgãos a pulsar, o oxigênio a fluir; internamente, tudo se move, inclusive os pensamentos. O comando é: "Deixe o pensamento passar na sua mente". Ou então, o provoque, sem julgar. "Qual o próximo pensamento?" E, mais uma vez, deixe os pensamentos passarem e continue a observar a direção dos ossos: coluna, crânio, tíbia, fíbula, escápulas, rádio, una, pés. Durante a pausa, tente 'escanear' internamente o desenho do corpo, que aqui chamamos de imagem interna. Faça o mesmo por todo o corpo externo, rente à pele, a imagem externa. Ao reconhecer a imagem interna e externa, respire em preenchimento e observação, sem pressa de definição de que imagem é essa. Apenas pergunte a si mesmo, sem buscar respostas.

A conexão entre respiração e reconhecimento da imagem, em geral, nos leva a uma sensação que pode ser social, instintiva, abstrata, concreta ou até mesmo a memória de sensação corporal. Não se trata da memória psicológica, mas antes de memória do corpo. Ao identificarmos as sensações das imagens internas e externas produzidas por nossos corpos no espaço, temos o potencial de sermos lidos pelos outros. A intenção é comunicar, através do improviso, com o corpo no espaço.

"Um movimento que me leva a outro movimento, que me leva a uma imagem, que me leva a uma ideia". Um intérprete deitado no chão depois de um momento de relaxamento e introspecção para o aterramento, ou a sensação de enraizamento de nosso corpo no chão, deixando-o ser atraído pelo ímã do centro da terra, com vetores verticais aceitando a gravidade; a respiração consciente, profunda, para oxigenação do corpo, a recepção do toque (massagem) em um osso ou conjunto de ossos específicos, como a coluna ou as escápulas, ou a tíbia e a fíbula, por exemplo. $\mathrm{O}$ intérprete deve estar relaxado, porém, focado nas sensações do toque nos ossos, percebendo, imaginando sua forma, peso, coloração, vibração e potenciais direções de deslocamento, alinhando corpo e mente. Aí, então, começa sua investigação ${ }^{42}$ imaginando o movimento e depois o realizando no espaço, sempre com a voz de comando que o incita a se mover deixando o fluxo de movimento acontecer: de um movimento pedir outro movimento e deixar surgir pausas, os reconhecimentos das imagens pela respiração e a sensação do desenho do corpo pelo interno e externo, por tudo que toca o corpo, o ar, o chão, as paredes, o encostar a pele no outro e, quando esse

\footnotetext{
${ }^{42} \mathrm{O}$ parceiro que ofereceu o toque, a massagem, deverá ser um observador atento, de onde se inicia o movimento, se dos ossos trabalhados ou não, as subsequentes reverberações e criações de movimento desse corpo que pesquisa. A observação faz parte do aprendizado. Na sequência, os papéis serão trocados.
} 
toque acontecer, pausa. Reconhecer a interrupção, o quente, o frio, o susto - o sistema nervoso atuando. Essa primeira parte do exercício é sempre feita de olhos fechados, para que o sensorial se apresente de forma cuidadosa e expandida, aflorando as percepções. O pesquisador está nesse momento a quase cem por cento dentro de si mesmo, mapeando o espaço sensorialmente com todo o corpo. Um estado de introspecção. Aos poucos a voz que lidera a investigação, pede que se abra os $\operatorname{olhos}^{43} \mathrm{e}$ repete evoluindo nos comandos: "um movimento que me leva a outro movimento, que me levam a pausas, que me trazem sensações, que me levam a imagens, que me impulsionam ao deslocamento e a outros movimentos, a pausas, imagens e sensações que me levam a uma ideia". Imagino que todo movimento constitui por si só uma imagem, e se fotografarmos essa imagem talvez ela nos ofereça sentido, ou não. Quando fazemos a leitura objetiva de uma imagem, isso para mim, em princípio, se constitui uma ideia, mesmo que essa imagem seja abstrata. Existem imagens que são objetivas, outras subjetivas, cotidianas ou extracotidianas. O fundamental é o intérprete estar consciente da imagem que projeta no espaço e seu possível sentido ou leitura. Poderia também dizer que a ideia pode ser uma atividade ou um gesto, uma atitude, um aspecto emocional, ou ainda uma ação, ou frases de movimentos codificados que buscam significação ou apenas fruição, ou até mesmo o vazio. O intérprete deve estar presente na observação de cada instante de movimento, fotografando mentalmente a passagem de transformação do movimento e verificando as alterações das imagens e suas possíveis significações (ideias) ou não. As pausas são muito bem-vindas para essa compreensão. Assim, gosto de lembrar do "fotograma de cinema", no que tange a construção de múltiplos quadros, em que a somatória dessas imagens (fotografias) em movimento gera uma ideia.

A ideia é o último elemento a ser convocado por quem conduz o trabalho. Tudo deve começar no vazio, no corpo, em um sistema do corpo e sua relação com o espaço. A ideia é o fim, e não se deve prender-se a ela. Vê-la como potencial, um insight e deixar que um novo movimento conduza a um novo fluxo e revele novos potenciais de ideia, ou novas linhas de ideias. Esse é o treinamento. O movimento somado à imagem e sua sensação constrói uma ideia. A sucessão desse fluxo em micro e macroideias constrói a cena. O desenvolvimento desse sistema trouxe maior capacidade de

\footnotetext{
${ }^{43}$ Os olhos devem se abrir em porcentagens pequenas para o externo. Nossa atenção interna deve estar em equilíbrio com o externo. Digo sempre para estarmos cinquenta por cento dentro de nós (reconhecendo as imagens internas) e cinquenta por cento para o mundo externo e sua comunicação.
} 
improvisação aos nossos trabalhos. De alguma forma, quando encontro Tica Lemos e seus estudos do corpo é como se revelasse e adensasse os conteúdos improvisacionais que estavam sendo trabalhados em meus procedimentos teatrais. Mas os vocabulários eram outros, por exemplo: "O ator deveria estar atento às reações corpóreas, aos pensamentos e vice-versa, onde a ação física pudesse suscitar imagens, assim como essa suscita ações". São palavras por mim utilizadas no processo de O Rei de Copas, como relatado nesta dissertação, anteriormente, e que, ao manter contato mais profundo com a dança, expande-se, trazendo luz aos meus processos da construção da improvisação e da interpretação, compartilhada em tempo real com o público.

\subsection{BMC e Entradas e Saídas}

Conhecer o Body-Mind Centering (BMC) ${ }^{44}$ fechou um ciclo de entendimento. Primeiro foi o contato com Pol Peletier e suas conexões entre glândulas, articulações e chacras, depois Tica Lemos com a Ideokinésis e a respiração sokushin kokiu ho, prática das artes marciais, como o Aikidô, traduzida literalmente como "respiração pelos pés". $\mathrm{O}$ BMC veio paralelamente aos primeiros contatos com o estúdio, com a vinda de Francis Savage. $^{45}$

Fazer o curso com Savage trouxe o resgate aproximado do trabalho que havia acontecido comigo em relação a Pol Peletier, pois ela trabalhava com as glândulas e as articulações, falava do preenchimento do corpo, do relaxamento, das massagens, de ocupar o espaço sensorialmente, do aterramento (grounding). Francis, por sua vez, fazia essas mesmas aproximações, mas o foco de atenção para o movimento, naquele workshop, era pelos órgãos. Observar o mundo a partir das sensações orgânicas do corpo abriu fronteiras novas do deslocamento, do deslizamento, do peso, do contato, da

\footnotetext{
${ }^{44} \mathrm{O}$ BMC (Body-Mind Centering) é uma abordagem somática criada pela americana Bonnie Bainbridge Cohen no fim dos anos 1960, que propõe, a partir do estudo do movimento e de princípios de anatomia e fisiologia, a corporalização (embodiment) dessas estruturas e processos, ou seja, a apropriação de como isso tudo acontece no meu corpo/mente. O principal material desse estudo são os sistemas do corpo (esquelético, muscular, orgânico, fluido, endócrino, nervoso, etc.) e também os padrões neurocelulares básicos (padrões de movimento que todos nós, seres humanos, construímos durante nosso desenvolvimento e que constituem a base de nossa coordenação motora). Perceber nosso corpo/mente através destas múltiplas perspectivas nos possibilita novas formas de percebermos a nós mesmos e ao ambiente que nos cerca, encontrando novas respostas para as perguntas que esse ambiente não cessa de produzir. (Tarina Quelho, professora licenciada desta abordagem, responsável por este conteúdo em minhas pesquisas e criações)

${ }^{45}$ Dançarino americano, professor de contato-improvisação e BMC (Body-Mind Centering).
} 
presença, do relaxamento; da observação da pulsação de cada órgão e sua relação com as articulações. Tomar consciência de fato da localização de cada um, seus sons e o entendimento, mesmo que ainda superficial, de suas funções. Naqueles dias aconteceram novas percepções de vida, de qualidade de movimento, de sensações, de emoções e de insights para a utilização desses conhecimentos no jogo de interpretação e improvisação.

Ao trabalhar os órgãos, ficou muito perceptível a relação da emissão do ar e do som. Um universo paralelo que, em verdade, é corpo. A descoberta de como trabalhar a voz de forma orgânica, retirando a força e as tensões da garganta. Outros aspectos do corpo vibram o som. A emissão da voz, ganhando espaço de maneira lúdica e orgânica através da reorganização dos padrões de movimentos, ampliando conexões e dando estímulo para as investigações.

Yoshi Oida, em seu livro $O$ Ator Invisível, nos propõe imaginar a visualização de outras partes do corpo exercendo a função de respiração, sugerindo a respiração pelos poros, pela pele, ou pelos pés, como o próprio Aikidô e cita um ditado: "Pessoas comuns respiram pelo peito, pessoas sábias, pelo hara, e pessoas treinadas, pelos pés" (2007, p. 118). Deleuze e Guatarri, em O Corpo Sem Órgãos, dentro do contexto de experimentações extremas, concebem questões como: "por que não caminhar com a cabeça, cantar com o sinus, ver com a pele, respirar com o ventre...” (1996, p. 11). Trata-se da liberdade de observar os órgãos e os sistemas do corpo como um terreno de experimentações, nos valendo desse instrumento pleno, não apenas com suas funções orgânicas objetivas, mas examinando sua forma, localização, pulsação, suas relações com outros órgãos, articulações e membros, explorando potenciais físicos muitas vezes desconhecidos. As primeiras ocasiões em que ouvi Tica Lemos dizer que iria "dançar com os rins", julguei ser essa uma afirmação extravagante, mas hoje sei que essa possibilidade é totalmente possível, deixando que a dança, o movimento, se estabeleça a partir da sensação orgânica dos rins, ou do coração, dos intestinos - cada um trará dimensões diversas aos sentidos dessa dança, movimentação ou interpretação. Em aula, para meus alunos, gosto de dizer que nosso corpo é como um playground, um verdadeiro parque de diversões, para que se deixem experimentar com amplitude, com o espírito curioso e livre da criança, que brinca e descobre inusitadas variações de si mesmo.

Ao lidar com cada conjunto de ossos ou órgãos, percebia as diferenças de qualidades de movimentos, de sensações, de emoções, fazendo surgir distintas intenções 
nos desenhos corporais. Qualquer osso ou órgão trabalhado causará reverberações por todo o corpo, fazendo os outros ossos, órgãos e outros sistemas se adequarem para estabelecer o equilíbrio ou, ao contrário, para deixar que o desequilíbrio do corpo seja bem acolhido na estética de movimento que se deseja.

Paralelamente a essas descobertas e estudos, recebemos a improvisadora, americana, residente em Amsterdã, Katie Duck, que possui papel fundamental entre pesquisadores de improvisação brasileiros, por sua esclarecedora maneira de estruturar as entradas e saídas do improvisador em cena. Uma de suas máximas, mais valiosas para mim, é: “o improvisador entra em cena para sair". Ao entrar, algo pode acontecer no meio do caminho, do espaço cênico, então se dá vazão a esse acontecimento e logo se vai em direção a saída. No momento da saída, um sinal pode lhe trazer a chance de ficar mais um pouco em cena, mas seu objetivo é novamente a saída. Deve-se entrar no espaço vazio, sem uma ideia pré-concebida do que fazer na cena. A escuta e o olhar da leitura da cena devem ser aguçados e treinados. Não se entra na cena por desejo, se entra por um sinal concreto, um pássaro que canta, uma porta que se fecha, alguém que sai de cena, um braço que levanta, um acontecimento, um sinal, que o empurra para a cena. Tudo acontece no tempo, nem antes nem depois. O jogo se estabelece. Havia também as saídas de dentro da cena, pausas longas de aterramento profundo, em que aquele corpo pausado parece fazer parte do cenário, ir ao centro da terra, ali ficar e, por um novo sinal, "entrar", ou voltar do centro da terra, voltar à cena e ao movimento, para novamente sair para as "coxias" ou para um novo aterramento. Fizemos aulas com Katie Duck no Estúdio Nova Dança e a acompanhamos a Minas Gerais, onde acontecia o Festival de Artes de Ouro Preto. Lá demos continuidade a esse aprofundamento nos ensinamentos das entradas e saídas.

O Estúdio Nova Dança era muito ativo na produção da vinda de artistas e pensadores da dança, fossem eles brasileiros de outros estados do Brasil ou que residissem em outros países, ou ainda estrangeiros que nunca tivessem vindo ao nosso país. Bebemos de fontes preciosas de pesquisadores da dança, como Steve Paxton e Lisa Nelson, que vieram a ser uma referência para toda uma geração dança no Brasil e principalmente para nós da Cia. Nova Dança 4, influenciando nossas pesquisas e criações. 


\title{
5. Capítulo IV - A Improvisação e a Cia. Nova Dança 4
}

\author{
A palavra e o corpo \\ A dança e o teatro \\ A palavra leva o/ao corpo \\ O corpo leva o/ao teatro \\ O corpo é palavra é voz \\ Palavra é pensamento \\ Pensamento é corpo \\ Pensamento toma voz \\ Pensamento toma o corpo \\ A voz sai do corpo \\ A palavra adentra o corpo \\ Corpo é dança é espaço \\ Palavra é dança no espaço \\ Espaço é vazio \\ Espaço é vazio preenchido pela palavra e pelo corpo \\ A palavra a princípio é teatro \\ A palavra constitui e conceitua a dança \\ A dança é do corpo \\ A dança é corpo \\ O corpo imagina e dá imagens ao teatro articulando palavras
}

Na Cia. Nova Dança 4 foi criada uma relação de aprendizados durante todo seu o percurso, sempre nos fazendo questionar quais desafios iríamos empreender para o entendimento da improvisação em tempo real frente ao público. Vários foram os trabalhos realizados e as pesquisas desenvolvidas pelo grupo. Nesta dissertação, serão apresentados alguns desses caminhos, porém abordarei mais detalhadamente o processo de $O$ Beijo, que faz parte da Trilogia Influência.

Começamos a companhia com um grupo de pessoas mais experientes no teatro e na dança: Luiz Ferron, Wilson Aguiar, Lena Whitaker, a jovem Lívia Seixas, o músico Renato Consorte, além de Tica Lemos, que orientava a pesquisa do pensamento corporal, enquanto a elaboração da investigação e a direção ficavam sob meu olhar. Estávamos lidando com a improvisação na intersecção de linguagens entre a dança e o 
teatro. Naquele momento, no ano de 1996, esses elementos juntos eram novidade para todos nós, e nós deveríamos mergulhar no processo de modo vertical e para isso precisávamos de muito tempo, dentro da sala de ensaio, pesquisando. Esses artistas que nos acompanhavam, até por serem atores e bailarinos profissionais, com compromissos familiares, eram requisitados para outros trabalhos e não podiam estar dedicados em tempo integral. Sem remuneração era difícil o envolvimento pleno, apesar de estarem envolvidos. Assim, depois de alguns meses, apenas Tica, Lívia e eu continuamos a pesquisa. Renato Consorte, violonista e guitarrista permaneceu, mas sua presença era mais esporádica.

Tica e eu, trocávamos conhecimentos, por meio das aulas que oferecíamos para o público do Estúdio Nova Dança e nas salas de ensaio, com nosso pequeno grupo. As aulas eram extensões de nossa pesquisa, nas quais aplicávamos nossas descobertas, investigando em outros corpos aspectos por nós trabalhados nos ensaios. Assim, observávamos alunos potenciais para fazer parte de nossa pesquisa e que pudessem se dedicar integralmente. Surgiram: Alex Rato e Diogo Granato. Trabalhamos com os quatro no elenco, em experimentações em sala de ensaio ou pelos espaços do estúdio, ou às vezes na escadaria do Bixiga, para experimentar e performar frente aos transeuntes. Elaborávamos um trabalho diferencial naquela época e cheio de tentativas, de acertos e de erros, ainda mais por se tratar de improvisação. Nesse sentido, o trabalho do palhaço sempre nos ajudou, pois um "erro pode ser um acerto", e se o estado de presença estivesse muito alinhado, o que seria um desastre, poderia causar riso e novos desdobramentos. Além de ensaiarem, todos frequentavam nossas aulas de contato improvisação, de palhaço e de dança-teatro, que Tica e eu oferecíamos. O jogo teatral permeava todos os processos.

No segundo semestre do mesmo ano de 1996, fui convidada para dirigir uma turma de alunos na Escola de Arte Dramática/EAD/ECA/USP. Lá propus a realização, pela primeira vez, de um espetáculo de improvisação em tempo real, que reunisse o contato-improvisação, o jogo teatral e o palhaço. Tica Lemos e eu preparamos intensivamente os 24 alunos $^{46}$ e trabalhamos sem tema, apenas com o jogo improvisacional de entradas e saídas, idealizado por Katie Duck e por nós apropriado,

\footnotetext{
${ }^{46}$ Em Prelúdio, encontrei parcerias como Marat Descartes e Gero Camilo, com quem realizei Aldeotas, em 2003; Cristiano Karnas, que veio a ser intérprete da Cia. Nova Dança 4, além de: Andréia Bassit, Cláudia Missura, Eugênio La Salvia, Fabiana Gugli, Luciana Carnielli, Luciano Bortoluzzi, Nando Bolognesi, Paula Cohen, Tatiana Thomé.
} 
no qual as regras básicas eram: entrar para sair, entrar no vazio sem uma ideia premeditada e reconhecer que o movimento está no espaço. Os alunos tinham a opção de entrar na cena com ou sem a máscara do palhaço. Quando entravam com a máscara, jogavam as relações dos encontros com outros palhaços e com a plateia. Quando entravam sem a máscara, executavam composições, delineando geometrias espaciais ou dançando a dança de contato. No trabalho, Prelúdio para Clowns e Guitarra, inserimos Renato Consorte como um provocador da cena através da guitarra. Só esse instrumento, inspirando movimento, frisando comicidade, fazendo transições de cena e provocando suas rupturas quando necessário. Por meio desse espetáculo, ratifiquei: o palhaço é um grande aliado da improvisação e o "movimento-imagem-ideia" é uma realidade improvisacional.

No primeiro espetáculo da Cia. Nova Dança 4, Um Passeio ao Jardim (1998), em sua versão inicial, a vivacidade e criatividade não duravam mais que vinte minutos. A ansiedade muitas vezes faz com que aceleremos os processos criativos, diante do público. Porém, em um segundo momento, numa pequena temporada de quatro dias na Sala Jardel Filho do Centro Cultural São Paulo, conseguimos um maior aproveitamento de nossas condições de comunicação, compreendendo melhor a questão do tema, onde o universo de criação era o imaginário contido na atmosfera de "um passeio ao jardim", identificado como o nome do espetáculo. A estrutura se dava como se fosse um canovaccio, iniciando com as apresentações das personagens, para nós chamadas de "quem", por não serem personagens tradicionais, mas sim os próprios intérpretes com suas características pessoais, em solos, lidando com as imagens, o espaço, as sensações, as ideias, as emoções construídas e vividas por eles em tempo real, diante do público. No segundo momento, se davam os encontros e suas relações; primeiro os duos, depois os trios; seus desenvolvimentos explorando encontros, desencontros (aproximação e distanciamento), até chegarmos ao quinteto ${ }^{47}$, onde uma dança coletiva de conexão se constituía, com a sensação de que todos estão no mesmo universo, até dissolverem essa imagem coletiva. A iluminação finalizava o espetáculo, dando blackout; a música era operada por mim, o que de alguma forma me colocava como atuante, na dinâmica do trabalho.

A ideia era fazer com que o público, de início, ficasse em dúvida se o espetáculo era improvisado ou não. Buscávamos ser precisos mesmo improvisando, para dar a

\footnotetext{
${ }^{47}$ Agora eram cinco intérpretes em cena: Tica Lemos, Lívia Seixas, Diogo Granato, Alex Ratton Sanches e Cristiano Karnas, que vinha da experiência do espetáculo realizado na EAD/ECA/USP.
} 
ilusão de realizar composições bem alinhadas de um espetáculo acabado. E apenas ao final revelávamos ao público que se tratava de improviso, o que, em geral, causava surpresa e fazia com que muitos espectadores assistissem novamente à apresentação, para verificar se era, de fato, improvisação. Certamente viam outras composições, outras tomadas de decisões e outras imagens, sobre a mesma relação temática.

Com maior precisão e maturidade aconteceu Acordei Pensando em Bombas, segundo projeto da Cia. Nova Dança 4. Em palco italiano, realizávamos uma relação quase clássica da estrutura de composição, no ato de explorar o espaço cênico. Para criar "ilusões coreográficas", de forma proposital, os intérpretes, através de treinamento dos mais variados, criavam composições, incluindo uníssonos em tempo real, dando a impressão ao espectador de que aqueles movimentos foram estruturados e fixados previamente. A sintonia conquistada pela pesquisa e pelos treinamentos continuados fortalecia o entendimento, a escuta e as tendências de caminhos organizativos de todos os envolvidos, mesmo que em alguns instantes se instaurasse o caos, para em seguida vir nova ordem. Em Acordei Pensando em Bombas, as questões sociais e políticas eram nossa temática. O ano era 1999, e a situação política de São Paulo era bastante difícil, havia inclusive um adesivo para se colocar no carro com os dizeres: "Eu tenho vergonha dos vereadores de São Paulo". As crises e rebeliões na Febem ${ }^{48}$ eram numerosas e, por várias vezes, os noticiários de televisão passavam imagens com gritos horríveis dos meninos, internos, em guerra com a própria instituição. Resolvemos dançar essas questões, entre outras. Eu gravava o material de noticiários da televisão, assim como, de documentários, entrevistas. Essas sonoridades eram colocadas como trilha sonora ${ }^{49}$, misturadas à poesia da música popular e instrumental brasileiras, além de silêncio. Os atuantes improvisavam essas circunstâncias e essas poéticas, indo em direção a elas, sublinhando-as ou, ao contrário, criando oposições. A intenção era construir comunicação através da dramaturgia do corpo, procurando traduzir esteticamente questões que permeiam a condição humana, tendo como partida o universo urbano paulistano.

\footnotetext{
${ }^{48}$ Fundação Centro de Atendimento Socioeducativo ao Adolescente. Hoje essa instituição leva o nome de Fundação Casa - Fundação Centro de Atendimento Socioeducativo ao Adolescente.

${ }^{49}$ Havia muitas "vinhetas" ou faixas dessas sonoridades gravadas em dois CDs, umas mais longas, outras curtas, sobre os temas acima aludidos, entre outros. Eu operava como DJ, sobrepondo músicas e falas e escolhendo os caminhos temáticos do dia, na observação das escolhas improvisacionais dos intérpretes ou mesmo fazendo provocações. A mesa de operação de som, assim como de luz, criada e operada por André Boll, ficavam na plateia, muito próximas do palco, para que pudéssemos sentir a performance como atuantes.
} 
Nosso tema era trazer esse ato de revolver, de revolucionar, no corpo, nas articulações, na coluna, na dança. Conjugávamos a isso a frase poética "Repetir repetir até ficar diferente", de Manoel de Barros (2010, p. 300), ajudando na construção de gestos, de movimentos, que, combinados ao "movimento-imagem-ideia", suscitavam figuras que nos remetiam a manifestantes e opressores. Como sempre, a completude de compreensão da imagem viria posteriormente ao caminho do fluxo do movimento. Cristian Duarte, que agora fazia parte da companhia, em dado momento com os pés bem fincados no chão, começava um pequeno movimento em torno de seu próprio eixo. A reverberação do movimento, a partir dos pés aterrados, subia pelas articulações das pernas, do quadril, da coluna, do crânio; o corpo querendo continuar o movimento de subida da energia além do topo da cabeça provocava o levantar dos braços ao mesmo tempo. Ao reconhecer a imagem, o bailarino cerrava os pulsos e brincava com a imagem/ideia do "manifestante", daquele que se rebela, que ultrapassa o limite da irritação, trazendo no corpo o ato de revolver articulações, sem intenções, ou dramaticidades, apenas em dança.

Convidei Rubens Rewald, como dramaturgista, para nos orientar com leituras e a compreensão de conceitos. Ele nos indicou os textos: $O$ Beijo de Lamourette $^{50}$, estudo sobre a Revolução Francesa, e trechos de textos de A Poética do Espaço ${ }^{51}$, ambos com focos divergentes: um construindo um imaginário de situação violenta e sanguinária; outro, que sem nos afastar do medo e da angústia, nos envolvia nas reminiscências da intimidade e da ludicidade, fortalecendo a imaginação para que ela desse lastro à realidade. Esses estudos proporcionaram preenchimento às imagens e intenções de movimentos, de modo a dar campo à dramaturgia do intérprete no improviso, capacitando-o a produzir, em cena, composições, estruturas coreográficas imponderáveis. $\mathrm{Na}$ época, o preconceito com a improvisação ainda era grande, mas a comunicação começava a se efetivar e o público se engajava no jogo improvisacional, onde a sensibilidade, a escuta e o treinamento de todos os atuantes convidavam a um espetáculo único a cada noite, como uma obra aberta e mutante.

Partimos, então, de uma forma mais clássica, em palco italiano, para a pesquisa de espaços não convencionais, ao explorar a arquitetura da cidade e de outros espaços, dançando entre os transeuntes ou desaparecendo entre eles. Nesse sentido, o projeto

\footnotetext{
${ }^{50}$ De Robert Darton (O Beijo de Laourette: mídia, cultura e revolução, tradução Denise Bottmann. São Paulo: Companhia das Letras, 2010, p. 22-39.)

${ }^{51}$ De Gaston Bachelard (A Poética do Espaço. São Paulo: Martins Fontes, 2000, cap. 1 e 2.).
} 
Passeios se estabeleceu como uma série, ao colocar nossos corpos em relação à arquitetura, evidenciando-a no cotidiano. Tomar de assalto sem balburdia, invadir respeitando limites, abrir territórios, inventar expansões de renovadas atitudes dentro de lugares ordinários, cuidar dos espaços entre nós, dos outros e das coisas. Nos inseríamos no cotidiano de uma área, nos misturando aos frequentadores do local. Aos poucos, íamos nos diferenciando por nossas atitudes não convencionais, pela estranheza, sempre buscando não ser invasor, mas parte, nos integrando ao lugar. Intencionávamos provocar o questionamento do olhar e do comportamento cotidiano e suas potenciais rupturas poéticas. Nossa capacidade de assimilar a composição junto ao espaço (agora cenário) e aos transeuntes criava, afirmava e reinventava diversas construções coreográficas do cotidiano, essencialmente voláteis. Para um olhar atento, que estivesse ali para assistir ao evento, ou que descobrisse seu entorno e percebesse o jogo que transcorria, seria capturado para dentro da brincadeira. Se acontecesse a participação espontânea por contágio, seria muito bem-vinda e assimilada. Nunca propus a convocação imposta ao público ou transeuntes por parte dos nossos intérpretes, sempre pedi e preferi a sutileza.

O movimento que deu origem à série chamou-se Águas de Março sob Lina Bo Bardi, de 1999. Chegávamos ao Sesc Pompeia com roupas cotidianas, alguns com mochilas, em absoluta normalidade, cumprimentando amigos ou olhando as exposições que ali aconteciam. Conscientes do espaço de convivência interna do Sesc Pompeia, onde há uma área recortada por um riacho de pedra, os intérpretes deveriam estar atentos aos parceiros de cena e às pessoas que ali passeavam ou jogavam cartas, e sutilmente estabeleciam composições, valorizando os detalhes arquitetônicos elaborados por Lina Bo Bardi. Um desenvolvimento longo de performance. Conhecíamos cada detalhe do lugar, pois havíamos estado na convivência dias antes para observação de seu cotidiano e seus frequentadores, tendo em vista nosso objetivo: entender $\mathrm{o}$ funcionamento do ambiente e sua organicidade, para fazer parte. Nesse ensaio observatório, a máxima era: "performar sem performar", ou observar imaginando a movimentação e seus potenciais in loco, andando por ali, parando, sentando, imaginando-se dançar e correr; analisar os impulsos para, no dia da apresentação, agir. Durante o horário noturno, após o fechamento da unidade, fizemos, ainda, um ensaio no espaço vazio, sem a presença de público ou funcionários. Aí sim, dançamos, criamos composições, dinâmicas, colocamos em prática nossos treinamentos de conexão, de reconhecimento de espaço, toda nossa técnica improvisacional, para entender a 
espacialidade, mas sabíamos que com o público o lugar se transformaria.

O roteiro: chegávamos individualizados, construíamos encontros em variados lugares do espaço, até nos configurarmos como "coletivo em dança", levando sempre em conta as variantes oferecidas pelos deslocamentos e atitudes do público ou mesmo dos funcionários. Questão importante: jamais criar um pequeno personagem, mas agir como pessoa, bailarino, performer que se é, dando dimensão aos estados emocionais que surgirem, e se houver necessidade, dar vazão a eles. Foi um verdadeiro jogo nos dois dias consecutivos em que ali estivemos. Era possível ver em algumas pessoas do público a vibração no olhar. Fizemos Passeios em praças, prédios, invadindo piscinas, em avenidas, em parques, em múltiplos espaços. Nosso treinamento inicial se deu na Praça da Sé - aliás, lá fizemos boa parte de nossa pesquisa.

Então, criamos Palavra, a Poética do Movimento (2002) ${ }^{52}$ com o intuito de dar vazão ao fluxo da voz do bailarino e também na intenção de estender nossa compreensão das induções da palavra como conceito de dança. Ao mesmo tempo, investigávamos práticas do corpo, buscando as melhores condições de emissão da voz e sua articulação em palavra, para que textos pudessem ser expressos pelos bailarinos em movimento, ao dançar contato e improvisação, em voos, giros, pausas, com corpos que pressionam uns aos outros em carregamentos, indo ao chão em rolamentos, ou caindo de forma imprevisível, sendo a coreografia não pré-definida.

Para nós, nessa pesquisa, o propósito eram as rupturas. Não queríamos a linearidade, uma história contada do início ao fim, ou estruturas coreográficas clássicas ou textos de teatro. Falaríamos em cena os textos filosóficos articuladores de nossa dança, criaríamos diálogos com eles em tempo real, sem os formalizar em um texto dramatúrgico prévio.

Deixamos o silêncio da palavra na dança para criar Palavra, a poética do movimento, processo em que o texto não era só instigador do movimento e da composição, mas passava a ter voz, a ser dito pelos intérpretes. Textos como Corpo sem órgãos, Mil Platôs, de Deleuze e Guattari, O Homem Cordial, de Sergio Buarque de Holanda, Ética, de Spinoza, e as obras estudadas em Acordei Pensando em Bombas. Esses textos discutidos conceitualmente começaram a ser apropriados, repetidos e emitidos pelos intérpretes em cena. Criamos, desse modo, a noção de compêndio ${ }^{53}$, em

\footnotetext{
${ }^{52}$ Érica Moura e Gisele Calazans entram para o elenco da Cia. Nova Dança 4.

${ }^{53}$ Compêndio: um conjunto de textos de várias origens ou a compilação em que se encontra o mais essencial de um estudo.
} 
que compilávamos conceitos, pensamentos, palavras, frases, parágrafos a serem apreendido por todos, contidos nos textos propostos. Esses trechos de textos eram escolhidos dentro do compendio estudado, por cada intérprete, para que a singularidade do seu discurso aparecesse na cena. Todas as palavras a serem articuladas no momento da cena deveriam estar contidas no compêndio - e deveriam ser evitados os depoimentos pessoais, construídos por palavras fora do compêndio. Por outro lado, o intérprete poderia construir um depoimento utilizando-se dos recursos do conjunto de textos. Esse artifício foi desenvolvido para a criação de um vocabulário comum, reflexivo, que ao mesmo tempo ampliava a expressão dos intérpretes, no que diz respeito ao conhecimento, à elaboração do pensamento e da linguagem. Um compêndio, um conjunto de textos, um vocabulário comum, a ser sabido, articulado, para ser dito em diálogos da cena, ou rápidos solilóquios, ou curtos monólogos. As repetições, também eram bem-vindas, assim como as sobreposições de falas, desde que elas fossem emitidas no sentido do compreender, para si mesmo e para o outro.

Entre os desafios de Palavra, a Poética do Movimento estava conseguir dançar e falar ao mesmo tempo, de maneira orgânica, inclusive na dança de contato, quando o corpo usa pressão e força para se manter em dança e equilíbrio. Para dançar e falar sem perder a emissão das palavras e ter expansão da voz, recorremos aos estudos e à prática do BMC - Body-Mind Centering, técnica cujo poder de acionar o corpo em sua integralidade se dá por meio do toque e da massagem nos órgãos, ou nos ossos e ou nas articulações, ou em outros sistemas, como já vimos anteriormente, permitindo a experiência da emissão do som e da palavra pela sensação dos órgãos, da vibração dos ossos e das articulações, ajudando no fluxo de movimento e das pausas. Os textos eram ditos de maneira reflexiva e repletos de diálogos improváveis, que ampliavam os sentidos. Muitas de nossas regras, estratégias, estruturas coreográficas, movimentações e falas eram geradas pelos textos de Deleuze e Guattari, O Corpo Sem Órgãos e Mil Platôs, que faziam parte do "jogo de compêndio".

O conceito do "jogo de compêndio" foi desenvolvido tanto para compreensão de texto, quanto para criação de conexões inexistentes entre textos diferentes, ou de partes diferentes de um mesmo texto. Ou ainda, para explorar as intenções dos textos, das frases e dos diálogos, refinando a escuta dos jogadores. Transformar as palavras dos textos em suas próprias palavras, torná-las orgânicas e, se for necessário, reorganizá-las para sua comunicação. O texto, da maneira como vejo sua emissão, deve ser dito de forma que pareça natural, quase uma conversa, para que chegue aos nossos ouvidos com 
maciez, fazendo com que a palavra e sua imagem adentre a imaginação, com todas as dinâmicas, sua musicalidade, sua poesia, de forma objetiva, mas sem ser dura, para que se compreenda todas as palavras, sem ser didático ou articulado de modo artificial. Manuel de Barros novamente nos ilumina com sua simplicidade e sabedoria: "Não pode haver ausência de boca nas palavras: nenhuma fique desamparada do ser que a revelou" (2010, p. 345). Esse é o ideal para mim: que o intérprete desenvolva a escuta, de maneira que as palavras e suas imagens cheguem ao outro (jogador e espectador) por volume dilatado, através da consciência corporal, do aterramento do corpo e de sua expansão no espaço. A elaboração da palavra em meu processo se aproxima ao mecanismo do corpo, mesmo porque voz é corpo, assim como palavra é mente e mente é corpo. As palavras constituem imagens e devem ser compreendidas pelo intérprete, vivenciadas na imaginação (por seu signo, conceito, memória, sensação) e degustadas nos lábios e na boca. O corpo do intérprete deve estar relaxado, mas vivo, sensível, poroso, respirado, para a troca com o ambiente e sua comunicação. Porém, por mais que nos esforcemos para fazer com naturalidade e organicidade, a palavra na cena poderá ter dificuldades de se dar sem artifícios, pois a cena, por mais orgânica que seja, apresentase ao público, torna-se social e, por isso, tende ao artifício.

Palavra, a Poética do Movimento desmistificava assuntos teóricos complexos, tomando para si um lugar simbólico de simplicidade ao tratar desses temas misturados com poesias, estabelecendo uma aproximação com o público, criando intimidade, fazendo do cliente um amigo. A ruptura da estrutura aristotélica, por meio do rizoma, cria redes de conexões, sem começo, sem meio, sem fim, apenas estabelece territórios, para logo em seguida desfazê-los, convidando à ação, ao caminho. A extensão do espetáculo era horizontal, sempre com a criação de novas linhas de conexão; quando alguma cena buscava o aprofundamento, logo um corte se dava para nova constituição de ideia e movimento, reestabelecendo um mundo novo, um jogo de horizontalidades. No princípio, era difícil de jogá-lo, pois nossa tendência era estruturar começo, meio e fim. Houve um momento na criação que nada se estabelecia, ou criava territórios de conexão, aconteciam atropelos, apenas se cortava o outro, as imagens, as palavras e a esquizofrenia dominavam, até que os treinamentos do corpo, da palavra, do compêndio, do entendimento dos procedimentos e dos conceitos, se tornavam imanentes. $\mathrm{O}$ propósito dessa estratégia foi apropriado, por nós, como uma segunda pele.

Realizávamos o Palavra em geral em palco italiano, mas não o utilizávamos de modo convencional, já que para nós todo o teatro era nosso palco. Incluíamos plateia, 
escadas, varandas, cabines, às vezes as portas se abriam e o hall, passava a fazer parte. Mesmo que o espectador não tivesse visão do intérprete, ele continuava em dança; o espectador o ouvia, ou até poderia se deslocar de sua poltrona, para vê-lo. Na mesma sintonia dos bailarinos, estavam os músicos, alguns com mobilidade maior, pela facilidade de locomoção do instrumento. Claudio Faria, nosso trompetista, era um deles. Com a sonoridade do trompete, direcionado ao corpo do intérprete, modificava a exploração e a qualidade de movimento deste. Faria esteve conosco praticamente desde o princípio. Em Acordei Pensando em Bombas, fazia participações especiais, mas nessa pesquisa estava cada vez mais próximo. Montamos uma banda, pois o desejo era trazer a palavra na música e ver como se dava o mesmo tipo de jogo, articulado como compêndio, agora musical. Contávamos com: Tata Fernandes e Natália Mallo no violão, voz e composição; Lelena Anhaia no baixo elétrico, voz e composição; Celso Nascimento na percussão; e Marcelo Munari na guitarra. Os músicos tinham um leque de canções possíveis, muitas delas vinham da influência de Itamar Assunção, ou composições próprias. Como a estrutura musical se dava nos mesmos moldes do trabalho de superfície do rizoma, de fluxos e cortes, novas linhas musicais foram criadas, seguindo caminhos de sobreposições musicais ou criações improvisacionais, a partir do compêndio e do que se estava dizendo em cena. A banda também era exposta às regras dos jogos propostos. A música teve papel fundamental. E depois nos acompanhou na feitura de outro espetáculo: Experimentações Inevitáveis Antropofágica 3.

Vontade de contar histórias, essa perspectiva sempre esteve de alguma forma em nossos trabalhos da Cia. Nova Dança 4, e ela se fortaleceu e tomou corpo em Experimentações Inevitáveis - Antropofágica 3, gestado entre 2006 e 2007, durante o projeto denominado Série Antropofágica. Esse espetáculo tinha como tema o livro autobiográfico de Marilena Ansaldi, Atos: Movimentos na Vida e no Palco (1994), no qual, através de sua trajetória pessoal e artística, ela traça a história da dança, do teatro e da dança-teatro na cidade de São Paulo nos anos 1960, 1970 e 1980. Às palavra e ao movimento somávamos as experiências de Marilena, as nossas próprias vivências pessoais e artísticas. Com depoimentos pessoais criados em tempo real, dançávamos e falávamos sobre o Estúdio Nova Dança, nos anos 1990 e 2000, discutindo se o que fazíamos era dança ou teatro.

Esses fluxos de trajetórias tinham como suporte estético jogos improvisacionais oferecidos por Lisa Nelson, que havia vindo dos Estados Unidos nos oferecer 
ensinamentos de seus estudos de composição, os quais foram antropofagicamente devorados, digeridos e integrados aos nossos conteúdos e aos de Marilena e transformados em Experimentações Inevitáveis - Antropofágica 3.

Nessa mesma Série Antropofágica, um pouco antes da vinda de Lisa Nelson, recebemos, na finalização do Estúdio Nova Dança, Steve Paxton para realização de estudos e do espetáculo Antropofágica 2 ou Coexistência, apresentado no Sesc Consolação (nele não havia falas, apenas dança). Steve nos perguntou o que queríamos dançar, e nossa vontade era dançar o fechamento do estúdio. Por isso, levamos pequenos elementos básicos que nos lembrassem uma sala do estúdio ou o terraço de grandes festas e encontros - deveríamos constituir um caminho que nos desse a sensação de uma história contada. Passamos longe dessa tentativa formal, mas perto de um momento essencial de encontro com um mestre e um público cativo. Assim, essa coexistência nos levou a sermos, apenas em movimento de dança, contadores de histórias.

Assim, a Trilogia Influência se estabelece pela simples vontade da Cia. Nova Dança 4 de contar histórias em dança.

\subsection{Trilogia Influência}

Inspirado em O Beijo no Asfalto, de Nelson Rodrigues, O Beijo (2009), da Cia. Nova Dança 4, é o segundo espetáculo da Trilogia Influência. Queríamos contar histórias, sem dizer palavras; construir nossa corporeidade por meio de diálogos, situações e rubricas contidas na Tragédia Carioca, contada por Nelson Rodrigues.

O teatro entrou nessa pesquisa de forma a instigar a dança, como o indutor desse acontecimento em movimento. Estávamos em busca de um texto que contasse uma história linear e profunda, que fosse clássico, que tivesse relações intrincadas, em que o suspense fosse presente.

Nossos estudos na trilogia e em boa parte de nossa trajetória de Cia. Nova Dança 4 pretendiam oferecer à improvisação a capacidade de construção dramatúrgica do espetáculo, que se reinventava a cada noite, na frente do público. Usávamos de estruturas ou estratégias que se transformavam em jogos de descobertas para quem fazia e para quem assistia. 
A investigação de $O$ Beijo era verdadeiramente uma segunda etapa, existia entre nós uma alegria em nos dedicarmos ao estudo de um texto dramático. Estávamos sedentos de teatro. Sempre flertamos com o teatro e suas linguagens de atuação, mas nunca de maneira tão explícita, no que diz respeito à sua estrutura dialógica, textual, omitindo intencionalmente o discurso como expressão da cena.

Essa pesquisa tinha sido iniciada com o primeiro espetáculo da Trilogia Influência, o Influência, Primeiros Estudos, que tinha como motivação o cinema de suspense, Alfred Hitchcock e seu filme Corpo que Cai, ou Vertigo. Sua teatralidade, feita no silêncio, na corporeidade do Material ${ }^{54}$ para a Coluna, de Steve Paxton, era o eixo para imagens corpóreas de "quens" (múltiplos personagens construídos e revelados pelo corpo e suas imagens no espaço). As quedas desses corpos de uma plataforma de $2,80 \mathrm{~m}$ de altura, criando clima de mistério, tensão e às vezes inadequação, provocavam drama e riso.

Influência, Primeiros Estudos partia do princípio da atuação e da intervenção que fatos, pessoas, estudos, filmes e encontros exercem sobre nossas vidas. Além de Paxton e seus movimentos espirais da coluna, que nos remetiam ao suspense e que nos levaram ao cinema de Hitchcock, havia minha experiência curtíssima como advogada, mas que plantou em mim a curiosidade sobre os crimes insolúveis. Sempre imaginei fazer um espetáculo que trouxesse conteúdos do Direito para a cena. Em meu imaginário, existia o princípio de um roteiro, trazendo o caso de uma jovem ${ }^{55}$ que, em 1958, ao sair com dois rapazes, se atirava ou era empurrada da cobertura de um edifício em Copacabana. As relações a serem trabalhadas seriam das contradições e das perspectivas dos olhares de cada parte envolvida no caso: da família, da polícia, da imprensa, das testemunhas, da justiça. Com a capacidade corporal dos intérpretes da companhia, adicionando elementos de parkur, matéria de domínio de Diogo Granato, propus que a imagem da queda e suas repetições fossem um de nossos eixos principais. O treinamento foi intenso para a realização dessas quedas, que deveriam ser executadas por todos os intérpretes. Apesar de o assunto ser muito denso, as polaridades entre o

\footnotetext{
${ }^{54}$ Material para a Coluna, sistema desenvolvido por Steve Paxton, é derivado do contato-improvisação, mas não é uma abordagem "improvisacional". É técnico, cuidadoso, lento; explora o uso e a energia dos músculos das costas, articulando a pelve, a coluna, as escápulas; e algumas ideias sobre como os braços e as pernas relacionam-se com esse centro. Inclui pensamentos sobre a prática do Ki e o desenho da forma para segurança no rolamento e outros movimentos.

${ }^{55}$ Aída Curi.
} 
palhaço e o trágico deveriam coexistir, fazendo com que a mesma imagem do corpo em queda pudesse ter múltiplas leituras.

O roteiro desse espetáculo servia como estímulo de contenção e aprendizagem de elementos cênicos, descobertos pelos próprios intérpretes; continha cenas imagéticas para o treinamento das qualidades de movimento dos exercícios do material para a coluna, de contato-improvisação, de composição e de saltos. Apesar de ter escrito pela primeira vez um roteiro, notei que servia apenas como referência, como indicação de possibilidades, não era de forma alguma fixado. As escolhas eram feitas no momento da apresentação pelos intérpretes/criadores e por quem conduzia, criava, a operação de luz naquele dia, no caso, Mauricio Paoli $^{56}$ ou a própria Marisa Bentivegna, nossa iluminadora. Segundo ela:

É essencialmente um exercício de escuta entre operador e intérprete. E diferentemente do que se pode imaginar, não é um trabalho no qual o operador/criador segue os intérpretes em seu livre uso do espaço. $\mathrm{O}$ operador/criador é proponente também, seja no posicionamento de uma cena no espaço, seja editando as imagens, seja provocando um ritmo ou mesmo definindo com a luz o final de um espetáculo...

Nossas construções improvisacionais em Influência, Primeiros Estudos não tinham a preocupação de constituir uma fábula para contar, mas sim buscavam criar diversas situações que nos remetessem ao cinema de suspense; com cenas às vezes associativas e às vezes com novas linhas de situações ou sketches. Tínhamos a liberdade de conscientemente fazer rupturas dessas mesmas linhas e situações. Porém, muitas vezes essas rupturas se davam inconscientemente, como equívoco de escuta ou simplesmente de não escuta. Assim, éramos levados em direção a novas constituições de cenas e situações. Nesse trabalho, o foco não era o estabelecimento de uma linha dramatúrgica linear, as fragmentações eram bem acolhidas. Porém, a pequena temporada no Centro Cultural São Paulo nos instigou a pesquisar como tecer a curvatura de uma trajetória dramática em dança contemporânea improvisacional. Desse modo, nos aproximávamos mais da dramaturgia teatral, desejo antigo de alguns integrantes de nossa companhia. Dirigidos por uma diretora com origens no teatro, seria

${ }^{56}$ Responsável pela assistência de direção conduzia na Cia. Nova Dança 4 em minhas ausências, principalmente em viagens. 
natural a incursão por textos dramáticos, mas os caminhos nos levaram para textos filosóficos, poéticos, biográficos. Agora surgia a oportunidade de estudar e pôr em cena uma peça de teatro, mas tínhamos o entendimento de que, ainda assim, a dança seria nossa linguagem guia e a ela se comporiam as outras linguagens. Aliás, a questão era exatamente essa: articular a dramaturgia do corpo com a dramaturgia teatral. À vista disso, $O$ Beijo no Asfalto foi levado à cena numa releitura subjetiva, delineada no universo da dança de improvisação, como estudo da carpintaria da dramaturgia teatral.

Nos estudos iniciais do espetáculo $O$ Beijo, nossa atenção foi exclusivamente em relação ao texto, leitura de mesa, análise de texto, entendimento das questões principais, leitura palavra por palavra, buscando suas imagens, reconhecer as situações ali propostas, compreender as personagens por aquilo que elas dizem sobre si mesmas e sobre o que as outras personagens dizem delas, principalmente através dos adjetivos, e assim sabermos quem são e como agem. Aqui contávamos com as rubricas do autor, que nos possibilitavam entender como as personagens se sentiam ou se expressavam em suas relações e circunstâncias. Buscávamos nos apropriar do universo de Nelson Rodrigues em $O$ Beijo no Asfalto, seu ritmo de escrita, sua dinâmica, o tipo de vocabulário proposto, mesmo que não fôssemos em cena produzir sequer uma fala emitida pela voz.

Havíamos lido, enquanto procurávamos o texto que instigaria nossa dança, $O$ Vestido de Noiva, também de Nelson. Lemos outros textos, de outros autores como Samuel Beckett, Edgard Alan Poe e François Truffaut. Todavia, O Beijo no Asfalto dinamizaria a nossa contaminação teatral e organizaria os aspectos trabalhados em Influência, Primeiros Estudos, inspirado pelo cinema de suspense. Questões como: morreu acidentalmente? Ou foi assassinado? Ou, ainda, se suicidou? Qual o papel da imprensa? Da polícia? Da sociedade? As visões prismáticas sobre um fato, ou um crime, as testemunhas. Além de agregar temas a serem discutidos, como o papel da mulher, o abuso, o preconceito, o incesto, havia no texto rodriguiano desafios suficientes para verticalizarmos a pesquisa, agora centrada no melodrama, propiciando a inter-relação do texto teatral, na tessitura da dramaturgia do corpo, na dança improvisacional.

A composição do espetáculo a partir de um fio condutor - uma fábula préexistente a ser integrada aos nossos corpos - nos dava liberdade para a construção de uma narrativa. $\mathrm{O}$ enredo e as personagens motivavam e impulsionavam a pesquisa de 
movimento; o desafio estava em construí-los em nossos corpos pelo movimento da dança - uma "dança teatralizada".

Quase concomitante a realização de Influência, Primeiros Estudos, eu havia estudado e dirigido na Escola de Arte Dramática-EAD/ECA/USP dois textos de Beckett, Ato Sem Palavras I e Todos Os Que Caem. Estava impregnada pelo universo becketiano e pela busca de precisão em relação às rubricas. Em Beckett, elas são, na sua maioria, de deslocamento no espaço, de movimento, de repetição, de silêncio e pausa. Havia trazido também esses dois textos para estudo na Cia Nova Dança 4 para o estímulo de precisão e imaginário de suspense. Acredito que essa experiência tenha influenciado minha condução, quando pedi a eles que escolhessem uma personagem e trouxessem três movimentos-síntese, que identificassem aquela personagem escolhida. E se atentassem para as rubricas, pois através delas Nelson Rodrigues revelava sentimentos, humores e estados dessas personagens.

No ensaio seguinte, após toda preparação corporal cotidiana, com respiração Sokushin, Material para Coluna e de muita conversa sobre o texto, fomos para a passagem de características, ou movimentos-síntese das personagens - códigos de movimento, gestos. "Na fase de constituição, as personagens sofreram, assim, um processo de concentração e estilização que lhes conferiu dimensão icônica[...] pela qual um traço sugere a totalidade" - descreveu Silvana Garcia em ensaio sobre $O$ Beijo na revista Folhetim (2010/2011, p. 67). Nosso caminho para a descoberta desses movimentos foi o do "movimento-imagem-ideia", unido aos estudos do texto, trabalhados em laboratórios de movimentos e sensações, buscando desenhos de movimento, nas sensações internas de cada corpo, deixando deflagrar estados, humores e sentimentos que se revelavam ao externo como desenho corpóreo de máscaras - como modelos de comportamento. Olhávamos aqueles corpos e, por já sabermos o texto, já adivinhávamos a personagem apresentada e suas densidades. A sustentação desse mundo interior das sensações sempre foi muito importante em nossa elaboração de dança, ainda mais naquele momento, para que aqueles corpos não se transformassem em desenhos vazios. A questão era conseguir fazer com que aquelas figuras e seus códigos de movimento pudessem também ser lidos por quem não conhecesse a fábula e seus personagens. O objetivo era construir uma terceira via de apreensão do espetáculo, uma obra aberta e independente.

Em $O$ Beijo, os alicerces de nossa estratégia para a condução improvisacional da trama eram os núcleos de situações, as cenas de ambientes, associadas aos códigos de 
movimentos, gestos. Estabelecemos esses núcleos a partir da síntese da estrutura cenográfica, relacionada, como "quadros" por Nelson Rodrigues, para os três atos descritos na peça. Nós os transformamos e os chamamos de arquétipos de situações ou ainda símbolos de relações. Esses modelos eram: a família (casa de Selminha); a delegacia (sala do delegado Cunha); o interrogatório; o escritório da firma (onde trabalha Arandir); a imprensa (o jornal, o jornalista Amado e dona Matilde - portadora da novidade); a rua (acidente, acusação e abuso).

As questões das relações entre espaço público e privado, dimensionados nos quadros, do olhar de dentro, a família, que tem seu espaço privado invadido, pelo o olhar de fora, social, público. A casa como o espaço do drama, ao passo que o jornal e a delegacia são o espaço manipulador. Para articularmos esse tabuleiro, construímos quadros vivos com jogos de composição, inspirados nas partituras de sintonia (tuning scores) de Lisa Nelson. ${ }^{57}$ Essas partituras têm como base a organização do olhar e a utilização dos conceitos da edição de vídeos, como comandos a serem explorados pelos intérpretes criadores no momento da cena, para as construções de composições instantâneas. Esses elementos permitiam que os intérpretes tivessem condições, como editores, de criarem dramaturgia de composição em tempo real, contando e recontando a história, na construção do espetáculo, como explica Cristiano Karnas, intérprete de $O$ Beijo, da Cia. Nova Dança 4:

\footnotetext{
A cada apresentação, como editores/diretores/personagens em cena, podemos cortar, editar, voltar, avançar, repor, substituir, multiplicar, sobrepor, pausar, acelerar, ir mais devagar, etc., por meio dos códigos corporais das personagens, das situações da história, compondo novas montagens do roteiro e do material pré-fixado (códigos de movimento) - Trilogia Revista.
}

O vídeo e o cinema, com suas peculiaridades dramatúrgicas, estavam presentes nessa construção de dança contemporânea inspirada no teatro. Pois o fato de contarmos uma história prescindindo da fala fazia com que buscássemos conceitos diferentes para sua narrativa, fortalecendo nosso interesse pelas intersecções das linguagens.

Rubens Rewald nos trouxe a ideia de tableau, quadros vivos de situações significantes em si, trazendo universalidade na leitura de quem vê. Essa concepção veio

57 Lisa Nelson, americana, atua pelo mundo ministrando workshops, palestras, apresentando. performances. Bailarina, improvisadora, video-grapher, performer e artista colaborativa, participou do movimento revolucionário acontecido em Nova York nos idos anos 1960/1970. É contemporânea de Yvonne Rainer, Nancy Star Smith, Steve Paxton, entre vários outros. 
acompanhada da noção de melodrama clássico, onde há pouco espaço para a ambiguidade: há bons e ruins, mocinhos e vilões. Dessa forma, os tableaux eram imagens instantâneas clássicas que se repetiam em quase todas as peças ou figuras emblema, em que se via, por exemplo, o pai da mocinha morrendo, a mocinha chorando e o pai se aproveitando da situação. Para completar o quadro, uma música dava o andamento, para emocionar. Nelson Rodrigues, apesar de utilizar-se do melodrama, com as tintas do exagero, da paixão, do descontrole, dá contornos de maior complexidade às suas personagens e situações, no aprofundamento da alma humana e do comportamento popular, redimensionado o gênero. Jacó Guinsburg, ao falar do melodrama e do autor, observa:

[...] Porém, nas mãos de Nelson Rodrigues, ele se tornou a forma de moldar no banal, no rotineiro, a exemplaridade trágica da existência humana. O seu teatro o retoma como nenhum outro, na moderna dramaturgia brasileira [...]. (1994, p. 8)

Tentar travar as relações de movimentos por meio dos diálogos e seus conflitos na interação das personagens, como no texto, muitas vezes nos levava à condição mimética de uma construção teatral que não nos favorecia, pois tendia à mímica ou mesmo à pantomima, ou ainda a um estado psicológico que não fazia parte de nossa intenção. Mas nem sempre conseguíamos escapar das armadilhas de "caras e bocas", dramatizando além do que desejávamos, na ânsia de contar a história. Nossa tarefa de dar tridimensionalidade e densidade às personagens pelos códigos de gestos e aos tableaux exigia alternativas de aproximação do texto e transposição para a cena. Tudo deveria ocorrer pelos códigos de movimentos, pausas, angulações, ritmo, tempo, dinâmica, espaço, luz e som. Tendo a dramaturgia da dança como foco, as relações se ofereciam pelos duos, trios e coletivos de dança, que em dado momento propiciavam as situações fotográficas, os tableaux, facilitando a leitura dos acontecimentos. Dessa maneira, fugimos das tentativas da construção dos diálogos e fomos em busca das narrativas do texto. Transformamos diálogos em narrativas.

Figurava na cena de $O$ Beijo, na maioria das vezes, o que o personagem contava e não os diálogos de interação das personagens. Por exemplo, algumas de nossas cenas mais emblemáticas, pelas palavras do próprio Nelson Rodrigues, eram: "o atropelamento de um rapaz, na Praça da Bandeira, o corre pra cá, pra lá. O sujeito estendido, morrendo", trecho contado pelo jornalista Amado ao delegado Cunha. 
Amado continua: "De repente, um outro cara aparece, ajoelha-se no asfalto, ajoelha-se. Apanha a cabeça do atropelado e dá-lhe um beijo na boca”. Essas cenas e seus movimentos decupados eram temáticas, sempre voltavam, se repetiam, com a visão de quem as contava, pois todas as personagens se referiam a elas ao longo do texto, sob perspectivas diferentes. Os desenhos, os gestos, por sua vez, eram os seguintes: um corpo que voa; um corpo estendido no chão; uma mão estendida; um alguém ajoelhado; duas pessoas do mesmo sexo que se beijam na boca. Esses componentes e outros podiam ser realizados em uníssono, solos, duos, em sobreposição a outras cenas, multiplicados em várias angulações e níveis do espaço, criando e editando a dramaturgia de composição.

Esses tableaux também se transformavam em alegorias, como a cena que chamávamos de "imprensa", criada pelos intérpretes numa tarde de ensaio. Foi pedido a eles que trouxessem muitos jornais de casa para fazerem a cena da entrada de dona Matilde, na casa de Selminha, mulher de Arandir, como portadora da novidade - o beijo no asfalto; radiante, com um jornal na mão dona Matilde diz: "O retrato de seu marido, d. Selminha! - indicando o jornal". O código de movimento para a atitude da fofoqueira era apenas uma "dancinha"; "um sambinha miudinho", faceiro e com os jornais em flor, nas mãos, era embalada pela Aquarela do Brasil, de Ari Barroso, em contraponto a atitude perplexa de Selminha. Múltiplas donas Matildes surgiam em composição pelo espaço e seus níveis. Tendo em cena um único intérprete realizando o gestus ${ }^{58}$ de Amado Pinheiro em atitude de regozijo com seus braços e peitos abertos, como o Cristo Redentor, numa dança larga e abrangente, saboreando o poder da difusão da notícia. Essa era a estrutura da cena, mas havia plena liberdade de sua realização. Essas figuras e elementos deveriam aparecer, de preferência sempre; porém, não tínhamos garantias de que isso aconteceria, pois a escuta do momento poderia nos levar a outras escolhas e nos oferecer múltiplas variantes e combinações. Além de toda questão do poder da mídia, do prazer da maledicência, do abuso, buscávamos incluir nesse "sambinha" inocente de dona Matilde aspectos de nossa brasilidade cordial, que busco traduzir nesse parágrafo com o auxílio de Sérgio Buarque de Holanda: “[...] A terminação 'inho', aposta às palavras, serve para nos familiarizar mais com as pessoas ou os objetos e, ao mesmo tempo, para lhes dar relevo [...]" (1986, p. 108).

\footnotetext{
${ }^{58}$ Uma atitude, uma ação física, um gesto social, que oferece a leitura imagética de um todo, revelando características singulares e contraditórias de um personagem. Conceito elaborado por Bertold Brecht, dramaturgo e encenador alemão.
} 
Assistimos, com Rubens Rewald, ao filme O Beijo no Asfalto, de Bruno Barreto de 1980, e nova influência se deu, principalmente na afirmação do tableau e na composição de luz. Marisa Bentivegna trazia os conceitos de preto e branco dos filmes de Hitchcock e seus diretores de fotografia. Nossas primeiras apresentações foram no décimo primeiro andar do Sesc Avenida Paulista, um local que nos obrigava a criatividade, já que seu teto era baixo, havia colunas no meio e janelas para a cidade. Sempre gostei dos desafios de adaptação às arquiteturas espaciais oferecidas, e a Cia. Nova Dança 4 trabalhava muito pouco com cenários. Nossa proposta era, efetivamente, absorver a arquitetura dos lugares a nosso favor e ao mesmo tempo revelar esses espaços. Marisa fez a proposta de utilizarmos o décimo primeiro andar de forma longitudinal, resultando numa grande sala retangular e fazendo o aproveitamento das grandes janelas, que nos revelavam outros prédios de escritórios e, de certos ângulos, conseguíamos até ver as luzes vermelhas e amareladas dos carros que passavam na Avenida Paulista. Ambiente difícil para nossas propostas dramatúrgicas improvisacionais, mas perfeito para retratar a urbanização proposta no texto. Decidimos investigar os modos de melhor aproveitar aquela horizontalidade sustentada por duas colunas, que acabavam por dividir o espaço em três.

Como os personagens principais eram duplicados, ou seja, feitos por dois intérpretes, havia a possibilidade de jogar de forma precisa com o mesmo personagem e de alguma maneira reproduzir os códigos de todos. As figuras arquetípicas ali expostas permitiam que a dança de composição fosse possível. Treinamos a possibilidade de duplicar as cenas, tableaux, nos pontos cegos do espaço. Era mais uma demanda para os intérpretes-criadores-editores em tempo real, assim como para a própria Marisa ou Maurício que fariam a criação e edição de operação do desenho de luz no instante da apresentação. Apesar dos riscos de visibilidade, de sombras e pouca distância entre o teto e o chão, os recortes precisos de luz e o posicionamento dos refletores deram ainda mais a sensação cinematográfica ao nosso $O$ Beijo. Alguns movimentos de luz lembravam travelings, ou mesmo zoons, e valorizavam o figurino do final dos anos 1950, que tinha a coloração Cinemascope. As janelas davam o espaço do interior sendo invadido pelo externo, o persecutório, o perigo que vem de fora, ou o limite da explosão de dentro para fora. Marisa Bentivegna, aos poucos, foi colocando tons pastéis nas gelatinas dos refletores como referência ao filme de Bruno Barreto, e uma citação explícita com um neon vermelho de fora a fora por boa parte da janela do décimo primeiro andar, para que tivéssemos o tableau final do beijo de Aprígio, o pai, em 
Arandir, seu genro agonizante. Naturalmente, toda essa cena, e praticamente o espetáculo todo, era atravessada de música. Afinal, o espetáculo "navegava" no melodrama. Música em sua maioria vinda das trilhas de cinema. Em contraponto ao espetáculo anterior, Influência, Primeiros Estudos, feito em silêncio, sem música.

A pesquisa da Trilogia Influência se caracterizava por ser continuada, um espetáculo contaminando o outro o tempo todo.

As demandas dos intérpretes, músicos e operadores luz, no momento da apresentação, são aquelas da criação em tempo real. Fazer as edições e escolhas dos elementos trabalhados, como um quebra-cabeças. E, dessa forma, oferecer uma história que possa parecer linear, construída na relação entre as dez pessoas que estão em jogo somadas à presença do público, que a tudo altera, apenas por estar ali. A decisão de um muda o rumo das coisas, como já vimos, por isso o fato de sermos um grupo que está junto há muitos anos e se conhece bem, com códigos comuns de aprendizado, de treinamento, constitui um fator favorável para a construção dessa prática improvisacional.

Em $O$ Beijo, todos corroboram para contar uma fábula. No começo de nossas apresentações, em geral, fazíamos o que chamamos de "desfile das personagens". O intérprete que havia pesquisado os códigos de movimento de uma personagem iniciava percorrendo o espaço, indicando ao público que os bailarinos, independentemente de gênero, dariam existência às múltiplas personagens. Todas as mulheres do elenco replicavam os gestos das personagens masculinas, além das femininas e o mesmo acontecia com o elenco masculino. Isso se repetiria com todas as figuras por eles construídas. Trinados de trompetes de Claudio Faria, que caracterizavam algumas dessas personagens, ou ruídos específicos atrelados às histórias que viriam a ser contadas, surgiam como preparação para que o público, ao chegar no teatro, já fosse se familiarizando com o jogo proposto. Essa prática nos servia de aquecimento frente à plateia. Ela era mais interessante quando realizada em espaço longitudinal, pois a ideia era de um desfile, em que os movimentos característicos de um personagem passavam para o corpo de outros intérpretes. Ainda tínhamos a intervenção de Natália ${ }^{59}$ (secretária, DJ e cantora) - uma alusão às cenas de escritório.

Revelar a beleza e os meandros dos teatros faz parte de nossa pesquisa, desde sempre, como exposto na trajetória da Cia. Nova Dança 4. Entrar nos espaços não

\footnotetext{
${ }^{59}$ Mariá Portugal fez a temporada do Sesc Pompeia.
} 
colonizando, mas se adaptando e se tornando parte dele. A intenção é nos amalgamar e valorizar cada detalhe da estrutura que nos acolhe. Foi o nosso objetivo ao tomarmos o palco do Sesc Pompeia e transpor o espaço longitudinal para a expansão da profundidade. $\mathrm{O}$ teatro construído por Lina Bobardi tem duas plateias com cadeiras de madeira maciça de ambos os lados e palco de grandes proporções, tanto de boca de cena como de profundidade. Optamos por uma das plateias voltadas para o público e a outra como extensão do palco, com sua inclinação um tanto íngreme, tendo ao centro a escada de concreto aparente que leva às cadeiras. A iluminação valorizava os volumes e as texturas das fileiras de cadeiras e do concreto, fortalecendo a sensação de urbanidade. No Pompeia perdíamos um pouco o contato com o público, mas ganhávamos na dimensão teatral e trágica da história, diferentemente do que vivíamos no Sesc Avenida Paulista, onde tínhamos uma maior proximidade com o público e uma sensação cinematográfica mais presente. Tanto em um como no outro espaço, a dança se redimensionava, na valorização do texto ao qual dava vida. Como princípio do que entendemos da própria linguagem da improvisação, nos utilizamos das arquiteturas pelas quais passamos.

Fizemos $O$ Beijo em variados lugares, teatros, e sempre com espírito de apropriação dos espaços. Apresentamos, inclusive, ao ar livre, com a sensação de rua e naturalmente as transformações dessa obra aberta se processava.

Então, mais uma vez, o cinema nos levava à dança. No espetáculo Tráfego, a terceira parte da Trilogia Influência, nosso interesse de investigação eram as composições coreográficas cômicas e o retorno à dramaturgia do corpo. Havíamos passado pelo suspense, pelo melodrama, e agora pesquisaríamos o cômico. A intenção era somar alguns elementos apreendidos e conquistados em Influência, Primeiros Estudos e em $O$ Beijo e processá-los na chave do humor.

Apesar de nos utilizarmos do palhaço e da sua comicidade na maioria de nossos trabalhos, esse recurso aparecia mais como suporte do que como linguagem-guia. Nunca havíamos nos debruçado sobre o movimento ou gesto da comicidade para a realização de um espetáculo. Os integrantes da Cia. Nova Dança 4 frequentaram as minhas aulas de palhaço durante os anos de formação, como parte do treinamento da companhia, assim como praticavam o contato e a improvisação nas aulas de Tica Lemos. Nos próprios ensaios e espetáculos, essas linguagens também estavam presentes. 
Começamos a pesquisa assistindo a filmes de Charles Chaplin, Buster Keaton, até chegar a Jaques Tati, e à força de seu sentido coreográfico evidente. Tati, seus filmes, Play Time, de 1967, e Trafic, de 1971, passaram a ser nossa maior referência, mas os palhaços bailarinos Chaplin e Keaton também inspiravam nossos corpos.

Observamos em Tati a realização de um humor sutil, sofisticado, com ironia, com jogos de tempo, contratempo e inadequação cotidiana. A figura de Mr. Hulot, com seu chapéu, capa, cachimbo, óculos e corpo inclinado é exemplar na crítica bemhumorada da vida moderna, do homem perdido diante da arquitetura; por meio de seu olhar o ordinário ganha ares extraordinários.

A composição dos planos cinematográficos nos remete a tableaux de família, de rua, de escritório, de bar, de festa, da sociedade moderna e sua estrutura. Às vezes, Tati parece falar do 'nada' da vida, mas na verdade fala da essência dela e aparentemente de um cotidiano sem grande drama. O que sugere leveza e, ao mesmo tempo, crítica.

Pontos comuns, trabalhados como situações em nossa trilogia, vistos por olhos e gêneros totalmente diferentes, como a crônica social de Nelson Rodrigues e o cotidiano moderno de Jaques Tati, nos levaram a brincar com a estrutura da sociedade e coisas simples do dia a dia: trabalhar, andar pela rua, conviver, se relacionar, dormir, acordar, sonhar. Temas básicos, desses palhaços míticos cinematográficos, os quais nos inspiravam, em Tráfego. Havia ainda pequenos traços de suspense satírico: vestidos com capas longas e chapéus, vultos, surgiam do nada com andares rítmicos de quem ladra, persegue e é perseguido. Brincando com o mistério, realizando um jogo sutil, “de entra e sai", mas com dinâmicas e tempos cômicos. Em uma autocitação que nos rememorava a incursão em Hitchcock.

Os desenhos dos corpos buscavam traços dinâmicos, trabalhando o tempo, o ritmo, o contratempo, de forma precisa favorecendo o estado de inocência que propicia a inadequação à vida. Como sabemos, a linguagem do palhaço é fugidia, perigosa, delicada e pode cair na caricatura facilmente. Devemos estar sempre muito vivos. A prontidão e disponibilidade são palavras bem-vindas, para construção da máscara clownesca. O palhaço como nos mostra Keaton, Chaplin, Tati e outros é um virtuoso, bailarino e acrobata. Nosso treinamento, como acontecia desde Influência, Primeiros Estudos, era constituído, também, de parkour e acrobacias, além do contato e improvisação.

Quando tentava dirigi-los de forma mais pura, indo em direção ao palhaço de cada um, era delicado, difícil, pois os caminhos se divergiam do nosso modelo Jacques 
Tati. Mas o intento era aproximar as duas entidades: 'o palhaço de cada um' a serviço do 'desenho corporal de Tati'. Dessa forma, fomos treinando movimentos decupados do que percebíamos dos estudos que esses três palhaços tinham em comum, e imitando gestos, inclinações e maneirismos de Tati. Colocamos um projetor de cinema na sala de ensaio, maximizamos a tela e literalmente buscávamos imitar, estudar o gestual, o tempo das inclinações que o corpo de Tati fazia, tanto para frente como para trás, ou como abria a porta, girava o corpo, ficava ereto, realizava contratempos ao andar, enfim, queríamos pegar minúcias, nos embebedar delas, vesti-las e ao mesmo tempo revelar suas características clownescas individuais. Em geral, os palhaços tendem aos desenhos das linhas. As sinuosidades não são muito bem-vindas, e, nesse sentido, pensar no desenho ósseo - no movimento dos ossos no espaço oferecendo linhas - nos ajudava muito. A capacidade dos bailarinos de mover esses ossos separadamente provocava estranheza, ao mesmo tempo que revelava a virtuose de cada bailarino na execução de uma graça. O riso não está só no tropeço, no erro, pode estar também no virtuoso, naquilo que só você sabe fazer de maneira especial. Dessa forma, somando as referências dos movimentos daqueles palhaços e o jeito próprio de cada intérprete o fazer, fortalecíamos aspectos universais dos clowns do cinema. Brincávamos em dar foco às estranhezas, às contradições e às idiossincrasias dessas movimentações clownescas que são peculiares a cada palhaço. O modo como o corpo se movia nas situações era a diversão que causava o riso sublinhando o núcleo de cena.

Almejávamos transitar pelos gêneros para melhor compreendê-los e usá-los nos momentos desejáveis e não ser refém deles quando apareciam em momentos improvisacionais, sem que os tivéssemos construído conscientemente.

Com o estudo na trilogia e, acredito, em toda nossa trajetória de Cia. Nova Dança 4, buscamos dar à improvisação a capacidade de construção dramatúrgica do espetáculo, que se reinventava a cada noite diante do público. Usamos de estruturas ou estratégias claras, que se transformavam num jogo de descobertas para quem assistia. Nesse caso, a estrutura era composta por núcleos de situações, as quais podiam ou não entrar numa noite ou em outra, em que podia ou não haver ordem estabelecida e na qual um intérprete devia ou não estar na cena. São escolhas a serem feitas, riscos a serem vividos. Assim, além de dançar, de voar, de construir histórias, de fazer rir, ou emocionar, teríamos o aprendizado maior - tudo é efêmero e passa num instante, se fomos felizes ou não, passou. 


\section{Capítulo V - Ponto de Suspensão: O Reencontro com a Estrutura Pré-Fixada}

\subsection{Ladies, da inocência à crueldade}

Ladies, da inocência à crueldade é um espetáculo que tem como inspiração duas personagens femininas da obra de Wiliam Shakespeare: Lady Macbeth e Ofélia, que, embora não pertençam a um mesmo eixo dramatúrgico, possuem paralelismos de estruturas bastante intrigantes.

Porém, não só na construção dramatúrgica. Os paralelismos são uma opção estética em Ladies, da inocência à crueldade, pois a dança, a palavra, a música, o cenário, os vídeos e a iluminação não são camadas que se absorvem e se diluem, mas que dialogam, se provocam, ora se contrapõem, co-agem, assim como suas duas figuras (personagens, intérpretes), cujas histórias autônomas passam a coexistir e dialogar em cena.

Nesse espetáculo, a orientação era, a princípio, ser mais voltado para a dança, construído através da improvisação, mas com resultado final fechado.

A dança, o teatro, a música como vimos, linguagens muito fortes em minha trajetória de pesquisadora e encenadora- me conduziram ao aprofundament o da busca pela essência da arte no teatro. Assim, o estudo de Shakespeare traduzido em dança me levou a avançar na investigação iniciada em $O$ Beijo, da Cia. Nova Dança 4, e na dramaturgia do teatro. Instigou a dramaturgia do corpo, que interage com as provocações e os estímulos da palavra, das sonoridades no corpo, do espaço da música e dos sistemas do corpo.

A primeira abordagem foi o estudo dos textos como um todo. Lemos Macbeth e Hamlet para entender o universo a que pertencem essas mulheres e $A$ Invenção do Humano, de Harold Bloom, além de comentários e estudos de Barbara Heliodora. 
Dedicamo-nos a ver vídeos, documentários e filmes a respeito das duas histórias: um alimento para a alma e o imaginário, para a construção e apropriação do universo proposto em nós por meio da articulação desses dois textos como modelos de ação.

Ana Noronha faria Ofélia e Gisele Calazans Lady Macbeth. Duas bailarinas afeitas ao trabalho de improvisação: Gisele faz parte da Cia. Nova Dança 4 desde 2002 e Ana já fez alguns trabalhos comigo, como Coppélias?! e O Samba. Ana trabalhou a improvisação na Cia. Silenciosas e em Je T'aime, sob a direção de Diogo Granato, que é integrante da Cia. Nova Dança 4, além de ser bailarina clássica de formação pelo Ballet Cisne Negro.

Como instaurar na dança aspectos tão densos como os vividos por Lady Macbeth e Ofélia? Meus processos sempre se estabelecem a partir da investigação de qual sistema do corpo conduz o intérprete às imagens e sensações vivenciadas pelas personagens, pois não trabalho por meio de caracterização das personagens, mas sim por seu estado de espírito ou por sensações das imagens. É o intérprete quem vive. Não existe a máscara. E nesse caso, em dança, é o movimento quem fala.

São as dramaturgias do corpo, construídas através da consciência corporal, do trabalho com os princípios do BMC (Body Mind Centering) que constituem a base de um movimento orgânico, visceral, sensorial para a descoberta dessas figuras de profundas paixões humanas. O sistema corporal escolhido para narrar as trajetórias trágicas dessas duas figuras de Shakespeare foi o muscular. O deslizar e a explosão muscular certamente trariam o desenho da melíflua, ardilosa e poderosa Lady Macbeth, seja em sua devoção e poder em relação ao marido, seja em sua ambição desmedida, sua invocação do mal, no conluio frio e calculado para um assassinato, na tormenta da culpa e, por fim, na loucura... e no suicídio. Gisele Calazans já havia vivenciado o deslizamento e as explosões musculares na mais recente pesquisa da Cia. Nova Dança 4, quando aprofundamos nossos estudos da dança de contato-improvisação no projeto Nós no Contato, que teve apoio do Programa de Fomento à Pesquisa. A utilização desse sistema era para trabalhar a aproximação e expulsão de outros corpos na dança de contato sem nenhuma proposta dramatúrgica, ou de compreensões de imagens ou sensações, em um trabalho totalmente centrado na improvisação a dois, três, quatro, corpos ou mais em contato constante no coletivo. Em Ladies, ela estaria em solo.

Sim, são dois solos independentes em paralelo, duas forças que convivem e se integram, mas que também podem existir em separado, sem perdas. Nosso desafio: manter a integridade de cada solo, celebrar o inviável diálogo, a provável contradição, a 
impensada intersecção e o inevitável paralelismo entre ambos - e que sejam igualmente potentes.

O sistema muscular também está na construção de Ofélia de Ana Noronha, na sustentação da ponta clássica, que é pura musculatura mesclada à dança contemporânea, danças brasileiras e improvisação, trazendo os códigos do ballet e suas rupturas, para buscar o desenho da inocência, o espírito romântico, a desilusão profunda, o luto, a loucura, o suicídio da jovem Ofélia. A oportunidade de retomar o ballet (técnica de domínio da bailarina Ana Noronha), mais especificamente suas características de suavidade e corporalidade fluida, como uma das técnicas a serem trabalhadas para a personagem Ofélia nos pareceu bem-vinda, acentuando traços como a idealização do amor, a elevação do espírito, a mulher como figura idealizada, etérea, inacessível características encontradas na jovem Ofélia, em seu desenho doce e inocente. A ideia era trazer para a cena os códigos e a técnica clássica, e também sua desconstrução, usando a sapatilha de ponta de outras maneiras, como, por exemplo, ir ao chão, fazer giros muito próximos ao nível do chão, ou dançar praticamente o tempo todo em cima da ponta, de forma não usual no ballet sem perder de vista a visão rel ativa ao corpo, que transita pela dor profunda do luto, do desamor e do estado de loucura. São estados profundos da alma, e para tangenciá-los fizemos uso dos estímulos do BMC aos sistemas do corpo, como os ossos e os órgãos, tendo como foco principal o coração. Adriana Almeida Pees, em sua tese de doutorado Body-Mind Centering e o sentido do movimento em (des)equilíbrio: princípios e técnicas elementares, na criação em dança, pela poética nas linhas dançantes de Paul Klee, traz à tona que:

o método Body-Mind Centering vivencia esses diferentes sistemas sensoriais possibilitando uma ação corporal diferenciada, prepara o corpo para novas demandas. Estas influenciam novos estados mentais e expressivos que, por sua vez, contribuem para outras qualidades de expressão do movimento na dança contemporânea, no qual o intérprete é também criador. Portanto, o BMC é um processo no qual cada um está em contínua transformação. Esse método oferece aos indivíduos possibilidades de escolhas, pautadas no conhecimento experiencial, anatômico e fisiológico das estruturas pertencente aos diversos sistemas corporais. $\mathrm{O}$ processo salienta e cria novas formas de expressão e conexão para consigo mesmo, com o ambiente e com os outros. O método pauta-se num contínuo diálogo entre sensação, sentimento e ação, tríade que permeia também a própria técnica e os princípios. (PEES, 2010, p. 224).

Como já dissemos anteriormente, os paralelismos em Ladies não se limitam às duas personagens femininas de Hamlet e Macbeth. O desejo era desdobrar esse paralelismo também nas linguagens. A dança em paralelo ao teatro; o movimento à 
palavra; a música renascentista, erudita, à música contemporânea; o acústico ao eletrônico. O espaço controlado: palco convencional, cortinas móveis criadas para a cenografia labiríntica palaciana que servem de tela para texturas de vídeo pré-gravadas, mescladas a takes em tempo real para multiplicação do que se vê, assim como solução de visualização do espetáculo.

A palavra de Shakespeare em primeiro lugar inspira o projeto, evoca os paradoxos humanos. A palavra, nesses textos trágicos, é ação dramática, é imagem que afeta o espaço, o movimento, mas é, por si só, literatura. $\mathrm{O}$ desejo de ouvir a palavra por ela mesma, o fluxo da poética shakespeariana; jamais como legenda, mas como jogo, como sonoridade e sentido. A princípio seria em voz off, emitida pelo ator Marat Descartes, que também assina a tradução e a dramaturgia em parceria com a direção.

Logo percebemos que a presença do ator seria fundamental, pois se trata de um jogo vivo em que a sinestesia da palavra afeta os estados, os movimentos e intenções das intérpretes, assim como dos músicos e das outras linguagens em cascata.

Hamlet, Macbeth e outras vozes do texto ditas por este ator à beira do palco, na borda da ação. Recortes dos textos que revelam as duas personagens, seja através de suas próprias falas ou do que outras personagens falam sobre elas.

O começo dos ensaios, práticos, de experimentação do movimento se deram pelo toque firme e contínuo (massagem) na musculatura do corpo, seguido de exploração do movimento de cada uma das bailarinas a partir da sensação do toque, BMC e posteriormente do reconhecimento dessas sensações no imaginário das personagens Ofélia e Lady Macbeth. Durante algum tempo, essa era a dinâmica de ensaio com discussões de trechos das duas peças, somadas a diálogos sobre a humanidade e contradições das personagens e trazendo tudo isso para o acúmulo das experimentações em busca das sensações, imagens e memória do corpo.

Locuções gravadas por Marat também chegavam, como em trechos de Laerte aconselhando Ofélia ou a carta de Macbeth à Lady Macbeth, que resultavam em estímulos e motivações para a pesquisa e construção da dramaturgia do corpo.

Outros sistemas do corpo, como o ósseo, o orgânico e o sanguíneo, também foram explorados através do toque, da massagem e da experimentação da sensação do movimento, da cinestesia, como suporte e, às vezes, como quebra dos padrões das cadeias musculares para que não se mecanizasse o caminho das interpretações de movimentos. Durante todo o tempo, sempre improvisando. O coração, o órgão, foi bastante trabalhado: com o toque das mãos convocando à observação e sensação do 
órgão e tendo a clareza de peso, de volume, de movimento (batimentos cardíacos), instaurando-se o deslocamento e pausas e dando início à dança pela sensação do coração.

Assim, novos caminhos e direções eram apontados para que um arsenal de vocabulários oferecesse vida aos estados e imagens que constituíssem aquelas mulheres trágicas. A questão não era acertar, aprisionar achados, mas sim trazer percepções à tona, repeti-las e libertá-las. Estudos de texto foram feitos, como trabalho de mesa ou decupar cada trecho para preenchimento do imaginário, multiplicação dos pontos de vista para a criação prismática destas figuras. Lady Macbeth não é só má ou ardilosa e nem Ofélia é só romântica e ingênua ou triste. Em um documentário da BBC London, Shakespeare Uncovered - Macbeth with Ethan Hawke, é discutido se o personagem já trazia em si a maldade ou se era um homem comum que foi corrompido. Ou seja, há um mundo a ser explorado, do humano e político, além do sobrenatural que, em Shakespeare, é sempre presente. Não estamos só construindo as personagens, estamos percorrendo as duas tramas e criando o espetáculo através dos corpos.

Quando o teatro entra na dança, a estrutura pede uma lógica. Mas como achar esse empréstimo da lógica na dança sem ser literal? A dança é subjetividade. Se cairmos na narrativa, perderemos. O que é dançar o assombro? É preciso lembrar o subtítulo do projeto, Da inocência à crueldade, e a necessidade de percorrer esse diapasão. Ofélia sofre ações externas, Lady Macbeth provoca as ações, mas a inocência não está somente em Ofélia e nem a crueldade somente em Lady M. A motivação inicial deve sempre ser lembrada: por meio das duas figuras, compreender o humano.

Encontramos muitos movimentos e gestos. Os gestos dialogam com o teatro, objetivos referenciam e organizam o pensamento do espectador. Mas a dança dá a base e o suporte para o gesto. Falando sobre o reflexo e a expressão, Adriana Almeida Pees, em seu artigo O Corpo no Espaço e no tempo pela visão somática (2008, p. 1), afirma que:

a partir da dança Moderna com François Delsarte, um inovador dos princípios, importantes para o BMC no qual o corpo é "mobilizado para a expressão". A obtenção da tensão por contração e relaxamento e possibilidade dos sentimentos estão vinculados a uma performance corporal por meio de gestos. O homem é portador de si mesmo, percussor de sentimento, dando qualidade a elementos espetaculares de saltos, giros e elevação em relação à gravidade. No BMC percebemos, a mobilização de cada sistema corporal para a expressão entre o corpo e a mente, a respiração celular num contínuo expandir e condensar tão primordial no desenvolvimento dos padrões de movimentos básicos e o sentimento como fonte de retroalimentação para uma ação motor. 
Nessa etapa, a dança pede a criação do desenho coreográfico com os movimentos e gestos encontrados. O caminho a ser trilhado é próximo ao processo da Cia. Nova Dança 4 para $O$ Beijo. Um inventário de movimentos, elegendo três ou quatro desenhos do corpo para cada episódio do texto e mais alguns poucos movimentos que determinam as características de ser daquele "quem", daquele esboço de personagem. E com muita liberdade nos "entres" coreográficos de como chegar de um desenho estabelecido a outro. Pois os intérpretes se apropriam do desenho de movimento de todas as personagens para que possam multiplicar esses movimentos no espaço, gerando, uníssonos, outros jogos coreográficos. As questões do espaço coreográfico, das direções e das geometrias do espaço, em Ladies foram, às vezes, resolvidas à maneira teatral de Tadeusz Kantor (2008, p. 334), em seu estudo "O círculo e a linha" - "um personagem faz um círculo. O outro faz qualquer coisa de contrário, que está em oposição ao CIRCULO: A LINHA. - Quando a linha reta se aproxima do circulo, o drama se intensifica". Algumas vezes usei esse recurso, desenhando figuras geométricas com giz no chão ou fita crepe para delimitar espaços e direções, oferecendo clareza de ocupação de territórios de cada personagem, mas ainda deixando livre as danças improvisacionais acionadas por desenhos de movimento e gestos contidos nas descobertas de vocabulário de cada personagem, transitando pelos episódios dos textos. Além de composições, simultaneidades, planos, ritmo, dinâmica, pausas, fluxos, giros, voos, peso, quedas e contraposições de movimentos, o quais constroem a retroalimentação entre a dança e o teatro.

Conforme as imagens e o contexto cênico vão aparecendo, os paralelismos dos textos vão ficando mais presentes e vão fortalecendo o paralelismo coreográfico, a composição. Como o assassinato de Rei Duncan pelo casal Macbeth e a morte de Polônio, pai de Ofélia, assassinado por Hamlet. Ou quando as duas personagens recebem cartas: Macbeth escreve à mulher contando do encontro com as três bruxas que profetizam seu futuro coroamento, enquanto Hamlet manda a carta jurando amor eterno a Ofélia.

Marat traduzia o texto e nos enviava, colocando uma história ao lado da outra, e assim íamos verificando e nos guiando pelas trajetórias. Também íamos selecionando trechos e relacionando-os a gestos e movimentos. Marat comparecia aos ensaios, não cotidianamente, também para o jogo de afecção das palavras de Shakespeare emitidas por ele nos corpos das intérpretes. Vinha com o texto na mão, fazendo leituras de falas 
do texto que tivessem relação com os movimentos ou estados corporais das bailarinas, ou as induzia ao movimento a partir de suas falas, suas entonações e suas nuances de intenções. Provocava, assim, reações corpóreas. A palavra instiga, estimula, induz a ação, evoca movimentos oferecidos pelas imagens das palavras ou pelas intensidades e dinâmicas do dizer, originando deslocamentos, pausas, gestos, articulando criação. Também o corpo em movimento, em diálogo com as palavras, provoca as intenções e alterações das falas, transmutando a racionalidade da palavra em cinestesia.

Havia também a necessidade de uma espécie de prólogo, trazendo o estado de espírito dessas mulheres, anterior ao princípio, às suas dramaturgias: Lady Macbeth, antes de receber a carta do futuro rei, seu marido, como mulher que espera, que ama e é amada; e Ofélia em vivacidade juvenil, aberta, apaixonada até ser devorada pela ambiguidade de Hamlet. Para trazer a tridimensionalidade das personagens, a observação das suas perspectivas, que oferecem leveza a elas, ao menos a princípio. São personagens marcantes da obra de Shakespeare, que entram na história depois da obra começada e se retiram de forma trágica bem antes do fim das tramas, o que nos levou a criar um espetáculo curto, que queima rápido em paixões, como a vida dessas personagens. Dessa forma, a encenação optou por fazer uma curvatura diferenciada, começando o espetáculo em ritmo forte, buscando provocar intensidades nos primeiros dois terços do espetáculo, para depois cair em diluição do movimento, deixando a música, a canção e a palavra em um plano maior, com intensidade, mas suave.

A criação musical é tão forte quanto o movimento e a palavra. Está ali, ocupa o tempo todo com as presenças cênicas marcantes de Mariá Portugal e Ramiro Murilo. Dentro do processo de criação durante os ensaios, eles dinamizavam as construções dramatúrgicas do corpo e do roteiro. Parceiros de algum tempo em outros trabalhos, já afeitos aos meus processos criativos improvisacionais, tanto para espetáculos fechados como abertos em tempo real, entraram com o objetivo inicial de focar cada um na criação musical de uma das personagens. Mariá, com sonoridades percussivas e eletrônicas, traçaria os caminhos de Lady Macbeth, e Ramiro, nas cordas, delinearia a trajetória de Ofélia. É importante lembrar que embora devêssemos pensar em cada solo, trata-se de um duo, ou seja, o paralelismo na música é fundamental. Separadas, têm vida, juntas se completam. A música foi criada trazendo polaridades entre sons acústicos e eletrônicos, entre o universo tonal e melódico, e seu contraponto em ruídos e quebras. 
Os músicos chegavam depois que já havíamos trabalhado e constituído um caminho de pesquisa de movimento e da palavra. Estiveram presentes aos ensaios durante quatro meses, cotidianamente. Em um primeiro momento, foram trabalhando no sentido de tocar o que viam ou sentiam ao vê-las dançarem. A palavra pouco entrava. Era a exploração do movimento e do som, da música. Mariá trouxe a bateria, um instrumento eletrônico e o computador, criando sonoridades não convencionais, música eletroacústica. Ramiro armou seu set de ensaio com violão, guitarra, muitos pedais e mais tarde trouxe um alaúde de dois braços. As criações musicais se davam em sua maioria em sala de ensaio fazendo afecção dos corpos na música e da sonoridade intensa dos instrumentos nos corpos.

A palavra também ia entrando na escuta musical. Primeiro pesquisamos o corpo, depois a palavra, e pouco mais tarde a música. Quando a música entrou, foi preciso um espaço maior para sua descoberta, e foi tomando um volume bastante grande, inclusive literalmente. Todas as vezes que tentávamos fazer ensaios com a música e a palavra, a sonoridade musical se sobrepunha à voz da fala. Assumimos o microfone, que no início modificava a afecção da voz em relação aos corpos, pois a qualidade do microfone de ensaio era muito ruim. Fazer a modulação entre os instrumentos e a voz foi uma negociação. Porém, quando as canções renascentistas entraram, a palavra do texto ganhou cumplicidade com a música. Como se instaurasse o diálogo entre música e palavras em todos os sentidos.

Marat teve que se afastar por questões profissionais e, durante um tempo, as vozes de Shakespeare foram feitas por mim - o que não foi de todo mal, por conhecer bem o texto e poder fazer indicações sobre o modo de leitura, o que certamente contribuiu para a dinâmica e as intenções. Com um direcionamento a partir das palavras do texto, me utilizei das palavras e intenções do texto para oferecer as dinâmicas e intensidades pretendidas. Muito interessante foi observar como as duas intérpretes reagiam favoravelmente aos meus comandos através do texto e o quanto o jogo entre nós se potencializava. A cumplicidade era forte e estávamos a um mês da estreia, momento em que muitas descobertas afloram. O fato de ser uma voz feminina também soou como algo possível, e confesso que meu prazer de atriz se fez presente, mas a encenadora foi mais forte diante de tantas e inúmeras demandas a resolver. Decidimos chamar Otávio Dantas, ator também formado pela Escola de Arte Dramática/EAD/ECA/USP, como Marat, que já fazia parte do projeto por meio dos vídeos e já estava familiarizado com o trabalho: a presença desse ator em cena traria 
para o palco a figura do autor, daquele que vê de fora, interfere e traz o texto também como reminiscência. O livro das duas tragédias está também ao lado dele, junto do banco, com água, sutilmente nos lembrando o livro de cabeceira e o leitor. Signos, sutilezas, como as cortinas que além de revelar o espaço, o castelo, os labirintos, nos remete também à cortina em que Polônio, pai de Ofélia, é assassinado por Hamlet. Aliás, são detalhes que certamente passam despercebidos para muitos, mas que fazem parte das escolhas do que ver, perceber, sentir, vivenciar, experimentar.

Ainda na música, tivemos a presença de Andrea Kaiser, professora de canto da Escola de Arte Dramática/EAD/ECA/USP, pesquisadora das canções de Shakespeare e colaboradora do livro William Shakespeare: as canções originais de cena de Carin Zwlling, que nos revelou o modo de cantar as canções de Ofélia interpretadas por Mariá e Ramiro, abrindo a chave para mais uma forma narrativa e lúdica de contar essas histórias. No texto de Macbeth, não há canções. Mariá e Ramiro se inspiraram e compuseram canções com as palavras dos textos, a partir do original e traduzindo para criar canções que exprimissem o universo de Lady Macbeth. Assim, brotaram canções numa tessitura instrumental, entre a música renascentista, o rock pesado, passando pela música de suspense, o sincopado, o arpejo, o acústico, o distorcido, o melódico e o chiado, os ruídos eletrônicos. Produzindo camadas, sobreposições musicais e narrativas.

A criação do figurino ficou por conta de Larissa Salgado, que também já havia feito figurino para o Tráfico, espetáculo de dança inspirado em Jaques Tati, da Cia. Nova Dança 4. A ideia era usar roupas contemporâneas leves e claras, pois a densidade deveria estar nos corpos, não nas roupas. E que fossem quase traje de passeio, mas que revelasse suas personalidades. O fato de não ser uma roupa de época, que pode distanciar, ajuda a trazer as questões colocadas por Shakespeare sobre a mulher, de uma maneira mais direta aos olhos contemporâneos. Há um pouco de Ofélia em Lady Macbeth e vice-versa. O próprio paralelismo proposto em Ladies oferece essa possibilidade. Há um pequeno detalhe de tecido da roupa floral de Ofélia nos bolsos e em algumas costuras delicadas do vestido branco de Lady Macbeth. Ofélia foi retratada com os motivos florais por sua obsessão - as ervas - e por sua juventude. Lady Macbeth está de branco, pois, após ela e Macbeth terem assassinado Rei Duncan e seus soldados e terem as mãos sujas de sangue, ela diz: - "minhas mãos estão da sua cor, mas eu me 
envergonho por usar um coração tão branco" ${ }^{60}$. Essa é uma das falas, a tradução é literal, e se encontra no texto original.

Ladies, da inocência à crueldade foi concebido primeiramente para o Espaço Cênico do Sesc Pompeia, que, embora seja um espaço alternativo, teve seu posicionamento de arquibancadas posto de maneira convencional nos moldes do palco italiano. Há, porém, uma coluna bem ao centro entre o começo do palco e o começo da arquibancada, que divide o palco da cena, estabelecendo pontos de fuga, ou pontos cegos, e que retira a estabilidade que a sensação de palco italiano propicia. Aliás, muitas vezes o espectador sentava na arquibancada e já se percebia seu mal-estar, pois havia uma coluna em seu campo de visão. Ou seja, desestabilizava a percepção do público e, ao mesmo tempo, tornava seu ponto de vista único, obrigando-o a fazer escolhas e não ser apenas passivo, mesmo estando sentado, sem poder circular. Uma cena que alguém via por completo outros veriam por recortes ou outros prismas, ao vivo ou pelas representações videográficas. Outros relaxavam e ficavam nas percepções sonoras das músicas, canções, texto e luminosidades. Claro que isso também causava, em certa medida, esquizofrenia e desconforto no receptor. Mas essa sensação é também parte da experiência vivida.

A criação cenográfica de Marisa Bentivegna, que também assina a iluminação, multiplicava essa coluna com cortinas brancas transparentes, móveis, da altura do pé direito até o chão, com largura de 1,50 cm. Além disso, havia um piso vermelho-sangue e uma janela real no espaço, bastante grande, com treliças, que dava para a esquina da rua Clélia com Barão do Bananal, o que nos jogava totalmente para o real. Com a possível visualização dos transeuntes, dos faróis dos carros e da passagem do farol vermelho para o verde, por três vezes durante o espetáculo, as bailarinas olhavam para essa janela, nos dando a referência da vida real, nos trazendo, de alguma forma, o espaço entre realidade e ficção.

Essas cortinas serviam, como já foi dito, como tela para os vídeos, com texturas e imagens simbólicas da natureza, reforçando o caráter das personagens ou das circunstâncias vividas. Vídeos feitos por Anna Turra e Otávio Dantas, que, ao fazer as vozes do bardo, na borda do palco, evitava as grandes eloquências e os gestos interpretativos (aliás, a ele foi indicado o não movimento expressivo). Com uma câmera no tripé, ele gravava cenas em tempo real, transpostas e manipuladas pela VJ Anna,

\footnotetext{
${ }^{60}$ Lady Macbeth: "My hands are of your color, but I shame. To wear a heart so white". (Texto original, ato 2 , cena 2, p. 4)
} 
para as cortinas, ou mesmo para as paredes do espaço para dar maior visibilidade às cenas que fossem prejudicadas pela obstrução da coluna. Isso era feito de maneira sutil de modo a não evidenciar apenas tal mecanismo, mas sim trazer mais uma camada de composição vídeo-cenográfica.

Ladies foi concebido originalmente para ser um espetáculo "fechado" e para ser levado a palco, com características mais próximas do palco italiano. Porém, surgiu a oportunidade de fazê-lo de forma aberta em espaço não convencional. Por um dia, apenas. E não tínhamos muito tempo para transição. Como eu e todos os envolvidos já havíamos trabalhado juntos muitas vezes, com espaços alternativos e improvisando em tempo real, em outras ocasiões, aceitamos o desafio. Criamos Ladies explodido. Demos ao espectador a liberdade de transitar pelo espaço, olhar as frestas por vários prismas. $\mathrm{E}$ que fossem capturados por imagens, e que o significado de ação (drama) fosse realmente desempenhado por corpos vivos, diante de corpos vivos, como escreve Rancière. Que o enigma estivesse presente, que o efêmero se apresentasse. Que o espaço fosse multifacetado e resignificado. Cotidiano, real e teatral. Que a instabilidade, a vulnerabilidade e o risco estivessem presentes.

Isso só foi possível com intérpretes com muita vivência, treinamento e experiência improvisacional, para que não houvesse perda da essência construída em Ladies, da inocência à crueldade, já que tudo pode acontecer quando se tem o espectador livre emancipado. E a arte do responder ao momento presente, a improvisação, se faz necessária.

A improvisação existe desde sempre. É vida. Improvisamos todos os dias, mesmo que a vida possua uma rotina, um roteiro a ser cumprido ao longo do dia. Reagimos aos ambientes, às relações, às pressões, aos relaxamentos em respiração. É estar em risco constante, como na vida.

Há muitas maneiras e formas do improvisar. Alguns acreditam que é fazer qualquer coisa às pressas, ou se "virar", onde tudo pode, ou tudo é possível, porque é uma imensa liberdade sem bordas, mas aquilo que não tem limites não se contém, escoa, perde-se. Acredito que, como num jogo, a improvisação no teatro, na dança, deve ter acordos, regras, caminhos, mesmo que seja o vazio. O vazio das ideias préconcebidas, rígidas, pré-fixadas.

O preenchimento da escuta, da disponibilidade, da presença, do espaço, das imagens, das sensações, das imagens de sensações, das ideias inspiradas que nascem em resposta às relações entre tudo o que houver ao redor, princípios básicos no improvisar 
(responder aos estímulos do momento presente; criação). Estamos sujeitos aos êxtases dos grandes instantes criativos e também aos seus esvaziamentos. Viver entre as subidas e decidas dessa experiência intensa é lançar-se em risco no espaço para ser o agente criador e comunicador do movimento, do sentimento, da história, da coreografia imaginada e vivenciada no presente da criação, em comunicação com a plateia cúmplice, e também agente de um momento único e efêmero. Tudo isso requer do intérprete técnica apurada na linguagem, treinamento e disciplina para o que se propõe comunicar. Disponibilidade, sensibilidade, coragem para errar, para se expor, domínio da ansiedade, dos medos, da vaidade, pressupostos a serem trabalhos pelo intérprete em seu caráter, já que na maioria das situações de improviso contemporâneas é o performer quem está presente e não a personagem. Nos idos da commedia dell'arte, tínhamos o oposto, quem estava presente eram as personagens, as máscaras (de desenhos arquetípicos), que jogavam "livremente", improvisando situações e relações com roteiros fixos, os famosos canovaccio.

Absorver novos espaços faz parte do meu universo improvisacional. Busco resolver os desafios sem perdas da essência do trabalho, da peça ou espetáculo a ser apresentado. Não por mera aceitação de todas as condições, jamais. Mas como meio de explorar possibilidades não previstas anteriormente. Exercer a faculdade de adaptação e criar a partir dela.

Expostas essas condições improvisacionais, confiando na maturidade do trabalho e dos artistas envolvidos, usei os teatros laboratórios Alfredo Mesquita (palco elisabetano) e sala Miroel Silveira (palco italiano), além das dependências interiores dos teatros, seus corredores (um espaço pré-existente, com história e cotidiano para muitos de nós alunos da pós-graduação). Os dois teatros têm grandes portas no palco que fazem a intercomunicação entre si através de um corredor com algumas portas, uma delas inclusive com a placa 'gabinete do reitor'. Esse corredor horizontal é cortado por dois outros corredores que dão para o hall de entrada dos dois teatros. No hall, existem quatro portas que dão para os teatros e corredores. Os espectadores escolhem por qual porta entrar, decidem os caminhos para percorrer a aventura da experiência a ser vivida em Ladies explodido.

Mariá estava com sua bateria e set eletroacústico na sala Alfredo Mesquita. Os vídeos pré-gravados, de tessituras da natureza, em figuras geométricas e colorações das próprias bailarinas também eram projetados lá: em uma imensa tela ao fundo do palco. Em oposição estava Ramiro, no outro teatro Miroel Silveira, com seu set de cordas 
sobre um praticável, que fora colocado ali para outro espetáculo e foi absorvido por nós. Atrás de Ramiro, havia outra enorme tela, onde se projetavam as imagens feitas ao vivo pela câmera de Otávio - nossa voz de Shakespeare, que agora andava pelo espaço, também em busca da ação. Lucia, a assistente de direção, segurava os cabos da câmera e do microfone para que ele pudesse dizer o texto e filmar ao mesmo tempo. No entanto, nem ele e nem nenhum de nós sabíamos exatamente onde seriam feitas as cenas. Tínhamos o mapeamento do espaço e possibilidades, jamais a certeza. Ana e Gisele dançavam por todo espaço suas partituras de movimento. Uma luz muito simples feita com poucos recursos foi articulada, naquela ocasião, por nosso operador Fabrício Licursi, que também é bailarino, ator e improvisador. Anna Turra, em um dos corredores, fazia VJ da sala do real e também gravava takes em tempo real. Na sala onde estava Mariá, da plateia a VJ Grissel Pigullem realizava o videomapping das tessituras pré-gravadas. Tudo era cena, espectadores, performers, funcionários que passaram por ali no momento do evento, transeuntes que passavam e davam uma espiada através das portas de vidro dos corredores, das frestas, enfim, instauraram-se múltiplas oportunidades de ponto de vista, explodindo os modos de ver Ladies, da inocência à crueldade. 


\section{Considerações Finais}

Observo que em todos os trabalhos aqui estudados existe o atravessar de uma experiência na outra. Natural, sendo todas as pesquisas coordenadas por uma mesma pessoa, mas às vezes não tão evidente para quem está no trilhar do caminho. Claro que sabemos que usamos um ou outro procedimento semelhante nesta ou naquela criação. Porém, ao transitar pela memória, pelas anotações, percebi a continuidade de pesquisa. Da trilogia das máscaras desenvolvida pela Troupe de Atmosfera Nômade, em que a "língua teatro" se fazia presente: "O ator deveria estar atento às reações corpóreas, aos pensamentos e vice-versa, onde a ação física pudesse suscitar imagens, assim como essas suscita ações. O foco das ações, palavras e pensamentos vinha de um estímulo interno reativo, quase como se o ator criasse uma realidade virtual baseada em si mesmo" "61; ao que mais tarde, na Cia. Nova Dança 4, elaborei como "movimentoimagem-ideia". Proposição essa que oferece aos intérpretes condições de leitura de suas ações, de suas imagens internas, que preencherão, e das imagens externas. Tendo as pausas como grandes aliadas, pois: Existe movimento na pausa; a pausa é movimento; é imagem; e pode gerar ideia.

Devemos lembrar que, quando pausamos, dentro de nós nada pausa, tudo é vivo, nada está congelado, morto, muito ao contrário. Uma pausa requer consciência plena de toda pulsação do corpo. Importante não deixar que a vivacidade se esvaia, e que para isso não nos utilizemos de força e nem aprisionemos a energia. Pois da pausa nascerá o impulso para um novo movimento, no tempo, no contratempo, no espaço. O peso do corpo sustentado pelos ossos, pelo esqueleto, estrutura material clara definida, atraída pela terra, pela gravidade, o aterramento, tudo oferece a oportunidade do intérprete vivenciar a presença cênica.

Os elementos oferecidos são para que aquele que atua na cena possa ser parte atuante da criação, através da improvisação. Porém, isso não impede que o ator ou o bailarino que recebam movimentos, marcações ou intenções externas, da direção, do

\footnotetext{
${ }^{61}$ Pg. 38 desta dissertação.
} 
texto, do coreógrafo, não possam aplicar o "movimento-imagem-ideia" na mesma medida. Nesse caso, há uma imagem prévia a se chegar ou uma intenção desejada a oferecer, assim como uma ideia específica a se concretizar. As questões dos preenchimentos das imagens, suas sensações são do campo da interpretação e podem ser desenvolvidas na repetição. E mesmo na repetição cênica existem microespaços improvisacionais, que são da condição humana: somos diferentes a cada dia e precisamos estar conscientes dessa mudança, o público muda, o meu parceiro também se transforma. Às vezes, são alterações sutis e os que assistem de fora podem não as capturar, mas internamente para quem as vive, essas variações são intensas.

Em Ladies, as intérpretes criaram suas movimentações. Muitas delas são marcadas, coreografadas, outras elas têm maiores liberdades, mas o movimentoimagem-ideia está no fluxo da compreensão de cada instante, e se houver consciência e respiração, haverá comunicação. Isso se transforma em presença continuada, não importa se em estratégias improvisacionais ou se em estruturas pré-fixadas de repetições cênicas ou ainda mistas.

Venho de um momento de transição do teatro no Brasil onde as questões entre o teatro do diretor e do grupo se fundem e as perspectivas são renovadas. Quando chego à dança é no exato instante em que o movimento do intérprete da dança toma corpo próprio e se distingue do corpo do coreógrafo, e as intersecções de linguagens não são mais surpresas, mas sim necessidade e fato.

Os materiais aqui expostos como estruturas de improvisação e de interpretação como o "movimento-imagem-ideia", o "jogo de compêndio", o processo de criação das correlações com as máscaras para desenhos de personagens ou ainda os treinamentos de estados cênicos dos intérpretes, sem caracterização de personagens - são elementos essenciais e constitutivos de meus trabalhos ainda hoje. Porém, a maneira de utilização de cada um deles e a adequação a cada processo são escutas, flexibilidades e novas articulações de mecanismos a serem dispostos conforme os objetivos propostos. Esses conceitos são matéria de estudo e prática de intérpretes da dança e do teatro que comigo trabalharam ou de alunos e companhias que se utilizam desses caminhos para propor suas pesquisas e, a partir delas, constituir novos desenvolvimentos. O princípio dessas formulações é o potencial de autonomia daquele que atua na cena.

Essa dissertação marca a oportunidade de sistematização de alguns de meus procedimentos articulados na esfera dos dois grupos mais longevos em minha trajetória e no âmbito entre a dança e o teatro ou na inter-relação de suas bordas. Essas 
experiências deram frutos e sínteses a outras montagens, estudos e encontros com outros intérpretes criadores, além dos já mencionados neste trabalho. Na maioria dos casos, a diversidade estética dos espetáculos nasce do questionamento de como transitar pelo caminho do intérprete para a criação de um campo de experiência do atuador e do espectador. Identifico minha tendência como diretora, que transita entre múltiplas linguagens e distintos procedimentos, tendendo o olhar para a criação cênica no material humano.

Nos últimos anos, o prazer de contar uma história e de articular vocabulários e ideias por meio das palavras em meus processos tornaram-se foco de pesquisa, na relação das imagens da palavra em sua emissão. A literatura, neste momento, entra em cena traçando imagens através das palavras sustentadas pelo corpo. $\mathrm{O}$ estado corporal é vivo e alerta, porém, cotidiano, menos teatralizado ou dançado. De certa forma, criar imagens por intermédio das palavras sempre esteve em pauta em minhas explorações, quando os textos são emitidos pelos intérpretes. Porém, com os textos literários, à medida que a narrativa se expressa de forma mais acentuada, o intérprete narrador se projeta na cena. A encenação busca preservar ao máximo as palavras do autor, da obra original a ser posta em cena. Não se trata de um respeito excessivo ao texto, mas sim da oportunidade de elaboração de um jogo com as palavras que permita um diálogo entre encenação, intérpretes e obra original. O “jogo de compêndio" é a sustentação para a proposição de outras regras na estrutura de um jogo maior de encenação: como o espaço de supressão de elementos, de repetição de palavras, frases, quebra de linearidade, para o estabelecimento de uma dimensão crítica e de diálogo com o texto em questão. Assim foi feito com montagens como Meu Pai é um Homem Pássaro, da literatura infantojuvenil, do texto homônimo do autor britânico David Almond, em que há uma adaptação de roteiro cênico, mas não das palavras do texto. Macunaíma, o herói sem nenhum caráter, de Mário de Andrade, e Histórias de Alexandre, de Graciliano Ramos, textos clássicos de nossa literatura nacional que foram roteirizados (com as palavras originais de seus autores), com dois coletivos diferentes saídos da Escola de Arte Dramática e que serão apresentados em 2017. No caso desses autores brasileiros, a delicadeza com as palavras ainda é maior pelo fato de terem um vocabulário de imaginário regional peculiar e de serem obras escritas nos anos de 1926 e 1938 respectivamente. Fazer com que essas palavras e imagens nelas contidas se tornem apropriadas e pareçam cotidianas nos dias de hoje, estimulando nosso imaginário e o do espectador, é meu próximo desafio como pesquisadora e diretora. Não há utilização de 
cenários ou elementos externos ao recurso da emissão da palavra sustentada pelo corpo que produz imagens sutis. A música e os instrumentos acústicos são acessórios bemvindos, já que "contamos a história cantando e cantamos a história contando", um experimento que faz parte do jogo da palavra. A ideia é que o espectador seja estimulado a ver tudo o que se passa no contexto daquela obra com pouquíssimos elementos.

O prazer de dizer, de escutar e imaginar palavras. Essas montagens buscam o aconchego e a intimidade sem ser interativo, com o sentido de estar junto, na passagem do tempo da encenação e na aproximação entre espectador e atuante. Nesses tempos virtuais, acredito na importância da presença diante do outro, e as artes cênicas nos oferecem essa oportunidade e risco de um corpo presente, vibrante frente a outro contando histórias, questionando certezas e pensamentos por meio do lúdico e da imaginação. Tendo o movimento-imagem-ideia como estrutura de sustentação, agora em desenhos mais sutis e subliminares, corroborando para o fortalecimento da emissão da palavra, de suas imagens e infinitas matizes. 


\section{Bibliografia}

ABENSOUR, Gérard, Vsévolod Meirhold ou a Invenção da encenação. Trad. J. Guinburg. São Paulo: Ed. Perspectiva, 2011.

ABREU, Luis Alberto de. Doze passos de um processo de criação. Cadernos da ELT - Escola Livre de Teatro. Santo André, v.2, n.1, jun., 2004. Disponível em: $<$ http://www.sesipr.org.br/nucleodedramaturgia/>. Acesso em: 6 de setembro de 2016

ACHATKIN, Vera Cecilia O Teatro-Esporte de Keith Johnstone: o ator, a criação e o público. São Paulo, 2010. Tese (Doutorado) - Departamento de Artes Cênicas/Escola de Comunicações e Artes/USP.

ANSALDI, Marilena. Atos - Movimentos na Vida e no Palco. . São Paulo: Ed. Maltese, 1994.

BACHElARD, Gaston. A Poética do Espaço. Trad. Antônio de Paula Danesi. São Paulo: Ed. Martins Fontes, 2000.

BARROS, Manuel. Poesia Completa. São Paulo: Leya, 2010.

BROOK, Peter. Avec Grotowski. Trad. Celina Sodré e Raphael Andrade. Rio de Janeiro: Dulcina Editora, 2011.

BENJAMIN, Walter. Reflexões sobre a criança, o brinquedo e a educação. São Paulo: Editora 34, 2009.

CARRIÈRE, Jean Claude. A Linguagem Secreta do Cinema. Trad. Fernando Albagli e Benjamin Albagli. 1. Ed. Especial. Rio de Janeiro: Nova Fronteira, 2006 (40 anos, 40 livros)

CHACRA, Sandra. Natureza e sentido da improvisação teatral. São Paulo: Perspectiva, 2005.

DAMÁSIO, António. O Mistério da Consciência: do corpo e das emoções ao conhecimento de si. Tradução de Laura Teixeira Motta. São Paulo: Companhia das Letras, 2000. 
DARTON, Robert. O Beijo de Laourette: mídia, cultura e revolução. Trad. Denise Bottmann. São Paulo: Companhia das Letras, 2010.

DELEUZE. G. Espinosa e a filosofia prática. Tradução de Daniel Lins e Fabien Pascal Lins. São Paulo: Escuta, 2002.

DELEUZE, Gilles; GUATARRI, F. Mil Platôs. São Paulo: Editora 34, 1996, v. 3.

-

FELLINI, Frederico. Fellini por Fellini. $3^{\circ}$ ed. Trad. José Antonio Pinheiro Machado, Paulo Hecker Filho e Zilá Bernd. Porto alegre: L\&PM, 1986.

FÉRAL, Josette. Além dos limites: teoria e prática do teatro. Trad. J. Guinsburg. 1.ed. São Paulo: Perspectiva, 2015.

FERRACINI, Renato. A arte de não interpretar como poesia corpórea do ator: Campinas: Editora da Unicamp/Imprensa Oficial do Estado S.A., 2001.

FO, Dario. Manual mínimo do ator. São Paulo: Editora Senac, 1998.

GARCIA, Silvana. Especial Nelson Rodrigues. Revista Folhetim. Rio de Janeiro, Teatro do Pequeno Gesto, n. 29,2010/2011, p. 62-75.

GAULIER, Philippe. O Atormentador: minhas ideias sobre teatro. Trad. Marcelo Gomes. São Paulo: Edições Sesc, 2016.

GROTOWSKI, Jerzy. O Teatro Laboratório de Jerzy Grotowski 1959-1969. Tradução para o português de Berenice Raulino. São Paulo: Edições Sesc SP; Pontedera, IT: Fondazione Pontedera Teatro, 2010.

GUINSBURG, Jacó. Travessia - Revista De Literatura Brasileira, n. 28, UFSC, Florianópolis, $1^{\circ}$ semestre de 1994, p. 7-10.

HOLANDA, Sergio Buarque de. Raízes do Brasil 18 ed. Rio de Janeiro: José Olympio, 1986.

IDEOKINÉSIS Disponível em: <http://www.ideokinesis.com/dancegen/dowd/dowd.

htmh>. Acesso em: set. 2016;

JANÔ, Antôni Januzlli. A Aprendizagem do ator. São Paulo: Ática, 1992.

KANTOR, Tadeusz. Liçoes de Milão, no limiar do desconhecido - reflexões sobre o objeto no teatro de Tadeus Kantor. Trad. Wagner Francisco Araujo Cintra (feita a partir da versão francesa ACTES SUD - PAPIERS, Paris, 1990), 2008.

KOBIALKA, M. A journey through other spaces. Essays and manifestos, 1944- 
1990 - Tadeusz Kantor. Los Angeles: University of California Press, 1993, p. 208265.

KOUDELA, Dormien Koudela. Texto e Jogo: uma didática brechtiana. São Paulo: Perspectiva, 2010 (Debates 271/ dirigida por J. Guinsburg).

MACARI, Maria Carolina. Tiros de movimento-imagem: estudo de um processo artístico e pedagógico de Cristiane Paoli Quito. São Paulo, 2011. Dissertação (Mestrado) - Unesp.

MACHADO, Maria Ângela de Ambrosis Pinheiro. Cartografia do conhecimento artístico: o processo de criação do ator. São Paulo, 2000. Dissertação (Mestrado em Comunicação e Semiótica) - Pontifícia Universidade Católica de São Paulo.

- Uma nova mídia em cena: corpo, comunicação e clown. São Paulo, 2005. Tese (Doutorado) - Pontifícia Universidade Católica.

MUNIZ, Mariana Lima; MIGUEL, Diogo Horta. A Improvisação no processo artístico e pedagógico de criação do espetáculo Fábulas Errantes - Galpão Cine Horto. Belo Horizonte: Escola de Belas Artes/UFMG, 2013.

NICHOLS, Sallie. Jung e o Tarô: uma jornada arquetípica. Trad. Octávio Mendes Cajado. São Paulo: Cultrix, 2007.

OIDA, Yoshi. O ator invisível. São Paulo: Beca, 2001.

PAVIS, Patrice. Dicionário de Teatro. São Paulo: Ed. Perspectiva, 1999.

PEES, Adriana Almeida. Body-Mind Centering ${ }^{\circledR}$ e o sentido do movimento em (des)equilíbrio: princípios e técnicas elementares, na criação em dança, pela póestica nas linhas dançantes de Paul Klee. Campinas, 2010. Tese (Doutotado) Universidade Estadual de Campinas. Instituto de Artes.

O Corpo no Espaço e no tempo pela visão somática Anais do V Congresso, Pesquisa em Dança no Brasil: Processos e investigações, 2008.

PEREIRA, João Frayse. O que é Loucura. São Paulo: Brasiliense, 1984.

RANCIÈRE, Jacques. O Espectador Emancipado. São Paulo: Martins Fontes: São Paulo, 2012.

REWALD, Rubens. Caos/Dramaturgia. São Paulo: Perspectiva/Fapesp, 2005.

SCALA, Flaminio. A Loucura de Isabella e outras Comédias da Commedia dell'arte. Organizado e traduzido por Roberta Barni. São Paulo: Iluminuras, 2003. 